\title{
ANTRACNOSE DO FEIJOEIRO: QUANTIFICAÇÃO DE DANOS E EFEITO DO TRIFENIL ACETATO DE ESTANHO NO CRESCIMENTO DO HOSPEDEIRO E NO PROGRESSO DA DOENÇA
}

\author{
LEONARDo GIANASI \\ Engenheiro Agrônomo
}

Orientador: Prof. Dr. ARMANDO BERGAMIN FILHO

Tese apresentada à Escola Superior de Agricultura

"Luiz de Queiroz", Universidade de São Paulo, para obtenção do título de Doutor em Agronomia, Área de Concentração: Fitopatologia.

PIR A C I C A B A

Estado de São Paulo - Brasil

Março - 1999 
Dados Internacionais de Catalogação na Publicação (CIP) DIVISĀO dE BIBLIOTECA E DOCUMENTAÇĀo - Campus "Luiz de Queiroz"/USP

Gianasi, Leonardo

Antracnose do feijoeiro: quantificaçāo de danos e efeito do trifenil acetato de estanho no crescimento do hospedeiro e no progresso da doença / Leonardo Gianasi. - Piracicaba, 1999.

$120 \mathrm{p}$.

Tese (doutorado) - Escola Superior de Agricultura Luiz de Queiroz, 1999. Bibliografia.

1. Antracnose-do-feiloeiro 2. Controle quimico 3. Dano 4. Epidemiologia 5. Feijão carioca 6. Fitopatologia 7. Fungicida 8. Produção agrícola 9. Sensioramento remoto I. Titulo

CDD 635.652

Preruitida a copia to tol ou parcial feste documento $\%$ Autor? 


\section{AGRADECIMENTOS}

Ao Prof. Dr. Armando Bergamin Filho, pela orientação e apoio constantes. À Profa. Dr ${ }^{\mathrm{a}}$. Lilian Amorim, pela co-orientação e sugestões apresentadas. Ao Prof. Dr. Tasso Leo Krugner, pela revisão do Summary.

Ao CNPq, pelo auxílio financeiro na concessão da bolsa de estudos.

A Hokko do Brasil Indústria Química e Agropecuária Ltda., pelo total apoio na condução dos experimentos, especialmente aos Engenheiros Agrônomos Eros Molina Ochiena, Francisco Hotta, Jorge Tsutomu Hassuike, Isokasu Kon, Luiz Gustavo Gonella; aos Técnicos Agrícolas, Alcindo Galvão, Ailton Silva, Dorival Buoer Júnior e a todos os funcionários da Estação Experimental Nova Fazenda Hokko.

Aos colegas da Fitopatologia: Adriana, Anésio, Cláudia, Cecília, Célia, Célia Malvas, Fabiana, Flávia, Hélio, Heloísa, João, José Renato, Leila, Luciana, Marise, Nelson, Regina, Renato, Solange, Zilton; às estagiárias e amigas Nilcelí Fernandes, Lídia de Souza, Maria Elisa Basso, Renata Rodrigues e Sílvia Afosenca Lourenço; ao Seu Pedro, Marina, Jeferson, Edivaldo; todos os professores e alunos de pós-graduação que colaboraram para a alegre e estimulante convivência no Departamento de Fitopatologia da ESALQ/USP

À minha noiva, Maria de Lourdes Oliveira Silva, pelo auxílio, apoio e incentivo constantes que em muito influenciaram a conclusão deste trabalho.

À Empresa de Pesquisa Agropecuária de Minas Gerais - EPAMIG, pela liberação parcial de minhas atividades para conclusão deste trabalho. 


\section{SUMÁRIO}

Página

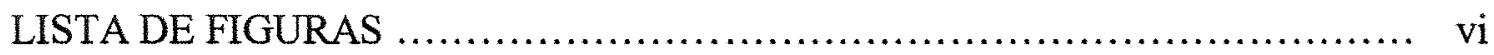

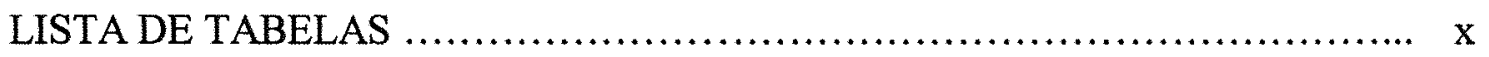

LISTA DE SIGLAS, ABREVIATURAS E SÍMBOLOS ...................... xii

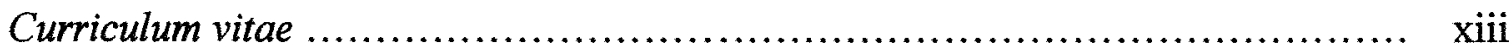

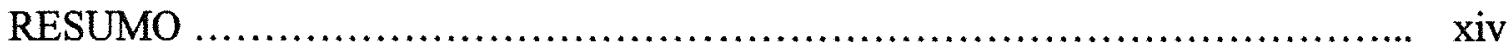

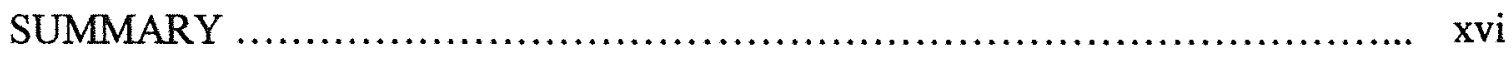

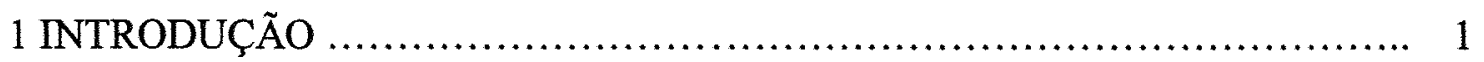

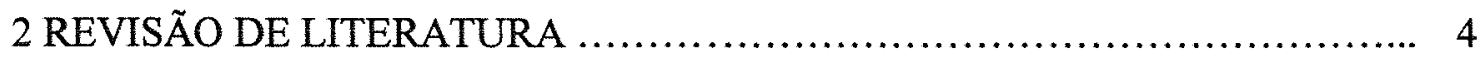

2.1 A Antracnose do feijoeiro .......................................................................... 4

2.1.1 Etiologia e morfologia ..................................................................... 4

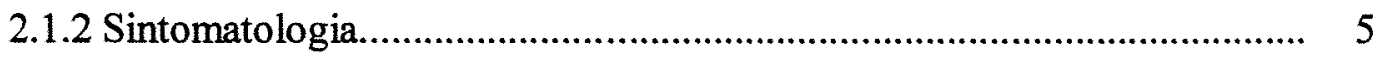

2.1.3 Ocorrência e importância..................................................................... 6

2.1.4 Epidemiologia e ciclo da doença............................................................ 7

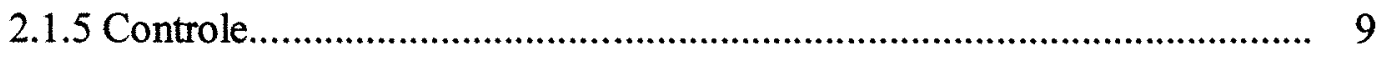

2.2 Avaliação de danos........................................................................... 10

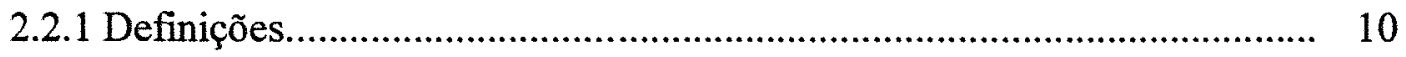

2.2.2 Quantificação de doenças................................................................ 12

2.2.3 Metodologia para quantificação de danos............................................. 13

2.2.4 Modelos para estimativa de danos...................................................... 14

2.2.5 Avaliação de danos por meio da área foliar fotosintetizante.................... 16

2.3 Manejo integrado de doenças................................................................... 19

2.3.1 HAD, HAA e o limiar de dano econômico................................................ 21

2.4 Sensoriamento remoto........................................................................ 24

3 ANTRACNOSE DO FEIJOEIRO: RELAÇÃO ENTRE DOENÇA, ÁREA FOLIAR SADIA E PRODUÇÃO.............................................................. 27

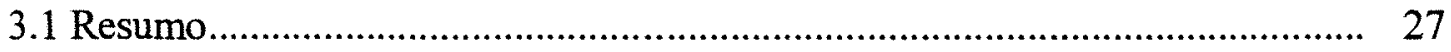




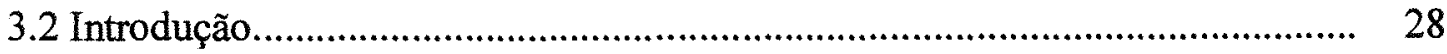

3.3 Material e métodos......................................................................... 31

3.3.1 Experimentos de campo ........................................................................ 31

3.3.2 Crescimento do hospedeiro, severidade de doença e produção................ 32

3.3.3 Variáveis integrais............................................................................. 33

3.3.4 Análise dos dados.......................................................................... 34

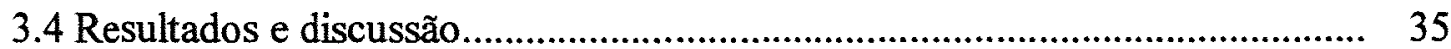

3.4.1 Radiação solar doença e produção............................................................. 35

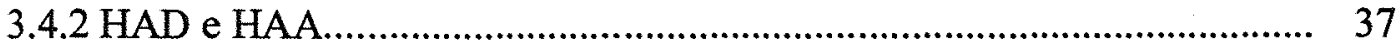

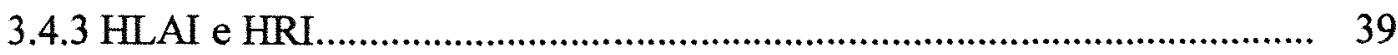

4 ANTRACNOSE DO FEIJOEIRO: RELAÇÕES ENTRE SEVERIDADE, DESFOLHA ÁREA FOLIAR E MEDIDAS DE REFLETÂNCIA..................... 50

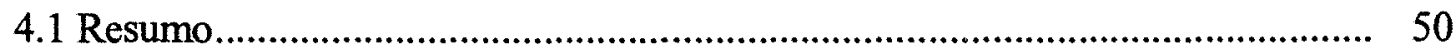

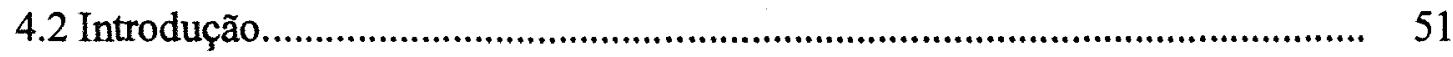

4.3 Material e métodos................................................................................. 54

4.3.1 Experimentos de campo.................................................................... 54

4.3.2 Crescimento do hospedeiro, severidade de doença e produção................ 55

4.3.3 Variáveis integrais........................................................................ 57

4.3.4 Medidas de refletância.................................................................... 58

4.3.5 Análise de dados.............................................................................. 59

4.4 Resultados e discussão........................................................................ 59

4.4.1 Comportamento do índice de área foliar, severidade de antracnose e refletância durante o ciclo da cultura....................................................... 59

4.4.2 Relações entre severidade de doença, desfolha e refletância.................... 63

4.4.3 Relações entre refletância e variáveis de área foliar.................................. 64

4.4.4 Modelo para estimar HLAI.................................................................. 67

4.4.5 Relações da produção com variáveis de área foliar, doença e

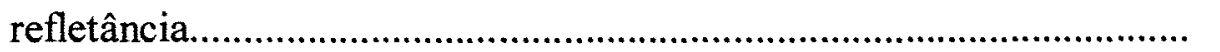


4.4.6 Sensibilidade de medidas de refletância para verificar a eficiência dos tratamentos

5 ANTRACNOSE DO FEIJOEIRO: EFEITO DO TRIFENIL ACETATO DE ESTANHO NO CRESCIMENTO DO HOSPEDEIRO E NO PROGRESSO DA DOENÇA 76

5.1 Resumo 76

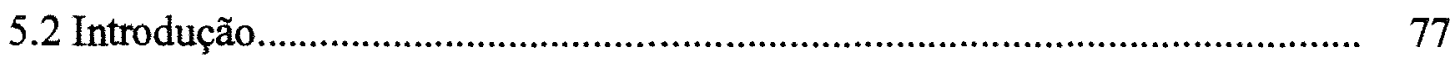

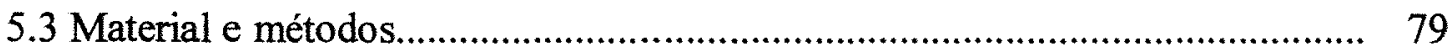

5.3.1 Experimentos em casa de vegetação......................................................... 79

5.3.2 Experimentos de campo .................................................................. 80

5.3.3 Crescimento do hospedeiro, severidade de doença e produção................ 82

5.3.4 Variáveis integrais.............................................................................. 83

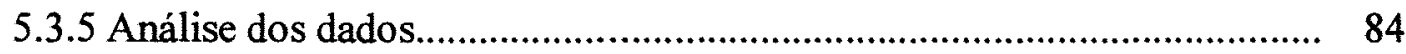

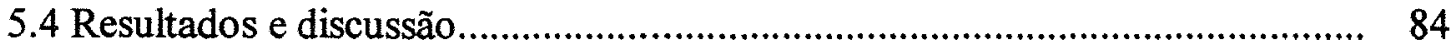

5.4.1 Experimentos em casa de vegetação..................................................... 84

5.4.2 Experimentos de campo................................................................ 87

5.4.2.1 Severidade de doença, desfolha e AUDPC..................................... 87

5.4.2.2 LAI, HLAI e HRI.......................................................................... 91

5.4.2.3 HAD, HAA e produção................................................................. 93

5.4.2.4 Limiar de dano econômico................................................................... 97

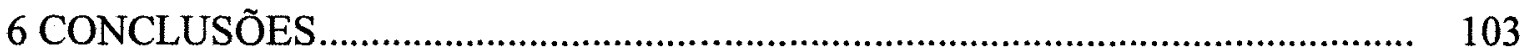

REFERÊNCIAS BIBLIOGRÁFICAS............................................................. 105 


\section{LISTA DE FIGURAS}

Página

1 Produção $\left(\mathrm{g}_{\text {planta }}{ }^{-1}\right.$ ) versus área sob a curva de progresso de doença, para plantas individuais de feijão infectadas com antracnose em três experimentos (60 plantas por experimento), conduzidos em Pereiras, SP, 1997. Círculos cheios representam avaliações onde foi considerada desfolha promovida pelo patógeno para cálculo da AUDPC. Círculos vazios representam avaliações onde não se considerou desfolha.

2 Produção $\left(\mathrm{g}_{\text {planta }}{ }^{-1}\right)$ versus desfolha, para plantas individuais de feijão infectadas com antracnose em três experimentos $(60$ plantas por experimento), conduzidos em Pereiras, SP, 1997.

3 Produção versus duração da área foliar sadia (HAD, dias) e absorção da área foliar sadia (HAA, $\mathrm{MJ} \mathrm{m}^{-2}$ ) para plantas de feijão infectadas com antracnose, em três experimentos conduzidos em Pereiras, SP, 1997. Reta obtida por meio da análise conjunta dos dados dos três experimentos.

4 Coeficientes angulares obtidos pela regressão linear, com passagem forçada pela origem, de produção ( $\mathrm{g}$ planta ${ }^{-1}$ ) com índice de área foliar sadia (HLAI), e radiação interceptada pela área foliar sadia por unidade de tempo (HRI, MJ $\mathrm{m}^{-2}$ ), medidos nos estádios de crescimento de feijoeiros infectados com antracnose, em três experimentos conduzidos em Pereiras, SP, 1997. As linhas representam a função beta ajustada aos dados. Para maiores detalhes veja texto. Estádios de crescimento: $V_{3}=$ primeira folha trifoliolada; $V_{4}=$ terceira folha trifoliolada; $R_{5}=$ pré florescimento; $R_{6}=$ florescimento; $R_{7}=$ formação das vagens; $R_{8}=$ enchimento das vagens e $R_{9}=$ maturidade fisiológica.

5 Coeficientes angulares obtidos pela regressão linear, com passagem forçada pela origem, de produção (g planta ${ }^{-1}$ ) com índice de área foliar sadia (HLAI), e radiação interceptada pela área foliar sadia por unidade de tempo (HRI, MJ 
$\mathrm{m}^{-2}$ ), medidos nos estádios de crescimento de feijoeiros infectados com antracnose, em três experimentos conduzidos em Pereiras, SP, 1997. No campo 5 foram considerados apenas os estádios $R_{6}-R_{9}$. Para maiores detalhes veja texto. Estádios de crescimento: $V_{3}=$ primeira folha trifoliolada; $\mathrm{V}_{4}=$ terceira folha trifoliolada; $\mathrm{R}_{5}=$ pré florescimento; $\mathrm{R}_{6}=$ florescimento; $R_{7}=$ formação das vagens; $R_{8}=$ enchimento das vagens e $R_{9}=$ maturidade fisiológica.

6 Severidade de antracnose, índice de área foliar ( $L A I)$ e refletância em $810 \mathrm{~nm}$ $\left(R_{810}\right)$ observados em feijoeiro cultivar Carioca, em três épocas de plantio, em parcelas com (círculos cheios) e sem (círculos vazios) controle da doença. Para severidade e LAI cada ponto representa a média para 12 plantas. Para refletância, cada ponto representa a média de 12 amostragens....

7 Severidade de antracnose versus refletância, representada pela diferença normalizada $\left(N D_{810,610}\right)$ utilizando os comprimentos de onda 810 e $610 \mathrm{~nm}$, observadas para copa de feijoeiro com índice de área foliar superior a 3,6. A reta representa a equação ajustada: $y=0,8909-0,0042 * x, R^{2}=71,38 \% \ldots \ldots$

8 Modelo para estimativa do índice de área foliar sadia (HLAl) em função da refletância no comprimento de onda de $810 \mathrm{~nm}$

9 Relações da produção, g parcela ${ }^{-1}\left(6 \mathrm{~m}^{2}\right)$, com duração de área foliar sadia (HAD), absorção de área foliar sadia (HAA), área sob a curva de progresso da doença (AUDPC), integral da refletância em 610, 760 e 810 nm (AUR 610 , $\mathrm{AUR}_{760}$ e AUR 810 )

10 Progresso da área foliar do feijoeiro em duas épocas de plantio. Círculos cheios representam o tratamento com aplicação semanal de fungicida. Círculos vazios representam o tratamento testemunha. As Barras verticais representam a diferença mínima significativa $(\mathrm{P}<0,05)$ para comparação dos tratamentos em cada avaliação. $O$ início das pulverizações deu-se aos 20 e 37 dias após o plantio para as épocas 1 e 2 , respectivamente 
11 Curva de progresso da severidade de doença e desfolha promovida pela antracnose do feijoeiro, para os campos 5,6 e 7 . As setas pontilhadas representam a época de inoculação do campo. As setas cheias representam o estádio de crescimento $R_{5}$ (Michaels, 1994). Tratamento 1 - pulverizações semanais iniciadas 7 dias após a inoculação. Tratamento 2 - pulverizações no estádio $R_{5}$ e 14 dias após. Tratamento 3 - pulverização no estádio $R_{5}$. Tratamento 4 - testemunha..

12 Índice de área foliar (LAI), e índice de área foliar sadio (HLAI), para os campos 5, 6 e 7. As setas pontilhadas representam a época de inoculação do campo. As setas cheias representam o estádio de crescimento $\mathrm{R}_{5}$ (Michaels, 1994). Tratamento 1 - pulverizações semanais iniciadas 7 dias após a inoculação. Tratamento 2 - pulverizações no estádio $R_{5}$ e 14 dias após. Tratamento 3 - pulverização no estádio $R_{5}$. Tratamento 4 testemunha.

13 Radiação interceptada pela área foliar sadia por unidade de tempo, do feijoeiro, para os campos 5,6 e 7. As setas pontilhadas representam a época de inoculação do campo. As setas cheias representam o estádio de crescimento $R_{5}$ (Michaels, 1994). Tratamento 1 - pulverizações semanais iniciadas 7 dias após a inoculação. Tratamento 2 - pulverizações no estádio $R_{5}$ e 14 dias após. Tratamento 3 - pulverização no estádio $R_{5}$. Tratamento 4 - testemunha.

14 Duração da área foliar sadia, HAD (dias), absorção da área foliar sadia, HAA (MJ m${ }^{-2}$ ) e produção $\left(g\right.$ planta $^{-1}$ ) para os campos 5, 6 e 7 do patossistema feijão antracnose. Tratamento 1 - pulverizações semanais iniciadas 7 dias após a inoculação. Tratamento 2 - pulverizações no estádio $R_{5}$ e 14 dias após. Tratamento 3 - pulverização no estádio $R_{5}$. Tratamento 4 - testemunha. Barras representam o erro padrão da amostra. Barras seguidas de mesma letra não diferem estatisticamente entre si (Tukey, $\mathrm{P}<0,05$ ). 
15 Radiação interceptada pela área foliar sadia por unidade de tempo, do feijoeiro, para os campos 5, 6 e 7. As setas cheias representam o estádio de crescimento $\mathrm{R}_{5}$ (Michaels, 1994). Círculos cheios representam o tratamento 1, parcela controle. Círculos vazios representam o tratamento 4,

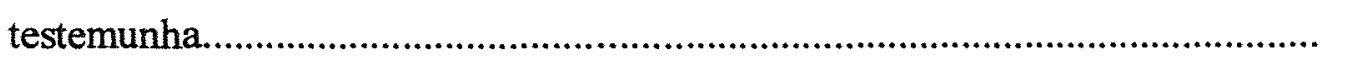




\section{LISTA DE TABELAS}

Página

1 Radiação solar, severidade de antracnose do feijoeiro, área sob a curva de progresso de doença (AUDPC) e produção para três experimentos* conduzidos em Pereiras, SP, 1997.

2 Varáveis $b_{1}$ e $b_{2}$ para o modelo exponencial ( $Y=b_{1} \exp \left(b_{2}\right.$ AUDPC)), obtido entre produção ( $\mathrm{g}$ planta $^{-1}$ ) e AUDPC, para feijoeiros infectados com antracnose, em três experimentos. Os modelos foram ajustados considerando-se ou não a desfolha promovida pelo patógeno, em três experimentos conduzidos em Pereiras, SP, 1997

3 Valores de interseção e coeficientes angulares ( \pm erro padrão) das retas de regressão entre produção (g planta $\left.{ }^{-1}\right)$ e duração da área foliar sadia (HAD, dias) e entre produção e absorção da área foliar sadia (HAA, $\mathrm{MJ} \mathrm{m}^{-2}$ ) em três experimentos conduzidos em Pereiras, SP, 1997

4 Coeficientes angulares ( \pm erro padrão) das retas de regressão (passagem forçada através da origem) entre produção $\left(\mathrm{g}_{\text {planta }}{ }^{-1}\right)$ e índice de área foliar sadia (HLAI) e entre produção e radiação interceptada pela área foliar sadia por unidade de tempo (HRI, $\mathrm{MJ} \mathrm{m}^{-2}$ ), em diferentes estádios de crescimento do feijoeiro, em três experimentos conduzidos em Pereiras, SP, 1997

5 Parâmetros estimados e coeficiente de determinação $\left(R^{2}\right)$ do modelo linear $\left(\mathrm{Y}=\mathrm{A}+\mathrm{B}^{*} \mathrm{X}\right)$ ajustado aos valores de refletância, variável dependente, plotados contra o índice de área foliar, LAI, índice de área foliar sadio, HLAI, e absorção de área foliar sadia por unidade de tempo, HRI, para os campo 5,6 e 7 .

6 Absorção de área foliar sadia (HAA), área sob a curva de progresso de antracnose (AUDPC), área sob a curva de refletância na faixa de $810 \mathrm{~nm}$ $\left(A U R_{810}\right)$ e produtividade de feijoeiro, observadas para três épocas plantio..... 
7 Área sob a curva de progresso da área foliar, AULAPC, do feijoeiro e produção, $g$ planta $^{-1}$, para dois experimentos realizados em casa de vegetação.

8 Área sob a curva de progresso da doença, AUDPC, para antracnose do feijoeiro, para três experimentos realizados em condições de campo. Tratamento 1 - pulverizações semanais iniciadas 7 dias após a inoculação. Tratamento 2 - pulverizações no estádio $R_{5}$ (Michaels, 1994) e 14 dias após. Tratamento 3 - pulverização no estádio $R_{5}$. Tratamento 4 testemunha. 


\section{LISTA DE SIGLAS, ABREVIATURAS E SÍMBOLOS}

AUDPC: $\quad$ área sob a curva de progresso da doença (Area Under Disease Progress Curve).

AUR: integral da curva de medidas de refletância em determinado comprimento de onda. Ex: $\mathrm{AUR}_{810}$.

DAE: dias após a emergência.

HAA: absorção da radiação solar pela área foliar sadia (Healthy Area Absorption).

HAD: duração da área foliar sadia (Healthy Leaf Area Duration).

HLAI: $\quad$ índice de área foliar sadia (Healthy Leaf Area Index).

HRI: $\quad$ absorção da área foliar sadia por unidade de tempo.

IR/R: indice vegetativo que relaciona refletância na faixa do infra vermelho (IR) e vermelho (R).

IR: $\quad$ refletância na região do infravermelho (Infra Red).

LAI: $\quad$ índice de área foliar (Leaf Area Index).

LDE: limiar de dano econômico.

$\mathrm{ND}$ : índice vegetativo que usa a fórmula $\mathrm{ND}=(\mathrm{IR}-\mathrm{R}) /(\mathrm{IR}+\mathrm{R})$ (Normalized Difference).

$\mathrm{ND}_{810,610}$ : diferença normalizada que usa os comprimentos de onda de $810 \mathrm{~nm}$ e $610 \mathrm{~nm}$.

$\mathrm{ND}_{810,660}$ : diferença normalizada que usa os comprimentos de onda de $810 \mathrm{~nm}$ e $660 \mathrm{~nm}$.

NIR: $\quad$ faixa do espectro do infravermelho próximo (Near Infra-Red).

PAR: $\quad$ radiação fotossinteticamente ativa (Photosynthetically Active Radiation).

R: $\quad$ refletância na região do vermelho (Red).

RI: radiação interceptada.

RUE: eficiência de uso da radiação, em $\mathrm{g} \mathrm{MJ}^{-1}$. 


\section{Curriculum vitae}

Leonardo Gianasi nasceu em 24 de dezembro de 1971 na cidade de Varginha, MG. Recebeu o título de Engenheiro Agrônomo em 30 de janeiro de 1994, na Escola Superior de Agricultura de Lavras, ESAL, Lavras, MG. Obteve o título de Mestre em Agronomia, área de concentração Fitossanidade em 30 de janeiro de 1996, na Universidade Federal de Lavras, UFLA, em Lavras, MG.

Autor e co-autor em mais de 40 trabalhos apresentados em congressos. Possui alguns artigos publicados na íntegra. Atuou na área de extensão rural estando vinculado à Cooperativa dos Cafeicultores da Zona de Varginha. Trabalhou conjuntamente com várias empresas na pesquisa e desenvolvimento de fungicidas. Atualmente é pesquisador da Empresa de Pesquisa Agropecuária de Minas Gerais, EPAMIG, estando lotado no Centro Tecnológico do Centro Oeste - Fazenda Experimental Santa Rita, sendo responsável por problemas fitopatológicos no Programa Olericultura. 


\title{
ANTRACNOSE DO FEIJOEIRO: QUANTIFICAÇÃO DE DANOS E EFEITO DO TRIFENIL ACETATO DE ESTANHO NO CRECIMENTO DO HOSPEDEIRO E NO PROGRESSO DA DOENCA
}

\author{
Autor: Leonardo Gianasi \\ Orientador: Prof. Dr. Armando Bergamin Filho
}

\section{RESUMO}

Foram conduzidos três experimentos com feijoeiro cultivar 'Carioca', para se investigarem a possibilidade de implementação de um sistema de manejo integrado da antracnose do feijoeiro. Na primeira etapa realizou-se a quantificação de danos nesse patossistema. A incorporação da desfolha do hospedeiro em funções de dano baseadas em severidade de doença, melhorou o ajuste da função. Entretanto, melhores resultados foram encontrados para as funções fundamentadas em variáveis derivadas de área foliar sadia. Propôs-se um limiar de dano econômico a partir dos resultados observados. Numa segunda etapa, procurou-se, por meio de técnicas de sensoriamento remoto, utilizando radiômetro de múltiplo espectro, relacionar doença e as variáveis de área foliar com medidas de refletância. Observou-se que desfolha e severidade de antracnose apresentaram baixas relações lineares com medidas de refletância. As melhores relações lineares com índice de área foliar (LAI), índice de área foliar sadia (HLAI), e absorção de área foliar sadia por unidade de tempo, HRI, foram obtidas com a refletância em 760 e $810 \mathrm{~nm}$, e para diferença normalizada $\left(\mathrm{ND}_{810,660}\right)$. Apresentou-se um modelo para estimar o índice de área foliar sadio, HLAI, em função da refletância em $810 \mathrm{~nm}$. Na última etapa do trabalho verificou-se qual o 
comportamento da severidade de doença, desfolha, área sob a curva de progresso da doença, área sob a curva de progresso de doença (AUDPC), índice de área foliar (LAI), índice de área foliar sadia (HLAI), absorção da área foliar por unidade de tempo (HRI), duração da área foliar sadia (HAD), absorção da área foliar sadia (HAA) e produção, após intervenção no patossistema feijão/antracnose (Colletotrichum lindemuthianum) com o fungicida trifenil acetato de estanho em dosagens de $0,2 \mathrm{~kg} / \mathrm{ha}$. Os resultados demonstraram reduções significativas na severidade de doença e desfolha do hospedeiro, após o início das pulverizações na parcela controle. Não se observaram diferenças entre os valores de LAI para os tratamentos. Entretanto, os valores de HLAI e HRI apresentaram diferença estatisticamente significativa. Maiores valores de HLAI e HRI resultaram HAD e HAA superiores. Semelhantemente, maiores absorções de radiação resultaram em maiores produtividades. As avaliações semanais dos valores de HLAI e HRI demonstraram que a severidade de doença e/ou a desfolha os influenciam negativamente. Entretanto, essas variáveis responderam positivamente ao tratamento com o fungicida, indicando o potencial do emprego de variáveis derivadas da área foliar em um sistema de manejo da antracnose do feijoeiro baseado num limiar de dano econômico. 


\title{
ANTHRACNOSE OF BEAN: CROP DAMAGE AND EFFECT OF FENTIN ACETATE IN HOST GROWTH AND DISEASE PROGRESS
}

\author{
Author: Leonardo Gianasi \\ Adviser: Prof. Dr. Armando Bergamin Filho
}

\section{SUMMARY}

Three field experiments were conducted with bean cultivar 'Carioca', to investigate the possibility of implementation of integrated management of anthracnose. Initially, crop damage was quantified. Defoliation, when incorporated in disease severity to calculate area under disease progress curve (AUDPC), resulted in a best damage function than without defoliation. However, the best relationships were found for damage functions established for healting leaf area variables. In this paper, a damage threshold was proposed. In the second phase, the relationships between disease, healting leaf area variables, yield and canopy reflectance, were investigated with a multispectral radiometer. No wavelength or vegetation index could be used for good estimate of defoliation or disease severity in the field. Good relationships between leaf area index (LAI), healthy leaf area index (HLAI) and healthy leaf area absorption on any given day (HRI) were showed with reflectance at 760 and $810 \mathrm{~nm}$ and normalized difference, using 810 and $660 \mathrm{~nm}$. The reflectance at $810 \mathrm{~nm}$ was proposed in a model to estimate HLAI. In the last phase, disease severity progress, defoliation, AUDPC, LAI, HLAI, HRI, healthy leaf area duration (HAD), total healthy leaf area absorption (HAA) and yield were investigated after sprays with fentin acetate $(0,2$ $\mathrm{kg} / \mathrm{ha}$ ) in the bean/anthracnose (Colletotrichum lindemuthianum) pathosystem. The results showed the lowest host defoliation and disease severity after sprays in the 
control plot began. No difference was found for LAI. However, HLAI and HRI showed significant differences among treatments. The bigger values of HLAI and HRI resulted in bigger HAD, HAA, radiation absorption and yield values. A weekly assessment of HLAI and HRI values showed a negative effect of defoliation and disease severity in these variables. However, a positive effect in these variables was showed with sprays of fentin acetate. These results indicated the potential of using leaf area variables in an anthracnose management system based in a damage threshold. 


\section{INTRODUÇÃO}

O cultivo do feijoeiro (Phaseolus vulgaris L.) apresenta-se incorporado à agricultura há cerca de 8000 anos. Registros arqueológicos indicam que sua domesticação tenha ocorrido na região dos Andes, na América do Sul, e concomitantemente na região da Guatemala, na América Central (Michaels, 1994).

O feijoeiro comum é, dentre as leguminosas, a espécie mais importante para consumo humano, principalmente nos países da América Latina e África, onde é a principal fonte de proteína devido ao seu teor protéico de cerca de $22 \%$ e ao custo, relativamente baixo, perante as proteínas de origem animal (Vieira, 1988). A América Latina é a zona de maior produção e consumo, estimando-se que seja responsável por $30 \%$ da produção mundial (Sanders \& Schwartz, 1980; Michaels, 1994).

Destaca-se, como maior produtor mundial da leguminosa, o Brasil. Anualmente são plantados cerca de 3,8 milhões de hectares com uma produção de 2,2 milhões de toneladas, o que representa uma produtividade de $578 \mathrm{~kg} / \mathrm{ha}$ (Paraná, 1995).

Dentre outros fatores, a baixa produtividade média obtida deve-se à incidência de doenças na cultura. Bianchini et al. (1989) citam a existência de mais de 200 doenças capazes de afetar a cultura, limitando sua produção e reduzindo a qualidade fisiológica, sanitária, nutricional e comercial do produto. Dentre as doenças fúngicas destaca-se a antracnose do feijoeiro causada pelo fungo Colletotrichum lindemuthianum (Sacc. \& Magn.) Br. \& Cav. (Shands et al., 1964; Kimati, 1966; Trutmann \& Graf, 1993). 
A quantificação de danos causados por um patógeno é o passo inicial para o desenvolvimento de qualquer programa de manejo de doenças. Não se podem reduzir os prejuízos causados por uma doença a níveis aceitáveis sem se conhecer o dano causado por ela (Campbell \& Madden, 1990). Não se pode esperar a aplicação de recursos escassos destinados à pesquisa agropecuária na determinação de métodos de controle de doenças cujos danos não estejam bem caracterizados (James, 1974). Por outro lado, é necessário estimar a magnitude dos danos causados, para avaliar o ganho obtido pelo uso de determinada medida de controle (Chiarappa, 1971; James, 1974). Essa estimativa também serve de base para decisões políticas e governamentais (Campbell \& Madden, 1990). Deste modo, no contexto fitopatológico, a determinação dos prejuízos causados por fitopatógenos representa a definição do problema e seria ilógico, e certamente ineficiente, buscar soluções para um problema que ainda não tenha sido definido (Bergamin Filho, 1995).

Além de estimar possibilidade de decréscimo em produção, a quantificação de dano subsidia com informações o manejo de doenças (Campbell \& Madden, 1990). Esses modelos de avaliação de danos podem ser incorporados num sistema de manejo de doenças, o qual pode ser utilizado para prever o desenvolvimento da doença e prevenir a redução da produção através da utilização de medidas de controle (James \& Teng, 1979). Um modelo que captura a essência do efeito da doença sobre a produção permitirá, por exemplo, a determinação do limiar de danos econômicos para controle (Teng, 1987).

Nunes \& Bergamin Filho (1996), a partir dos conceitos propostos por Waggoner \& Berger (1987), procuraram estabelecer a função dano para o patossistema antracnose-feijoeiro. A função dano estabelecida dessa maneira, sugere possibilidade do uso desta metodologia na determinação do limiar de dano econômico e conseqüentemente implementação do manejo de doenças, conforme propuseram Bergamin Filho \& Amorim (1996) para o patossistema feijão/ferrugem e Bergamin Filho et al. (1997) para o patossistema feijão/mancha angular. Entretanto, nesses trabalhos, a quantificação da desfolha não foi realizada. A não mensuração da desfolha, 
promovida por um patógeno, é um dos fatores que impede o estabelecimento da função de dano baseado em severidade de doença (Waggoner \& Beger, 1987), e conseqüentemente leva ao encontro de melhores funções de dano baseadas em área foliar sadia.

O emprego dessas medidas requer imenso volume de trabalho nas avaliações. Para se viabilizar o uso da duração da área foliar sadia, HAD e absorção da área foliar sadia, HAA, no cálculo de danos, técnicas de sensoriamento remoto têm demonstrado potencial para execução de estimativas rápidas e precisas do índice de área foliar, principalmente sob condições de campo (Asrar et al., 1984; Nilsson, 1995; Nutter Jr. \& Littrell, 1996, Canteri et al., 1998).

Essas proposições ainda necessitam de validação, pois não se sabe ainda, por exemplo, o comportamento do índice de área foliar sadia e da própria doença, após a intervenção nesses patossistemas de uma medida de controle químico.

Os objetivos deste trabalho foram:

- Estabelecer a função de danos, da antracnose do feijoeiro, na cultivar Carioca comum, correlacionando-se doença, índice de área foliar sadia e produção.

- Avaliar a eficiência da técnica de sensoriamento remoto, por meio do radiômetro de múltiplo espectro, na quantificação do índice de área foliar sadia e da severidade de doença.

- Avaliar o crescimento do hospedeiro, por meio do índice de área foliar sadia e do progresso de doença, após a intervenção do fungicida trifenil acetato de estanho, em diferentes épocas, no patossistema feijão/antracnose.

- Estimar um limiar de dano econômico para o patossistema feijão antracnose e verificar o comportamento do crescimento do hospedeiro e do progresso de doença, após atingir esse limiar. 


\section{REVISÃO DE LITERATURA}

\subsection{A Antracnose do feijoeiro}

\subsubsection{Etiologia e morfologia}

A descrição original do patógeno foi feita por Saccardo \& Magnus, em 1878, como Gloeosporium lindemuthianum em material coletado por Lindemuth, em Bonn, Alemanha. Posteriormente, Scribner, notando a presença de setas, transferiu-o para o gênero Colletotrichum. A nomenclatura hoje empregada para a fase imperfeita do agente causal da antracnose do feijoeiro é Colletotrichum lindemuthianum (Zaumeyer \& Thomas, 1957). O estádio sexual do patógeno corresponde a Glomerella lindemuthiana (Schwartz, 1994).

O patógeno na fase conidial é mais comumente observado no feijoeiro. Seus micélios são inicialmente de coloração hialina a cinza, escurecendo-se rapidamente, atingindo a cor quase negra à medida que envelhece. (Walker, 1952; Schwartz, 1994). Os conídios hialinos, unicelulares, oblongos, cilíndricos com as pontas redondas ou apresentando uma delas pontiaguda, medem de 2,5-5,5 micras $\mathrm{x}$ 9,5-22 micras. Normalmente apresentam uma área clara, semelhante a um vacúolo na parte central. Um conídio pode formar de 1 a 4 tubos germinativos, sendo mais comum dois, os quais formam apressórios para penetração no hospedeiro. Os conídios são produzidos em acérvulos, que são os corpos de frutificação do patógeno, onde se forma 
abundante esporulação do patógeno, formando uma massa de esporos de cor rósea (Sartorato, 1988; Schwartz, 1994).

As setas podem ser encontradas no hospedeiro, porém é mais comum em meios de cultura. Elas são produzidas entre os conidióforos ou às margens dos acérvulos; são pontiagudas, rígidas, septadas de cor castanha, com 30 a 100 micras de comprimento (Zaumeyer \& Thomas, 1957).

Os conidióforos são hialinos, eretos sem ramificações com 40 a 60 micras de comprimento (Zaumeyer \& Thomas, 1957).

A fase sexual é caracterizada pela formação de peritécio, mais ou menos arredondado, com o diâmetro variando de 120 a 210 micras. A parede do peritécio é inicialmente hialina, e, à medida que envelhece, torna-se enegrecida. No seu interior encontram-se cerca de 30 ascas, onde são formados de 1 a 8 ascósporos (Sartorato, 1988).

\subsubsection{Sintomatologia}

A antracnose pode afetar toda a parte aérea do feijoeiro (Schwartz, 1994). Cotilédones infectados exibem pequenas lesões de coloração marrom a preta. Água de chuva, orvalho ou irrigação normalmente lavam os esporos produzidos nos cotilédones indo infectar o hipocótilo, onde são formadas pequenas lesões de coloração amarelada, que crescem longitudinalmente, resultando em lesões deprimidas de coloração marrom escura, causando o apodrecimento do hipocótilo (Sartorato, 1988; Schwartz, 1994).

No pecíolo e no caule, as lesões são geralmente ovaladas, deprimidas e de coloração escura. Tais lesões enfraquecem os pecíolos e caules, podendo tornar as plantas incapazes de suportar o peso de sua copa (Zambolim \& Chaves, 1978; Sartorato, 1988). 
Nas folhas, as lesões ocorrem inicialmente na face abacial, ao longo das nervuras, como pequenas manchas de cor pardo-avermelhada, as quais, posteriormente, tornam-se de cor café-escura a negra. Tanto as nervuras principais como as secundárias podem apresentar-se infectadas. Quando a infecção é muito severa, formam-se lesões necrosadas nos tecidos adjacentes à nervura, podendo levar a completa necrose das folhas, que ainda permanecem aderidas às plantas (Zambolim \& Chaves, 1978; Sartorato, 1988, Schwartz, 1994).

Nas vagens, as lesões são arredondadas, deprimidas; de tamanho variável, apresentando o centro claro e delimitado por um anel negro, levemente protuberante, que geralmente se acha rodeado por um bordo de coloração caféavermelhada. As lesões podem coalescer e cobrir parcialmente as vagens. Sob temperatura e umidade adequadas, observa-se esporulação rosada no centro das lesões (Zambolim \& Chaves, 1978; Sartorato, 1988; Schwartz, 1994).

O patógeno pode invadir as vagens e afetar as sementes, ao atravessar o tegumento, produzindo lesões nos tecidos dos cotilédones. As lesões são cancros ligeiramente deprimidos e de tamanho variado. As sementes infectadas são geralmente descoloridas, podendo apresentar cancros cuja coloração varia de amarela a café-escura ou negra (Sartorato, 1988; Schwartz, 1994).

\subsubsection{Ocorrência e importância}

A antracnose é amplamente distribuída por todo o mundo, mas segundo Schwartz (1994), maiores danos ocorrem nas regiões temperadas e subtropicais que na região tropical.

Existem relatos da doença em todo o Continente Americano, bem como na Europa, África, Austrália e Ásia. Esta ampla distribuição torna a antracnose uma das mais importantes doenças do feijão no mundo. (Schwartz, 1994). 
No Brasil a antracnose é de bastante importância nos principais Estados produtores, tais como Rio Grande do Sul, Santa Catarina, Paraná, São Paulo, Minas Gerais, Bahia, Pernambuco, Espírito Santo, Alagoas, Sergipe e Paraiba (Sartorato, 1988).

Além da importância justificada pela vasta distribuição do parógeno, pode-se também encontrar citações de perdas de até $100 \%$, quando são semeadas sementes infectadas e ou ocorrem condições favoráveis (Sartorato, 1988).

Trutmann \& Graf (1993) compararam o impacto de diferentes doenças e pragas sob o sistema produtivo de feijão em Ruanda. Os autores verificaram que maiores incrementos em produtividade da cultura eram obtidos quando se fazia controle de doenças. Dentre as doenças, os autores observaram que, nas regiões estudadas naquele País, as situadas em médias e altas altitudes apresentaram maiores danos provocadas pela antracnose. Em média de todas as regiões os autores observaram que a antracnose é o segundo fator mais limitante da cultura e que o seu controle é responsável pela redução de $7 \%$ de danos na produção nacional.

Acredita-se que no Brasil tal fato também se verifica, principalmente pela visão mais empresarial, hoje dedicada à cultura, e agravada pelo sistema de plantio em terceira época, em que as temperaturas mais amenas e a alta umidade relativa, provocadas pelos sistemas de irrigação por aspersão ou pivô central, fornecem ótimas condições para o progresso da doença.

\subsubsection{Epidemiologia e ciclo da doença}

O fungo sobrevive entre as estações de cultivo como micélio dormente dentro do tegumento da semente nas células dos cotilédones, na forma de esporos ou em restos culturais. A transmissão do patógeno, a longas distâncias, é realizada pela semente. A curtas distâncias, a transmissão pode ser realizada pelos respingos de água de chuva ou irrigação, ao disseminar os esporos que se encontram embebidos numa 
substância gelatinosa solúvel em água. Deste modo a disseminação é mais rápida e eficiente. $O$ homem, ao caminhar entre as plantas úmidas, também colabora na distribuição do patógeno. Insetos, animais e máquinas agrícolas também podem ser considerados como agentes de disseminação (Zaumeyer \& Thomas, 1957; Costa, 1972; Zambolim \& Chaves, 1978; Sartorato, 1988).

Após o conídio ter atingido a superfície da planta, ele pode, sob condições favoráveis do ambiente, germinar dentro de 6 a 9 horas, formando de um a quatro tubos germinativos e apressórios, os quais se fixam à cutícula do hospedeiro por meio de uma substância gelatinosa. A hifa infectiva origina-se do apressório e penetra na cutícula e epiderme do hospedeiro, através de forças mecânicas, crescendo entre as paredes celulares e os protoplastos por dois a quatro dias sem causar danos aparentes às células do hospedeiro. Vários dias mais tarde, as paredes celulares são degradadas enzimaticamente, provavelmente devido à ação da alfa-galactosidase, e o protoplasto morre, produzindo lesões encharcadas, que escurecem devido ao alto conteúdo de tanino.

O crescimento do micélio, debaixo da epiderme, produz cavidades que transformam em acérvulos ao romperem a cutícula do hospedeiro. Cada acérvulo contém de 3 a 50 conidióforos. Os conídios são formados em meio a uma substância gelatinosa, solúvel em água e servem como fonte de inóculo secundário. (Zaumeyer \& Thomas, 1957; Sartorato, 1988; Schwartz, 1994).

A produção de conídios e infecção das plantas são favorecidas por temperaturas de $13-26{ }^{\circ} \mathrm{C}$, com ótimo de $17{ }^{\circ} \mathrm{C}$. Umidade relativa maior que $92 \%$ é necessária durante toda a fase de germinação do conídio e subseqüente esporulação (Schwartz, 1994). Rahe \& Kuc (1970) verificaram que temperaturas acima de $30^{\circ} \mathrm{C}$ e abaixo de $13{ }^{\circ} \mathrm{C}$ limitam tanto a infecção como o desenvolvimento do patógeno nas plantas. Zaumeyer \& Thomas (1957) verificaram como ótimas para esporulação do patógeno, em lesões produzidas nas vagens, as temperaturas de 14 a $18^{\circ} \mathrm{C}$. 
Schwartz (1994), cita que além das condições descritas acima, a presença de chuvas suaves em intervalos freqüentes, principalmente acompanhadas por ventos, são essenciais para a disseminação de conídios e desenvolvimento de severas epidemias.

Nunes \& Bergamin Filho (1996) comentam que de acordo com essas características necessárias ao progresso da doença, não se verificam epidemias de Colletotrichum lindemuthianum nas estações secas do ano. Atualmente, os plantios em terceira época, em sistemas irrigados e associados à presença de chuvas esporádicas, têm levado a severas epidemias do patógeno, com enormes danos.

\subsubsection{Controle}

Sartorato (1988) recomenda para controle da antracnose do feijoeiro o uso de: práticas culturais, controle genético e controle químico.

Dentre as práticas culturais o emprego de sementes livres do patógeno é a que apresenta melhor resultado. (Zaumeyer \& Thomas, 1957; Zambolim \& Chaves, 1978; CIAT, 1981). Sartorato (1988) cita que o uso de sementes livres do patógeno e o aperfeiçoamento da técnica de cultivo foram responsáveis por um incremento de $300 \%$ na produtividade do feijão em pequenas propriedades na Guatemala.

Outra prática cultural importante é rotação de cultura por pelo menos dois a três anos, pois o patógeno pode sobreviver no solo ou nos restos culturais.

$A$ incorporação da resistência à antracnose em materiais agronomicamente bem adaptados é uma fase muito importante em qualquer programa de melhoramento. Muitas fontes de resistência já foram determinadas e são portanto passíveis de serem introduzidas aos programas de melhoramento (Hubbeling, 1957; Bannerot, 1965; Goth \& Zaumeyer, 1965; Steadman, 1974; Fonilloux, 1976; Hallard \& Trebuchet, 1976; CIAT, 1981; Park et al., 1982; Schwartz et al., 1982; Genchev \& Mitranov, 1983). Contudo, o desenvolvimento de cultivares resistentes, através da 
hibridação, é dificultado sobremaneira pela variabilidade que o patógeno apresenta, possuindo diversas raças fisiológicas, sendo bastante difícil a incorporação em um único genótipo resistência para os principais patótipos do agente causal. (Alzate-Marin et al., 1995; Rava et al., 1998).

O controle químico é uma das principais práticas de controle da antracnose. Pode-se realizar tratamento de sementes, sendo recomendados benomil, tiofanato metilico, tiofanato metílico + thiram, benomil + thiram. (Ellis et al., 1976; Maude, 1977; Bianchini et al. 1978) fludioxonil, difenoconazole, thiram (Menten et al., 1996). Entretanto, devido ao aparecimento de biótipo resistente no benomil, deve-se tomar cuidado no tratamento de sementes com esse fungicida (Tu, 1980).

Vários estudos têm demonstrado a eficiência de fungicidas sob condições de campo. As recomendações atuais preconizam início dos tratamentos quando aparecem os primeiros sintomas (Sartorato, 1988). São eficientes: maneb (Issa \& Arruda, 1964); zineb (Zambolim \& Chaves, 1978); benomil (Giroto, 1974; Navarro $\&$ Puerta, 1983) carbendazin (Giroto, 1974; Bianchini et al., 1978); mancozeb (Issa \& Arruda, 1964); chlorothalonil (Bianchini et al., 1978; Navarro \& Puerta, 1983); trifenil acetato de estanho (Thomson, 1973; Mohan et al., 1981); hexaconazole + chlorothalonil (De Vincenzo et al., 1995); tebuconzole (Galli et al., 1995); azoxystrobin (Adoryan et al., 1996).

\subsection{Avaliação de danos}

\subsubsection{Definições}

Inicialmente, as doenças de plantas começaram a ser estudadas em função do dano que causavam; entretanto, ainda hoje, poucas são as estimativas confiáveis de danos causados por patógenos. A ausência dessas relações foi o fator que mais retardou o progresso do manejo de doenças de plantas (James, 1974). 
Para o desenvolvimento de métodos de controle econômicos e racionais, dentro do contexto de manejo de doenças, não basta apenas afirmar que uma doença leva a perdas, mas a magnitude do dano deve ser avaliada, para poder ser correlacionada com o ganho obtido. Somente após a relação doença-dano ser estabelecida, é possível determinar as perdas econômicas devido às diferentes intensidades de doença (James, 1974; James \& Teng, 1979).

Objetivando-se um consenso de idéias, faz-se necessária uma definição precisa dos termos utilizados pelos fitopatologistas (Godoy, 1995). Desta forma, Zadoks (1985) propõe que organismo nocivo é qualquer agente biológico que danifique uma plantação. Produção é o produto mensurável de valor econômico de uma plantação. Qualquer sintoma causado por um organismo nocivo é injúria e a redução na quantidade e/ou qualidade da produção é chamada de dano. A redução em retorno financeiro, por unidade de área, devido à ação de organismos nocivos é chamada de perda.

Pela definição clássica de nível de dano econômico, esta é a menor população que poderá causar dano, e posteriormente foi redefinida como o nível de organismo nocivo cujos benefícios advindos do controle se igualam aos custos gastos nessa operação. Esta terminologia foi criada pelos entomologistas e por ser confusa aos fitopatologistas, sugere-se o termo limiar de dano econômico (Bergamin Filho, 1995).

De acordo com a FAO (1968), o controle integrado de doenças pode ser definido como um sistema de manejo de doenças que utiliza todas as técnicas disponíveis para manter as doenças abaixo do limiar de dano. Dentre esses métodos utilizados, alguns são definidos antes da instalação da cultura, como, por exemplo, a escolha da cultivar. No entanto, outros precisam ser decididos durante o crescimento da cultura, como a escolha do fungicida e a época de sua aplicação. Neste caso, a decisão necessita de informações, como a previsão do crescimento da doença durante o ciclo, as perdas que poderão advir se o controle não foi efetuado, e a relação custo-benefício de cada tratamento. 
Esse pensamento prevalece atualmente, substituindo o conceito de gerações anteriores sobre erradicação de pragas e doenças. Manejo de pragas e doenças é inerente a uma compreensão mais complexa de ecossistemas, dinâmica de população, genética e produção econômica de culturas, procurando um programa de medidas que irão manter os organismos nocivos abaixo do limiar de dano econômico. No entanto Zadoks \& Schein (1979) citam que um longo e tedioso trabalho, além de transpor uma série de dificuldades, deve ser executado para a obtenção do manejo de doenças.

\subsubsection{Quantificação de doenças}

Ao se estimarem os danos que uma doença causa à produção, tem-se como meta final o estabelecimento da função de dano. Para se obterem os dados que compõem essa função é necessário avaliar a injúria causada pela doença, que no contexto fitopatológico pode ser traduzida por incidência ou severidade da doença, e o dano decorrente dessa injúria, como reduções quantitativas da produção (Iamauti, 1995).

Incidência pode ser definida como a porcentagem de plantas, ou de seus órgãos doentes em uma população. Este método de quantificação de doenças pode ser considerado de alta precisão e simplicidade, sendo os dados facilmente reproduzíveis, porém com aplicabilidade limitada às doenças sistêmicas ou àquelas nas quais uma única lesão inviabiliza a comercialização do produto. A severidade é definida como a área de tecido foliar afetado pela doença, expressa com relação à proporção total de área. Sua aplicabilidade é maior no caso de doenças foliares, já que se encontra muito ligada à produtividade e, conseqüentemente, aos danos causados pelas doenças (James, 1974; Kranz, 1988).

Tem-se, ainda, um termo, mais geral, usado para a quantificação de doenças, a intensidade, que se pode referir tanto à incidência como à severidade (Chiarappa, 1971). 
$\mathrm{Na}$ determinação de severidade tem-se utilizado de chaves descritivas, escalas diagramáticas, análise de imagem e sensoriamento remoto (James, 1974; James \& Teng, 1979; Gaunt, 1987; Kranz, 1988). Dentre esses métodos, o uso de escalas diagramáticas é o de maior rapidez e menor custo, o que o torna mais atraente em situações onde grande número de amostras deve ser analisado (Amorim \& Bergamin Filho, 1991), constituindo-se, atualmente, na principal ferramenta de avaliação da severidade de doença em muitas plantas (Bergamin Filho et al., 1995).

\subsubsection{Metodologia para quantificação de danos}

Vários métodos têm sido empregados para a quantificação de danos em ensaios de campo. Dentre eles destacam-se o método da parcela experimental e o da planta individual.

O método da parcela experimental baseia-se no chamado tratamento pareado, que consiste de parcelas gêmeas, sadias e doentes (Chiarappa, 1971). Cada par origina um conjunto de dados com diferentes intensidades de doença e conseqüentes danos (Shane \& Teng, 1987). Mais recentemente, tem-se dado preferência a dois ou, usualmente, a mais níveis de intensidade de doença no mesmo experimento (Campbell \& Madden, 1990). Múltiplos níveis de injúria podem ser obtidos pela inoculação artificial com diferentes concentrações de inóculo, em diferentes épocas e frequências, pelo uso de fungicidas, de linhas isogênicas, ou manipulação do ambiente (Sah \& Mackenzie, 1987; Madden, 1983).

Bergamin Filho \& Amorim (1996) recomendam um mínimo de três repetições para qualquer das abordagens.

O cálculo do dano implica na determinação da produção das parcelas sadias e nas parcelas com diferentes niveis de doença. O dano, portanto, é expresso pela diferença de produção entre as parcelas sadias e doentes (Bergamin Filho \& Amorim, 1996). 
No método da planta individual, indivíduos sadios e doentes encontrados no campo comercial ou experimental, substituem as parcelas. A doença é avaliada em grande número de plantas (50 a 2000) com uma ampla faixa de niveis de severidade. As plantas são marcadas, avaliadas pela intensidade de doença e colhidas quando atingirem a maturidade para avaliar-se a produção (Campbell \& Madden, 1990). As vantagens deste método são a utilização de epidemias naturais, variação completa no nível de intensidade de doença, que pode ser conseguida durante uma única estação de cultivo e economia de tempo e espaço. A principal desvantagem do método decorre do fato de os modelos resultantes explicarem somente uma pequena quantidade de variação da produção devido à doença, pois existe uma diferença de produção inerente entre plantas (James \& Teng, 1979).

\subsubsection{Modelos para estimativa de danos}

Para se sintetizar a grande quantidade de dados que são gerados em experimentos que estudam a relação doença-dano, utiliza-se de modelos matemáticos (Campbell \& Madden, 1990).

Teng (1985) sugeriu que esses modelos fossem classificados como empíricos, explanatórios e conceituais. O modelo empírico é o mais amplamente aplicado para avaliação de danos e desenvolvido a partir de dados experimentais. Simulação de danos requerem modelos explanatórios, e os conceituais utilizam o conhecimento existente de fisiologia vegetal e os efeitos da doença na produção para formular prováveis respostas.

Teng (1985) considera como modelos empíricos os de ponto crítico, múltiplos pontos, integral, superficie de resposta e sinóptico.

Os modelos do ponto crítico implicam na existência de um ponto crítico, no qual a cultura é particularmente sensível à doença, e a intensidade de doença presente está altamente correlacionada com o dano futuro; desta forma, uma só variável 
independente reflete, com maior ou menor precisão, toda epidemia. Romig \& Calpouzos (1970) obtiveram sucesso no uso deste modelo para o patossistema trigo Puccinia graminis f. sp. tritici, no qual a severidade de doença no estádio 11.1 da escala de Feeks correlaciona-se com a percentagem de dano. A mesma abordagem foi utilizada por Pataky et al. (1983) para Cilindrocladium crotalariae em amendoim, e por Ayers et al. (1976) para Helminthosporium maydis raça T em milho.

Nos modelos de múltiplos pontos, a estimativa de danos é baseada numa seqüência de avaliação durante a estação de cultivo. Esse tipo de modelo irá ser mais aplicado do que os modelos de ponto crítico em situações onde o acúmulo de produção ocorrer durante um período relativamente longo e/ou a taxa de progresso da doença ser altamente variável (James, 1974). Esse modelo foi aplicado por James et al. (1972) no patossistema batata Phytophthora infestans, no qual o dano é relacionado com a intensidade de doença observada durante nove períodos semanais através de uma equação de regressão múltipla:

$$
Y=B_{1} X_{1}+B_{2} X_{2}+\ldots .+B_{n} X_{n} \text {, onde } \mathrm{Y} \text { é a percentagem de dano na }
$$
produção e $\mathrm{X}$ é a intensidade de doença no tempo $\mathrm{n}$.

Este modelo parece mais adequado a essa cultura, uma vez que não existe, como nos cereais, uma mudança morfológica óbvia que possa ser usada como período crítico. Além disso, a tuberização é um processo longo e, portanto, mudanças no nivel de doença em qualquer fase do ciclo podem afetar a produção.

Modelos integrais relacionam danos com alguma variável que represente a totalidade de uma epidemia (Teng, 1985). A variável mais utilizada é área sob a curva de progresso da doença (AUDPC - area under the disease progress curve) (Vanderplank, 1963). A vantagem desse modelo, em relação ao do ponto crítico, é a de distinguir duas epidemias com diferentes áreas sobre a curva de progresso da doença, mas com mesma percentagem de severidade no período crítico. Por outro lado, ele não tem a vantagem do modelo de múltiplos pontos de aplicar diferentes pesos à doença nas diferentes épocas de avaliação (James, 1974), nem é apropriado para uso em programa de manejo de doenças (Bergamin Filho, 1995). 
Schneider et al. (1976) relacionaram a percentagem de dano com AUDPC no patossistema Vigna unguculata - Cercospora spp. Outros bons resultados foram obtidos por Lim (1980) e Broscious et al. (1987).

Os modelos de superfície de resposta estimam dano a partir de duas entradas, seguindo a equação geral: \% Dano $=f_{(X, T)}$, em que $X$ é usualmente a severidade da doença e $T$ o estádio de desenvolvimento do hospedeiro.

Modelos sinópticos, diferentemente dos demais, abordam múltiplos fatores limitantes da produção, bióticas ou abióticas. No sistema de produção atual, esse modelo é mais apropriado por ser comum a ocorrência concomitante de diferentes organismos nocivos.

\subsubsection{Avaliação de danos por meio da área foliar fotossintetizante}

Os modelos discutidos anteriormente apresentam um problema em comum. Eles relacionam dano com severidade de doença, esquecendo-se do hospedeiro. Apesar da intensa pesquisa nos últimos anos existem poucos casos em que dano ou produção podem ser avaliados com a precisão e repetibilidade necessárias para permitir estimativas em larga escala (Madden, 1983). Sem considerar as respostas fisiológicas das plantas aos patógenos não será possivel uma completa compreensão do processo de dano e, portanto, o estabelecimento de estratégias adequadas de manejo de doenças (Boote et al., 1983).

O parâmetro área foliar total é o mais comumente utilizado por agrônomos e fisiologistas, para descreverem e explicarem diferenças em potencial de crescimento de plantas submetidas a diferentes tratamentos, e é freqüentemente correlacionado, o índice de área foliar com produção (Gaunt, 1981). Bons exemplos dessas correlações foram obtidos por Last (1962), o qual no patossistema cevada Erysiphe graminis já sugeria a correlação de área foliar sadia com produção. Jenkyn (1976), estudando o mesmo patossistema, verificou que a duração da área foliar estava 
bastante relacionada com produção, e que maiores durações da área foliar eram obtidas com o controle químico do patógeno.

Deste modo, Lim \& Gaunt (1981) chamaram a atenção para a importância da avaliação da área foliar em trabalho de quantificação de danos, uma vez que a simples avaliação da severidade ignora o efeito do tamanho da planta e, portanto, do efeito total da doença sobre o crescimento da planta e a produção. Lim \& Gaunt (1986), estudando o patossistema cevada Erysiphe graminis f. sp. hordei e Puccinia hordei, observaram que área foliar verde (GLA - green leaf area) estava mais correlacionada com produção que com severidade de doença. Deste modo os autores concluíram que GLA é um parâmetro melhor do que severidade para avaliação de danos. Resultados semelhantes foram obtidos por Carver \& Griffiths (1982), Rotem et al (1983a) e Rotem et al. (1983b).

Os resultados desapontadores obtidos por fitopatologistas ao correlacionarem severidade de doenças e dano devem-se ao fato de que a lógica dessa relação é incerta, uma vez que a severidade da doença tem efeito diferente, caso ocorra precoce ou tardiamente no ciclo da cultura e porque a desfolha não é considerada nas avaliações de severidade (Waggoner \& Berger 1987).

Deste modo, Waggoner \& Berger (1987) sugerem relacionar a produção com a variável duração da área foliar sadia (HAD - healthy area duration), que é a integral do índice de área foliar sadia da cultura durante a estação de crescimento, como principal indicadora de produção. Ele pode ser calculada pela fórmula:

$$
\mathrm{HAD}=\sum_{i=1}^{n-1}\left\{\left[L A I_{i}\left(1-X_{i}\right)+L A I_{i+1}\left(1-X_{i+1}\right)\right] / 2\right\}\left(t_{i+1}-t_{i}\right)
$$

Em que $X$ representa o tecido doente, e, desta forma, $(1-X)$ representa o tecido sadio, $\mathrm{LAI}_{\mathrm{i}}$ é o índice de área foliar (LAI - leaf area índice) no tempo $t_{i}$.

Esses autores propuseram ainda que a produção seria melhor correlacionada a uma variável que levasse em consideração a quantidade de luz realmente absorvida pela folhagem, a absorção de luz da área foliar sadia (HAA - 
healthy area absoption), que de forma análoga é a integral da quantidade de insolação absorvida pela área foliar sadia, considerando-se a lei de Beer para expressar a transmissão de isolação $I\left(\mathrm{MJ} \mathrm{m}^{-2}\right)$ através da folhagem, onde a fração absorvida RI é dado por:

$$
\mathrm{RI}=[1-\exp (-k \mathrm{LAI})]
$$

sendo $k$ o coeficiente de extinção, valor próximo a um para plantas com folhas horizontais e ao redor de 0,3 para plantas eretas. Miglioranza (1992) determinou experimentalmente que o valor médio de $k$ para o feijoeiro é 0,7 . Desta forma, a variável HAA pode ser calculada por:

$$
\mathrm{HAA}=\sum_{i=1}^{n-1} I_{i}\left(\left\{\left(1-X_{i}\right)\left[1-\exp \left(-k L A I_{i}\right)\right]+\left(1-X_{i+1}\right)\left[1-\exp \left(-k L A I_{i+1}\right)\right]\right\} / 2\right)\left(t_{i+1}-t_{i}\right)
$$

Baseando-se nestes conceitos, Bergamin Filho et al. (1995) sugerem que a excessiva preocupação dos fitopatologistas com o patógeno, levou-os a esqueceremse do principal, que é o hospedeiro e suas folhas. Do mesmo modo Lopes et al. (1994) atribuem os resultados desapontadores obtidos por fitopatologistas na quantificação de danos ao seu "patógeno-centrismo".

Embora relativamente recente, a abordagem proposta por Waggoner \& Berger (1987) levou à publicação de diversos artigos científicos, que relacionaram duração da área foliar sadia (HAD) ou absorção de área foliar sadia (HAA) e produção.

Ferrandino \& Elmer (1992), estudando os danos causados por Septoria lycopersici em tomateiro, observaram que o maior efeito da doença sobre a produção foi na redução do HAD, e que este seria melhor que AUDPC para estimar a produção.

Estudando o patossistema Vicia faba - Ascochyta ferbae Madeira et al. (1988) avaliaram os parâmetros HAD e HAA e encontraram relação linear entre os valores de HAA e produção de matéria seca, com alto coeficiente de correlação.

$\mathrm{Na}$ cultura do feijoeiro, a quantificação de danos de acordo com as propostas de Waggoner \& Berger (1987) foi realizada para os patógenos Colletotrichum lindemuthianum (Nunes \& Bergamin Filho, 1996); Uromyces appendiculatus (Iamauti, 1995); Phaeoisoriopsis griseola (Carneiro, 1995; Godoy, 
1995). Todos os autores encontraram relação linear entre HAD e produção. Para o parâmetro HAA, embora relações lineares com produção também tenham sido encontradas, observou-se também uma tendência exponencial nos dados obtidos. Entretanto, tais autores não quantificaram a desfolha do hospedeiro, o que pode explicar a não correlação de severidade de doença com produção.

A relação HAA e produção, usualmente é linear, ao contrário da relação produção e $\mathrm{HAD}$, que não é linear. Esta linearidade encontrada para o HAD pode ser explicada pelo hábito de crescimento indeterminado da cultivar estudada; quanto mais cresce a planta mais vagens são formadas (Bergamin Filho \& Amorim, 1996). A não linearidade entre HAA e produção também pode ser encontrada por Hughes et al. (1981) em feijão guandu.

As perspectivas vislumbradas por Waggoner \& Berger (1987) levaram Madden (1983) a manifestar seu entusiasmo, depois de lamentar as dificuldades de correlacionar injúria com danos. No entanto, o mesmo autor e também Campbell \& Madden (1990) reconhecem que determinar HAD e HAA é muito mais trabalhoso que avaliar a intensidade das doenças, que é uma medida relativa e pode ser realizada com o auxílio de escalas diagramáticas, enquanto aquelas são medidas absolutas, que exigem a determinação real da área foliar. Para superar as dificuldades na determinação de HAD e HAA, o desenvolvimento de técnicas de sensoriamento remoto trazem boas perspectivas na viabilização no uso desse conceito (Lopes et al., 1994).

\subsection{Manejo integrado de doenças}

Durante aproximadamente quatro décadas, a partir de 1930, o controle de pragas e, em menor grau, de doenças, teve como objetivo claro: erradicar os agentes nocivos. Erradicação, naquela época, tinha um sentido mais próximo de eliminar complemente o agente nocivo do que, como é corrente hoje, apenas reduzir sua população inicial. Essa visão absoluta de encarar o problema teve origem na 
entomologia aplicada, em decorrência do desenvolvimento de novos inseticidas, como o DDT e o BHC, produtos tão baratos e de tão largo espectro que qualquer consideração de ordem econômica era irrelevante. $O$ controle de pragas nesses anos baseou-se, portanto, num único método: a aplicação continuada de produtos químicos. Com o passar do tempo, porém, essa prática provocou sérias perturbações no ecossistema e no agroecossistema, como por exemplo a seleção de indivíduos resistentes, o ressurgimento de pragas e surtos epidêmicos de pragas de importância secundária (Bergamin Filho \& Amorim, 1996).

Paralelamente surgiram na área de entomologia florestal, pela própria característica do sistema, no qual o controle químico não é econômico, as idéias de controle biológico e o conceito da manutenção dos insetos em níveis economicamente toleráveis, por meio do manejo do ecossistema.

Deste modo surgiram os primeiros conceitos de controle integrado, como: "o controle aplicado de pragas que combina e integra os controles químico e biológico" (Stern et al., 1959).

Falhas espetaculares em alguns programas tradicionais de erradicação química, considerações de ordem econômica e o surgimento de uma consciência ecológica ambiental levaram a fácil adoção das ideologias pregadas pelo manejo integrado de doenças e pragas.

Chiarappa (1974) propôs o termo manejo integrado de doenças. Manejo implica na utilização de todas as técnicas disponíveis dentro de um programa unificado, de modo a manter a população de organismos nocivos abaixo do limiar de dano econômico e a minimizar os efeitos colaterais deletérios do meio ambiente (NAS, 1969).

Sistemas de manejo integrado procuram fazer com que a produção atual de uma área se aproxime ao máximo da produção econômica, com a menor agressão possível ao homem e ao meio ambiente (Bergamin Filho \& Amorim, 1996). A produção econômica pode ser definida como o nivel de produção em que há maior lucro para o agricultor (Zadoks \& Schein, 1979). Sua definição não é fácil, pois os 
preços dos produtos variam conforme as leis de mercado e os subsídios governamentais, entre outros fatores. A aplicação prática dos sistemas de manejo integrado depende de estudos sobre o limiar de dano econômico e de considerações sobre custo/benefício, para cada patossistema. Limiar de dano econômico (LDE) pode ser definido como a intensidade de doença na qual o benefício do controle se iguala ao custo do controle (Zadoks, 1985). O LDE não é estático e imutável (Canteri et al., 1998). Exemplos para seu cálculo podem ser encontrados em Bergamin Filho \& Amorim (1996). A dificuldade para calculá-lo é um dos motivos da pequena quantidade de trabalhos com aplicações práticas sobre o assunto, apesar do LDE ser a pedra fundamental do manejo integrado de doença (Zadoks, 1985). Dentre as razões para isto, percebe-se, segundo Bergamin Filho (1995), a incerteza avaliada na relação doença-dano já discutida anteriormente.

\subsubsection{HAD, HAA e o limiar de dano econômico}

Baseados na incerteza da relação doença-dano, Bergamin Filho \& Amorim (1996) propuseram uma nova abordagem para o LDE. A idéia seria criar um sistema transportável capaz de produzir recomendações precisas e exatas a nivel de propriedade, especialmente adaptado às condições tropicais e subtropicais. Este é o principal objetivo a ser alcançado com o desenvolvimento e implementação dessa nova abordagem para o limiar de dano econômico. Dois de seus componentes relacionam-se diretamente com esse objetivo, o primeiro já bastante discutido; é a variável explanatória absorção da área foliar sadia (HAA), o segundo é a utilização da parcela controle, PC, livre de doença, indispensável para cada situação de produção, SP, e responsável pela transportabilidade do sistema (Lopes et al., 1994).

Ensaios apropriados de campo permitirão o estabelecimento da relação entre a diminuição entre HAA e a respectiva diminuição da produção, ou seja, o estabelecimento da função de dano. A partir dessa relação, e contando com 
informações sobre a eficiência das possíveis medidas de controle, incluindo a recuperação de HAA, e sobre os custos e benefícios envolvidos, chega-se a determinação do novo limiar de dano econômico ( $\mathrm{LDE}_{\mathrm{HAA}}$ ) agora não mais expresso em insetos por planta ou severidade de doença, ambos de relação incerta com produção, e sim em unidades de HAA (MJ m ${ }^{-2}$ ). Com essas informações disponiveis, medidas de controle só serão recomendadas pelo sistema de manejo integrado de pragas e doenças quando a variação de HAA for superior ao $L D E_{\mathrm{HAA}} \cdot \Delta_{\mathrm{HAA}}=\mathrm{HAAPC}-$ HAAsp.

Deste modo, a recomendação de qual produto aplicar ou que medida de controle empregar dependerá da dimensão do HAAsp.

Há outras variáveis explanatórias de mais fácil quantificação que HAA, que podem ser usadas em sistema de manejo integrado de doenças, como por exemplo $\mathrm{HAD}$, e o mesmo raciocínio acima pode ser adotado (Bergamin Filho \& Amorim, 1996).

Entretanto, para tomada de decisão, variáveis integrais como $\mathrm{HAD}$, ou HAA não são apropriadas. (Madden \& Nutter Jr., 1995). Estes autores sugerem ser melhor o desenvolvimento de modelos de ponto crítico usando o índice de área foliar sadio (HLAI - Healthy leaf area indice) e radiação interceptada pela porção sadia da planta por unidade de tempo (HRI - Healthy radiation intercepted) para estimar-se a produção em diferentes épocas durante o ciclo da cultura.

Os resultados de Bergamin Filho et al. (1997) demonstraram que os coeficientes angulares da regressão entre a produção do feijoeiro e HLAI e HRI, apresentavam muito variáveis no estádio de crescimento $V_{3}$ de Michaels (1994) e tendem a estabilizar-se entre os estádios de crescimento $R_{5}-R_{8}$. Esta estabilização permite sua utilização como uma variável chave no sistema de manejo de doenças. Eles verificaram que tal estabilização dá-se ao redor de $26,8 \mathrm{~g} \mathrm{MJ}^{1}$, o que significa que para cada unidade de HRI ocorre um incremento de $268 \mathrm{~kg} \mathrm{ha}^{-1}$, se considerarmos 200.000 planta ha ${ }^{-1}$. Tem-se que o custo de controle de doenças no feijoeiro seja da ordem de 
US $\$ 40 \mathrm{ha}^{-1}$ e que este valor equivale a aproximadamente $96 \mathrm{~kg}$ de feijão. Este custo de $96 \mathrm{~kg} \mathrm{ha}^{-1}$ equivale a aproximadamente $1 / 3$ do benefício advindo do controle que é 268 $\mathrm{kg} \mathrm{ha}^{-1}(96 / 268=0,36)$. Deste modo, tem-se que quando a diferença entre o HRI no sistema produtivo e a parcela controle for de $1 / 3$ da unidade, já se recomenda 0 controle, ou seja, tem-se grosseiramente o nível de dano em 1/3 de HRI. Lembrando-se que a variável quantificada a nível de campo e utilizada para cálculo do HRI é HLAI, são necessários acurácias da ordem de $1 / 20$ unidade HLAI para culturas de feijão com HLAI de $0,2,1 / 10$ para $1,2,1 / 5$ para $2,2,1 / 3$ para $2,9,1 / 2,5$ para $3,2,1 / 2$ para 3,5 e $1 / 1$ para 4,5 (valores calculados para radiação média de $\mathrm{I}=12,0 \mathrm{MJ} \mathrm{m}^{-2}$ e $\mathrm{K}=0,7$ ).

Resultados semelhantes foram observados por Bergamin Filho \& Amorim (1996), entretanto, os autores utilizaram para cálculo do limiar de dano, HLAI e obtiveram como resultado que o limiar de dano estaria ao redor de 1/8 de HLAI.

Embora praticamente seja menos morosa a determinação do HLAI a nivel de extensionista e/ou produtor, quando comparada ao HRI, HLAI tem a desvantagem de ser influenciada pelo sistema de produção (Bergamin Filho et al., 1997).

Níveis de dano mais refinados somente poderão ser estabelecidos após o reconhecimento de qual é o efeito de medidas de controle sobre HLAI e HRI, o que atualmente na literatura é extremamente deficiente (Bergamin Filho \& Amorim, 1996).

Alguns trabalhos têm demonstrado que os valores de HRI e HLAI tornam-se maiores em sistemas onde são utilizados defensivos comparados ao sistema sem uso (Lim \& Gaunt, 1981; Rawlinson et al., 1984; Madeira et al., 1988; Aquino et al., 1992; Bourgeois \& Boote, 1992).

Finalmente, a implantação do manejo de doenças baseada em HRI ou HLAI esbarra na dificuldade de obtenção dos dados de área foliar e severidade de doença. Segundo Bergamin Filho et al. (1997), essas atividades demandam uma quantidade tremenda de trabalho de campo, o que dificulta sua implementação. Entretanto, o uso de técnicas de sensoriamento remoto tem-se mostrado promissor na estimativa de HLAI. 


\subsection{Sensoriamento remoto}

Jackson (1986) atribui ao sensoriamento remoto, o conjunto de técnicas capazes de obter informações de um objeto sem que haja contato físico com este objeto. Estas medidas são não destrutivas e não invasisvas e um objeto específico pode ser analisado muitas vezes sem danificar a amostra (Nilsson, 1995).

A aplicação dessas técnicas na fitopatometria baseia-se nas propriedades radiantes das plantas, refletância de certos comprimentos de onda, medidos por sensores especiais. A radiação refletida por uma folhagem é função de características da própria espécie vegetal e das condições em que se encontram as plantas. Pragas e doenças são responsáveis, freqüentemente, por muitos dos fatores que afetam a refletância das folhagens. Em geral, tecidos infectados apresentam menor refletância das folhagens na região do infravermelho (comprimento de ondas $>700 \mathrm{~nm}$ ) quando comparados com tecidos sadios (Bergamin Filho \& Amorim, 1996). A região do espectro de maior interesse à fitopatologia é a região do espectro refletivo $(380 \mathrm{~nm}$ a $3000 \mathrm{~nm}$ ), chamada dessa forma em razão da energia detectada nessa região ser basicamente originada da reflexão da energia solar por objetos na superficie terrestre. Pode ser dividido em três sub-regiões (Vettorazzi, 1992):

a) visível ( 380 a $720 \mathrm{~nm}$ ): corresponde à região em que o olho humano é capaz de responder à radiação eletromagnética. Também é conhecida como região das cores primárias;

b) infravermelho próximo (NIR) (720 a $1300 \mathrm{~nm})$;

c) infravermelho médio (1300 a $3000 \mathrm{~nm})$.

As técnicas de sensoriamento remoto disponíveis incluem fotografia aérea, onde podem ser utilizados diferentes combinações de filmes, filtros e câmaras, e os radiômetros de múltiplo espectro (Bergamin Filho \& Amorim, 1996).

A utilização de radiômetros é relativamente recente. Os primeiros relatos ocorreram na década passada (Pederson \& Gudmestad, 1977; Nilsson, 1980; Pederson 
\& Feichtner, 1980). Ultimamente, o assunto vem despertando o interesse dos pesquisadores, especialmente depois dos trabalhos de Nutter Jr. \& Cunfer (1988) e Nutter Jr. (1989). Uma boa revisão sobre o uso de radiômetros em fitopatometria, bem como os fatores que interferem na qualidade das leituras obtidas, podem ser encontrados em Canteri (1998).

Nutter Jr. (1989) verificou que a percentagem de refletância da copa do amendoim no comprimento de onda de $800 \mathrm{~nm}$, forneceu uma rápida e objetiva quantificação da intensidade de doença. Ele sugeriu que essa medida pode ser representativa da quantidade de HLAI. Entretanto, o índice de área foliar não foi determinado em seu estudo. Em outros estudos, Harlan et al. (1978) e Sharp et al. (1985) demonstraram o uso de radiômetro de múltiplo espectro na determinação da severidade de doenças e na estimativa da desfolha. Conseqüentemente verifica-se a possibilidade de seu uso na estimativa de HLAI.

Aquino et al. (1992) verificaram que para patossistema amendoim cultivar 'Florunner'/Cercosporidium personatum a refletância da copa a $800 \mathrm{~nm}$ diminuiu com o aumento da severidade de doença e desfolha durante a estação de cultivo. A percentagem de refletância a $800 \mathrm{~nm}$ foi correlacionada com HLAI. Os coeficientes de determinação $\left(\mathrm{R}^{2}\right)$ obtidos variaram de 77 a $95 \%$, indicando que a refletância de copa pode dar uma precisa estimativa de HLAI.

Nutter Jr. \& Littrell (1996) verificaram que no patossistema amendoim/Cercosporidium personatum, a refletância obtida pelo radiômetro de múltiplo espectro correlacionou-se melhor com a produção de vagens do que a análise visual de desfolha. Verificaram, também, uma forte e negativa relação entre refletância da copa e percentagem de desfolha. Os autores observaram, ainda, que a área sobre a curva de percentagem de refletância estava altamente correlacionada com a produção. Esses dados permitiram que os autores concluíssem que a refletância da copa a $800 \mathrm{~nm}$ pode fornecer uma indireta estimativa de HLAI.

Canteri (1998), estudando o patossistema feijão/mancha angular (Phaeoisariopsis griseola) em condições de folhas destacadas, pode observar que 
quanto maior o nível de severidade, maior foi a refletância nos comprimentos de onda de $460,510,560,660$ e $710 \mathrm{~nm}$ e menor em 760 e $810 \mathrm{~nm}$. A nível de campo, o autor não encontrou um comprimento de onda que pudesse ser usado para estimar apenas a severidade de doença. Por outro lado, os índices de área foliar (LAI) obtidos para os cultivares Carioca e Iapar 44, em duas épocas de plantio e sob dois tratamentos de controle da mancha angular, relacionaram-se bem com refletância a $810 \mathrm{~nm}\left(\mathrm{R}_{810}\right)$. Para o índice de área foliar sadia (HLAI), o autor obteve boas correlações com refletância em $810 \mathrm{~nm}\left(\mathrm{R}^{2}=84,7 \%\right)$ e com a diferença normalizada, usando 810 e 660 $\mathrm{nm}\left(\mathrm{ND}_{810,660}\right)\left(\mathrm{R}^{2}=86,6 \%\right)$. Para absorção de área foliar sadia por unidade de tempo (HRI), encontrou-se melhor relação com a $\mathrm{ND}_{810,610}\left(\mathrm{R}_{2}=82,6 \%\right)$.

Outras utilidades têm sido atribuídas ao radiômetro de múltiplo espectro, como quantificar diferenças em stands de trigo (Aase \& Siddoway, 1980), monitorar o desenvolvimento de ferrugem em cereais (Sharp et al., 1985) e avaliar a eficiência de fungicidas no controle de doenças (Nutter Jr. et al., 1990). 


\section{ANTRACNOSE DO FEIJOEIRO: RELAÇÃO ENTRE DOENÇA, ÁREA FOLIAR SADIA E PRODUÇÃO}

\subsection{RESUMO}

Três experimentos de campo foram conduzidos para se investigarem as relações entre severidade de doença $(X)$, desfolha, área sob a curva de progresso de doença (AUDPC), índice de área foliar sadia (HLAI), radiação interceptada pela área foliar sadia por unidade de tempo (HRI), duração da área foliar sadia (HAD), absorção da área foliar sadia (HAA) e produção de feijoeiro, cultivar 'Carioca' infectado com Colletotrichum lindemuthianum. Pôde-se encontrar relação entre severidade de doença (AUDPC) e produção. De modo geral, desfolha, unicamente, não se relacionou à produção. Entretanto, melhores relações foram observadas quando produção foi relacionada com $\mathrm{HAD}$ e HAA. Para altas produções sempre se observaram altos valores de $\mathrm{HAD}$ e HAA. A relação entre produção e $\mathrm{HAD}$ foi linear para os três experimentos $\left(51,60<\mathrm{R}^{2}<69,80 \%, \mathrm{P}<0,001\right)$. A relação entre produção e $\mathrm{HAA}$, em apenas um dos experimentos foi melhor explicada pelo modelo exponencial do que pelo linear; entretanto, modelos lineares ajustaram-se bem a todos os ensaios $\left(27,40<\mathrm{R}^{2}<66,97 \%, \mathrm{P}<0,001\right)$. Modelos de ponto crítico, usando HRI para estimar produção, foram desenvolvidos para diferentes estádios de crescimento da cultura. Os coeficientes angulares dessa relação tenderam a estabilizar-se a partir do estádio $R_{5}$, $\left(1,477 \pm 0,07 \mathrm{~g} \mathrm{MJ}^{1}\right)$ independentemente da época de plantio. Comportamento 
semelhante foi obtido para a relação entre produção e HLAI, com estabilização em $5,748 \pm 0,31$. HRI é proposta como uma variável explanatória para um sistema transportável de manejo de doença.

\subsection{INTRODUÇÃO}

A antracnose do feijoeiro (Phaseolus vulgaris L.), causada por Colletotrichum lindemuthianum (Sacc. \& Magnus) Br. \& Cav., apresenta distribuição por todo o mundo (Schwartz, 1994). Essa doença é uma das mais importantes, afetando as cultivares suscetiveis estabelecidas em localidades com temperaturas moderadas a baixas e alta umidade relativa (Rava et al., 1998). O patógeno causa lesões nas folhas, pecíolos, caules e vagens, podendo promover severa desfolha quando ocorre a completa necrose foliar. Os danos ocasionados pela doença podem ser de até $100 \%$, quando são semeadas sementes infectadas e as condições de ambiente são favoráveis (Rava et al., 1998; Sartorato, 1988). Um sistema de manejo de doenças que seja transportável no tempo e no espaço é necessidade urgente, para proporcionar um uso mais racional de defensivos agrícolas.

O desenvolvimento e implementação de sistemas de manejo de pragas e doenças requer informações precisas e acuradas sobre os danos causados por pragas e patógenos. Dano é definido como qualquer redução quantitativa ou qualitativa na produção que resulta de uma injúria. Injúria é qualquer sintoma ou sinal, visivel ou mensurável causado por uma praga ou patógeno (Zadoks, 1985). Tradicionalmente, para quantificar o efeito de uma doença sobre uma cultura, modelos como os de ponto crítico, múltiplos pontos ou modelos integrais (Madden \& Nutter Jr., 1995) têm sido usados. Modelos de ponto crítico ou de múltiplos pontos, geralmente, relacionam produção com severidade de doença num único estádio de crescimento da cultura ou 
em múltiplos estádios de crescimento, respectivamente. Modelos integrais, geralmente, relacionam produção com a área sob a curva de progresso de doença (AUDPC). Entretanto esses modelos nem sempre são úteis para a previsão de danos. A falta de transportabilidade desses modelos para outra estações ou locais deve-se, principalmente, à grande variação na produção das plantas livres de doenças e também devido à fraca e indireta relação entre produção e doença (Bergamin Filho et al., 1997).

Produção $\left(Y, \mathrm{~g} \mathrm{~m}^{-2}\right)$ é função da área foliar da cultura ou de seu índice de área foliar (LAI) num dado tempo: $Y=f[\mathrm{LAI}(t)]$ (Watson, 1947). Mais precisamente, produção pode ser expressa em função do LAI integrado através da estação de crescimento: $Y=f(\mathrm{LAD}$ ), no qual LAD é a duração da área foliar (dias) (Watson, 1947). Monteith (1977) refinou os conceitos acima, sugerindo que produção é função da radiação interceptada (RI, $\mathrm{MJ} \mathrm{m}^{-2}$ ) pela copa das plantas de uma cultura, num determinado tempo: $Y=f[\mathrm{RI}(t)]$. Mais precisamente, produção pode ser expressa como uma função de RI integrada através da estação de crescimento da cultura: $Y=f($ LAA), na qual LAA é a absorção da área foliar $\left(\mathrm{MJ} \mathrm{m}^{-2}\right)$ (Monteith, 1977). Radiação interceptada e radiação absorvida, embora sejam conceitualmente diferentes, têm seus valores muitos próximos e podem ser empregadas, para fins práticos, indistintamente (Bergamin Filho et al., 1997).

Waggoner \& Berger (1987) adaptaram os conceitos de Watson (1947) e Monteith (1977) para o contexto da fitopatologia, obtendo o índice de área foliar sadia (HLAI) num dado tempo: HLAI = LAI $(1-X)$, em que $X$ é a de severidade de doença em proporção. Com base neste conceito foi definida a duração da área foliar sadia (HAD, dias) e a absorção da área foliar sadia (HAA, $\mathrm{MJ} \mathrm{m}^{-2}$ ). Deste modo, produção pode estar relacionada com HLAI integrado através da estação de crescimento da cultura $(Y=f(\mathrm{HAD}))$ e com a radiação interceptada pela área foliar sadia por unidade de tempo (HRI), em que HRI $=\mathrm{RI}(1-X)$ integrado através da estação de crescimento $(Y=f(\mathrm{HAA}))$ (Bergamin Filho et al., 1997). Estas relações também podem ser descritas como: $Y=\int \operatorname{RUE}(t) \mathrm{RI}(t)[1-\mathrm{X}(t)] d t$, em que RUE $(t)\left(\mathrm{g} \mathrm{MJ}^{1}\right)$ é a 
eficiência do uso da radiação, que pode ser considerada como: $Y=\operatorname{RUE} \int \mathrm{RI}(t)[1-$ $\mathrm{X}(t)] d t$, caso RUE seja constante durante a estação de cultivo (Bergamin Filho et al., 1997). RI pode ser estimada como o produto da radiação solar incidente (I, $\mathrm{MJ} \mathrm{m}^{-2}$ ) e proporção da radiação que é interceptada pela copa das plantas (Monteith \& Unsworth, 1990). Baseada na lei de Beer, esta proporção é função do LAI, então, RI =I (1 - exp ($K \mathrm{LAI}$ )), em que $K$ é o coeficiente de extinção da cultura que é constante. Deste modo, se RUE é considerado constante e $(1-X)$ é a proporção de área foliar sadia, produção pode ser relacionada com RI pela equação (Waggoner \& Berger, 1987): $Y=\operatorname{RUE}(t) \int I$ $(t)\{1-\exp [-K \operatorname{LAI}(t)]\}[1-\mathrm{X}(t)] d t$.

Essa metodologia sugere que a produção é relacionada diretamente com as variáveis $\mathrm{HLAI}, \mathrm{HRI}, \mathrm{HAD}$ e HAA, ao passo que doença, quantificada por meio de escalas diagramáticas, relaciona-se indiretamente com produção (Madden \& Nutter Jr., 1995). Recentemente, vários trabalhos têm empregado essa metodologia em patossistemas das principais doenças do feijoeiro (Lopes et al., 1994; Nunes \& Bergamin Filho, 1996; Carneiro, 1995; Iamauti, 1995; Godoy, 1995; Canteri et al., 1998). Tais trabalhos não consideraram a desfolha promovida pelo patógeno no hospedeiro, e conseqüentemente acredita-se a doença foi subestimada (Godoy, 1995). Tal fato pode explicar a falta de relação entre doença e produção.

O objetivo deste trabalho foi comparar a metodologia baseada na radiação absorvida pela área foliar sadia num dado tempo, suas integrais e suas relações com produção, com a metodologia que relaciona severidade de doença com produção. Em ambas as situações foram comparadas, tais relações, quando se considerou ou não a desfolha promovida pelo hospedeiro. Secundariamente, baseando-se nos resultados obtidos com a antracnose do feijoeiro, procurou-se propor um sistema de manejo de doenças em que a tomada de decisão baseou-se em HRI de acordo com a proposta de Bergamin Filho et al. (1997) para mancha angular. 


\subsection{MATERIAL E MÉTODOS}

\subsubsection{Experimentos de campo}

Três experimentos foram conduzidos durante o ano de 1997, com a cultivar 'Carioca'. Esses ensaios foram conduzidos na Estação Experimental Nova Fazenda Hokko, situada na Rodovia SP $143, \mathrm{Km} 8,5$, município de Pereiras, SP (23으, $60^{\circ} \mathrm{W}$, altitude de $479 \mathrm{~m}$ ). O primeiro experimento foi semeado em 17 de abril de 1997, e foi denominado de campo 5. Os demais foram plantados 30 e 60 dias após o plantio do primeiro, e foram denominados de campo 6 e campo 7, respectivamente.

Em todos os ensaios, utilizou-se do mesmo delineamento experimental, de blocos ao acaso, com cinco tratamentos e três repetições. Cada parcela de $12 \mathrm{~m}^{2}$ possuia quatro linhas de plantio, com seis metros de extensão. O espaçamento entre linhas foi de $0,5 \mathrm{~m}$, procurando-se obter uma densidade de 12 plantas por metro linear. A manutenção dos experimentos deu-se por meio de práticas culturais convencionais, utilizadas em campos comerciais, incluindo plantio, adubações, irrigações quando necessários, e pulverizações com os inseticidas metamidofós e cartap. Essas pulverizações objetivaram deixar os experimentos livres da interferência de pragas e de ferrugem.

Quando os plantios atingiram o estádio $V_{3} / V_{4}$ (Michaels, 1994), procedeu-se à inoculação de todas as parcelas. Para tanto, utilizou-se de isolados de Colletotrichum lindemuthianum, obtidos junto ao Instituto Agronômico do Paraná e a Universidade Federal de Lavras. Esses isolados foram multiplicados em meio de ágarvagem (Benhamon et al., 1991), mantidos por 14 dias sob escuro constante e temperatura de $21^{\circ} \mathrm{C}$. Decorrido esse periodo, obteve-se uma suspensão de esporos, padronizada em $10^{6}$ esporos $/ \mathrm{ml}$. Essa suspensão foi pulverizada sobre as plantas, utilizando-se pulverizador costal de pressão constante, $40 \mathrm{Lb} / \mathrm{pol}^{2}$, aplicando-se $130 \mathrm{ml}$ da suspensão nas duas fileiras centrais de cada parcela. A inoculação foi realizada 
sempre após as 20:00 h, sendo previamente aspergida água destilada sobre as plantas, do mesmo modo, utilizado para a inoculação. Esse procedimento objetivou proporcionar molhamento foliar até que fosse atingido o ponto de orvalho $\mathrm{e}$ conseqüentemente ocorresse molhamento foliar natural. Isto deu-se em função da impossibilidade de colocar câmara úmida em todo o ensaio.

Para estabelecer diferentes severidades de doença, realizaram-se pulverizações com fungicida à base de trifenil acetato de estanho, em dosagem de 0,2 $\mathrm{kg} / \mathrm{ha}$, em diferentes épocas. No tratamento 1 as pulverizações foram iniciadas uma semana após a inoculação e de freqüência semanal, sendo considerado como parcela controle sensu Lopes et al. (1994). No tratamento 2 a primeira pulverização foi feita no estádio $R_{5}$ (Michaels, 1994), e repetida uma única vez após 14 dias. No tratamento 3 realizou-se pulverização no estádio $R_{5}$ (Michaels, 1994). No tratamento 4 a pulverização foi realizada 14 dias após ter sido atingido o estádio $\mathrm{R}_{5}$ (Michaels, 1994). No tratamento 5 , testemunha, não se realizou controle da antracnose do feijoeiro.

\subsubsection{Crescimento do hospedeiro, severidade de doença e produção}

Crescimento do hospedeiro, severidade de doença e produção foram avaliados nas duas fileiras centrais de cada parcela. Em cada parcela, foram marcadas 4 plantas com fita plástica colorida no estádio $V_{3} / V_{4}$ (Michaels, 1994). Procurou-se selecionar plantas com tamanho e vigor semelhantes. Nestas plantas marcaram-se todas as folhas, que foram surgindo com o auxilio de uma etiqueta de papel numerada, e embebida em parafina. As folhas foram numeradas objetivando-se quantificar a desfolha promovida pelo patógeno.

A área foliar $\left(\mathrm{LA}, \mathrm{cm}^{2}\right)$ de todas as folhas de cada planta marcada foi estimada semanalmente, iniciando-se no estádio $V_{3} / V_{4}$ (Michaels, 1994). Para isto, a maior largura do folíolo central de cada folha $(L, \mathrm{~cm})$ foi medida com o auxílio de uma régua. A área foliar foi estimada a partir da relação empírica (Bassanezi, 1995): 


$$
\mathrm{LA}=3,03 L^{1,87}, \mathrm{R}^{2}=88 \% \text {. }
$$

A avaliação da severidade da antracnose do feijoeiro foi realizada simultaneamente à avaliação de área foliar com o auxilio de uma escala diagramática de severidade (Godoy et al., 1997), com a qual foi avaliada a percentagem média de severidade para os três folíolos de todas as folhas das plantas marcadas.

A desfolha do hospedeiro foi quantificada entre avaliações consecutivas. Para tanto, quando folíolos ou folhas atingiam $100 \%$ de necrose ou apresentavam-se caídos em função do patógeno, suas respectivas áreas foliares foram consideradas como desfolha. Estes dados foram computados para obtenção da área foliar total das plantas. Em seguida, os dados de desfolha foram utilizados para cálculo da percentagem de desfolha (DF, \%) tomando-se como referência a área foliar total das plantas:

$$
\mathrm{DF}=(\text { Área desfolhada } / \text { Área foliar total }) * 100
$$

A produção foi determinada para cada planta marcada, ao final do ciclo da cultura, pesando-se as sementes com $12 \%$ de umidade. Os resultados foram expressos em $g$ planta ${ }^{-1}$.

\subsubsection{Variáveis integrais}

A AUDPC para cada planta marcada foi calculada por integração trapezoidal:

$$
\mathrm{AUDPC}=\sum_{i=1}^{n-1}\left[\left(X_{i}+X_{i+1}\right) / 2\right]\left(t_{i+1}-t_{i}\right)
$$

Em que $X$ é a severidade média da doença (porcentagem), $X_{\mathrm{i}}$ é severidade no tempo $t_{i} ; n$ é o número de avaliações e $\left(t_{i+1}-t_{i}\right)$ é o intervalo entre duas avaliações consecutivas. Foram realizados dois cálculos da AUDPC. Um deles foi realizado, quando se considerou a desfolha promovida pelo patógeno para estimativa de $X$. O outro foi realizado não considerando tal desfolha. 
Os valores de índice de área foliar (LAI) de cada planta foram obtidos dividindo a área foliar de cada planta, em cada avaliação, pela área ocupada por cada planta $\left(0,0416 \mathrm{~m}^{2}\right)$. A duração de área foliar sadia (HAD) foi calculada pela fórmula

$$
\mathrm{HAD}=\sum_{i=1}^{n-1}\left\{\left[L A I_{i}\left(1-X_{i}\right)+L A I_{i+1}\left(1-X_{i+1}\right)\right] / 2\right\}\left(t_{i+1}-t_{i}\right)
$$

Em que $\mathrm{LAI}_{\mathrm{i}}$ é o índice de área foliar no tempo $t_{i} \mathrm{O}$ valor do índice de área foliar sadio (HLAI) para cada data de avaliação foi calculado como $\mathrm{HLAI}=\mathrm{LAI}(1-X)$.

Os valores de radiação interceptada $\left(\mathrm{RI}_{\mathrm{i}}\right) \mathrm{em} \mathrm{MJ} \mathrm{m}^{-2}$ foram calculados como:

$$
\mathrm{RI}_{i}=I_{i}\left[1-\exp \left(-k \mathrm{LAI}_{i}\right)\right]
$$

em que $I_{i}$ é a média de radiação solar incidente $\left(\mathrm{MJ} \mathrm{m}^{-2}\right)$ no período $\left(t_{i+1}-t_{i}\right)$ e $k$ é o coeficiente de extinção; usou-se $k=0,7$ (Miglioranza, 1992; Bergamin Filho et al., 1997). O valor da absorção da área foliar sadia (HAA) $\mathrm{em} \mathrm{MJ} \mathrm{m}^{-2}$ foi calculado como:

$\mathrm{HAA}=\sum_{i=1}^{n-1} I_{i}\left(\left\{\left(1-X_{i}\right)\left[1-\exp \left(-k L A I_{i}\right)\right]+\left(1-X_{i+1}\right)\left[1-\exp \left(-k L A I_{i+1}\right)\right]\right\} / 2\right)\left(t_{i+1}-t_{i}\right)$

Os valores de HRI ( $M J ~ m^{-2}$ ), para cada data de avaliação, foram calculados pela fórmula $\mathrm{HRI}=\mathrm{RI}(1-X)$. A radiação solar incidente $(I)$ foi medida por uma estação meteorológica computadorizada situada a $500 \mathrm{~m}$ da área experimental.

\subsubsection{Análise dos dados}

As relações de produção com HAD e com HAA foram obtidas por regressão linear usando-se o programa STATISTICA (StatSoft, Tulsa, OK). Também foi utilizada, para as relações de produção com HLAI e HRI, a regressão linear forçando-se sua passagem através da origem. Os coeficientes angulares dessas retas foram plotados em função dos estádios de crescimento do feijoeiro; em seguida, obtiveram-se curvas por regressão não-linear usando-se o programa PlotIT for Windows (Scientific Programming Enterprises, Haslsett, MI). 


\subsection{RESULTADOS E DISCUSSÃO}

\subsubsection{Radiação solar, doença e produção}

Os valores médios de radiação solar durante a condução de cada experimento variou de $13,58 \mathrm{MJ} \mathrm{m}^{-2}$ por dia, no campo 5, a $14,49 \mathrm{MJ} \mathrm{m}^{-2}$ por dia, no campo 7 (Tabela 1). As diferentes épocas de aplicação do fungicida para controle de Colletotrichum lindemuthianum resultaram em parcelas com bastante variação na severidade em cada experimento. Plantas totalmente sadias não foram encontradas em nenhum dos experimentos, devendo-se isto ao início dos tratamentos uma semana após a inoculação do campo. Entretanto, plantas com severas infecções, mais de $50 \%$ de severidade, foram encontradas em todos os ensaios (Tabela 1 e Figura 1). A média de produção variou de $3,6 \mathrm{~g}_{\text {planta }}{ }^{-1}$ no campo 5 a $24,52 \mathrm{~g}$ planta $^{-1}$ no campo 7 (Tabela 1).

Tabela 1 - Radiação solar, severidade de antracnose do feijoeiro, área sob a curva de progresso de doença (AUDPC) e produção para três experimentos* conduzidos em Pereiras, SP, 1997.

\begin{tabular}{cccccccc}
\hline \multirow{2}{*}{$\begin{array}{c}\text { Experi- } \\
\text { mento }\end{array}$} & Radiação solar $\left(\mathrm{MJ} \mathrm{m}^{-2} /\right.$ dia $)$ & \multicolumn{2}{c}{ Severidade $(\%)$} & \multicolumn{2}{c}{ AUDPC } & \multicolumn{2}{c}{ Produção $\left(\mathrm{g}_{\text {planta }}{ }^{-1}\right)$} \\
\cline { 2 - 8 } & Média $\pm \mathrm{SE}^{* *}$ & Máximo & Média $\pm \mathrm{SE}$ & Máximo & Média $\pm \mathrm{SE}$ & Máximo & Média $\pm \mathrm{SE}$ \\
\hline Campo 5 & $13.58 \pm 0.077$ & 100 & $\mathbf{8 7 . 6 6 \pm 0 . 5 3}$ & 2804.71 & $\mathbf{1 8 1 0 . 4 6 \pm 1 6 . 1 3}$ & 20.3 & $3.60 \pm 0.16$ \\
Campo 6 & $13.90 \pm 0.079$ & 100 & $69.24 \pm 0.82$ & 1754.50 & $786.72 \pm 14.24$ & 62.0 & $18.35 \pm 0.41$ \\
Campo 7 & $14.49 \pm 0.078$ & 100 & $33.47 \pm 0.67$ & 831.90 & $361.38 \pm 6.39$ & 44.6 & $24.52 \pm 0.28$ \\
\hline
\end{tabular}

Média ( \pm erro padrăo) para 60 plantas em cada experimento.

" SE = erro padrăo da amostra

Nos três ensaios realizados, o decréscimo na produção esteve associado em maior ou menor grau com um aumento na AUDPC, que foi razoavelmente descrito 
pelo modelo exponencial $Y=b_{1} \exp \left(b_{2}\right.$ AUDPC), no qual $Y$ é a produção (g planta ${ }^{-1}$ ) (Tabela 2).

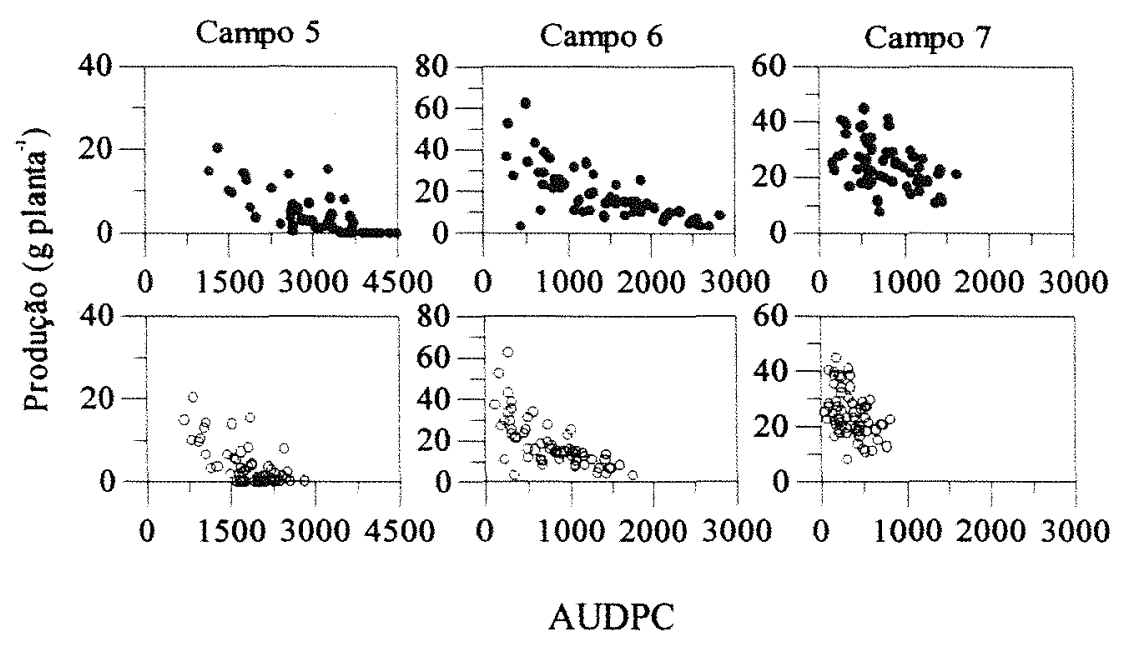

Figura 1 - Produção $\left(\mathrm{g}_{\text {planta }}{ }^{-1}\right)$ versus área sob a curva de progresso de doença, para plantas individuais de feijão infectadas com antracnose em três experimentos (60 plantas por experimento), conduzidos em Pereiras, SP, 1997. Círculos cheios representam avaliações onde foi considerada desfolha promovida pelo patógeno para cálculo da AUDPC. Círculos vazios representam avaliações onde não se considerou desfolha.

Em todos os experimentos, o patógeno promoveu desfolha nas plantas de feijoeiro. A média das percentagens de desfolha ( \pm erro padrão da amostra) foram de $80,97 \pm 0,67,68,72 \pm 0,81$ e $31,12 \pm 0,65$ para os campos 5,6 e 7 , respectivamente (Figura 2). No Campo 5, a produção esteve associada ao aumento da desfolha. Essa relação foi razoavelmente descrita pelo modelo exponencial $Y=b_{1} \exp \left(b_{2} \mathrm{DF}\right)$, Figura 2 , no qual $Y$ é a produção $\left(\mathrm{g}\right.$ planta $\left.{ }^{-1}\right), b_{I}=51,27, b_{2}=-0,03705$ e DF - desfolha $\left(\mathrm{R}^{2}=\right.$ 
60,33). O mesmo modelo aplicado aos outros experimentos produziu valores de $\mathrm{R}^{2}$ baixos, não evidenciando relação entre desfolha e produção.

Tabela 2 - Varáveis $b_{1}$ e $b_{2}$ para o modelo exponencial $\left(Y=b_{1} \exp \left(b_{2}\right.\right.$ AUDPC)), obtido entre produção ( $\left(\right.$ planta $\left.^{-1}\right)$ e AUDPC, para feijoeiros infectados com antracnose, em três experimentos. Os modelos foram ajustados considerando-se ou não a desfolha promovida pelo patógeno, em três experimentos conduzidos em Pereiras, SP, 1997.

\begin{tabular}{ccccc}
\hline Experimento & Desfolha & $b_{1} \pm \mathrm{SE}^{*}$ & $b_{2} \pm \mathrm{SE}$ & $\mathrm{R}^{2}$ \\
\hline Campo 5 & Sim & $49,61 \pm 10,71$ & $-0,0009 \pm 0,0001$ & 59,82 \\
Campo 5 & Não & $55,47 \pm 14,98$ & $-0,0017 \pm 0,0002$ & 51,53 \\
Campo 6 & Sim & $47,19 \pm 4,99$ & $-0,0007 \pm 0,0001$ & 52,89 \\
Campo 6 & Não & $42,36 \pm 4,16$ & $-0,0012 \pm 0,0002$ & 51,73 \\
Campo 7 & Sim & $34,12 \pm 3,06$ & $-0,0004 \pm 0,0001$ & 20,47 \\
Campo 7 & Não & $32,21 \pm 2,66$ & $-0,0007 \pm 0,0002$ & 17,71 \\
\hline
\end{tabular}

* SE $=$ erro padrão da amostra

\subsubsection{HAD e HAA}

A relação entre produção e $\mathrm{HAD}$ para todas as plantas marcadas foi realizada para cada um dos três experimentos (Figura 3 e Tabela 3). Em todos os casos, a produção aumentou linearmente com $\operatorname{HAD}(\mathrm{P}<0,001)$. Os coeficientes de determinação $\left(R^{2}\right)$ foram bastante altos para este tipo de experimento e variaram de 51,60 a 80,97 . As retas de regressão foram significativamente diferentes $(P<0,05)$; entretanto, a análise conjunta dos três experimentos permitiu obter uma reta com ajuste 
melhor aos dados $\left(\mathrm{R}^{2}=82,0 \%\right)$ : Produção $=-5,60924+0,139636 *$ HAD $($ Tabela $3 \mathrm{e}$ Figura 3).

Nos três experimentos, a produção aumentou juntamente com HAA $(\mathrm{P}<0,001)$ (Figura 3 e Tabela 3). Relações lineares foram satisfatórias em todos os experimentos $\left(R^{2}\right.$ de 27,41 a $66,96 \%$ ). Entretanto, para o campo 6, o modelo exponencial apresentou melhor ajuste: Produção $=0,3316 \exp (0,005339 * \mathrm{HAA}), \mathrm{R}^{2}=$ $75,84 \%$. As retas de regressão foram significativamente diferentes $(\mathrm{P}<0.05)$; entretanto, a análise conjunta dos três experimentos permitiu obter uma reta com ajuste melhor aos dados $\left(\mathrm{R}^{2}=67,43 \%\right.$ ): Produção $=-16,9634+0,0501841 *$ HAA (Tabela 3 e Figura 3).

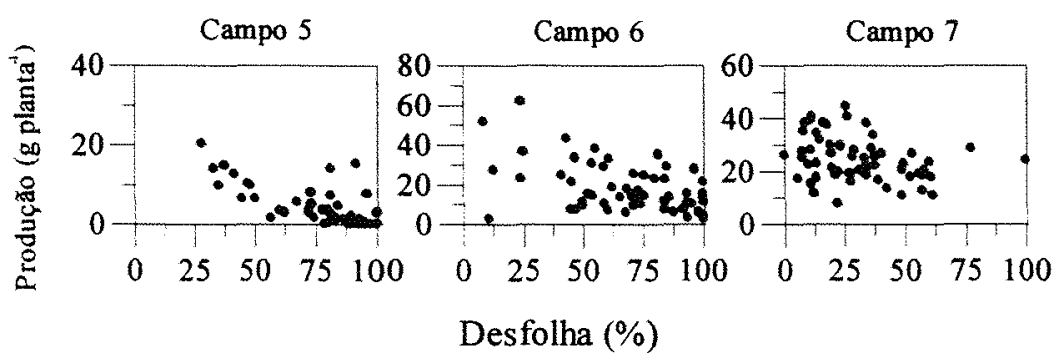

Figura 2 - Produção $\left(\mathrm{g}\right.$ planta $^{-1}$ ) versus desfolha, para plantas individuais de feijão infectadas com antracnose em três experimentos (60 plantas por experimento), conduzidos em Pereiras, SP, 1997. 
Tabela 3 - Valores de interseção e coeficientes angulares ( \pm erro padrão) das retas de regressão entre produção $\left(\mathrm{g}\right.$ planta $\left.^{-1}\right)$ e duração da área foliar sadia (HAD, dias) e entre produção e absorção da área foliar sadia (HAA, $\mathrm{MJ} \mathrm{m}^{-2}$ ) em três experimentos conduzidos em Pereiras, SP, 1997.

\begin{tabular}{|c|c|c|c|c|c|c|}
\hline \multirow[b]{2}{*}{ Experimento } & \multicolumn{3}{|c|}{ HAD } & \multicolumn{3}{|c|}{$\overline{\mathrm{HAA}}$} \\
\hline & Interseção & $\begin{array}{c}\text { Coeficiente } \\
\text { angular }\end{array}$ & $\mathrm{R}^{2}$ & Interseção & $\begin{array}{l}\text { Coeficiente } \\
\text { angular }\end{array}$ & $\overline{R^{2}}$ \\
\hline Campo 5 & $4,9732 \pm 0,8190$ & $0,1105 \pm 0,0095$ & 69,80 & $-7,9777 \pm 1,1289$ & $0,0277 \pm 0,0026$ & 66,97 \\
\hline Campo 6 & $-7,0346 \pm 1,7545$ & $0,1529 \pm 0,0097$ & 80,97 & $-31,1125 \pm 6,4551$ & $0,0667 \pm 0,0086$ & 51,03 \\
\hline Campo 7 & $5,2967 \pm 2,5616$ & $0,0916 \pm 0,011$ & 51,60 & $-12,4169 \pm 7,9479$ & $0,0472 \pm 0,0101$ & 27,41 \\
\hline Comum & $-5,6092 \pm 0,8405$ & $0,1396 \pm 0,0049$ & 82,00 & $-16,9634 \pm 1,7727$ & $0,0502 \pm 0,0026$ & 67,43 \\
\hline
\end{tabular}

Regressáo obtida por meio da análise conjunta dos dados três experimentos

\subsubsection{HLAI E HRI}

As relações entre produção e valores individuais de HLAI e HRI, nos principais estádios de crescimento do feijoeiro, foram determinadas para os três experimentos (Tabela 4). Os coeficientes angulares das retas de regressão entre produção e HLAI, com passagem forçada através da origem, iniciaram com valores muito variáveis no estádio de crescimento $\mathrm{V}_{3} / \mathrm{V}_{4}(6,30,50,25$ e 62,62 para os campos 5,6 e 7 respectivamente) e tenderam a se estabilizar ao redor de 5,748 $\pm 0,31$ (média \pm erro padrão) entre os estádios de crescimento $R_{5}$ e $R_{8}$ (Figura 4). A função beta ajustouse aos coeficientes angulares obtidos nos três experimentos:

$S=(68,6446)^{*}\left(\mathrm{GS}^{(-1,390597)}\right)^{*}(7,1-\mathrm{GS})^{(-0,2921477)}$ com $\mathrm{R}^{2}=54,6 \%$ no qual $S$ é o coeficiente angular da reta de regressão obtida entre produção e HLAI, e GS são os estádios de crescimento do feijoeiro $\left(V_{3}=1 V_{4}=2 ; R_{5}=3 ; R_{6}=4 ; R_{7}=5 ; R_{8}=6\right.$ e $R_{9}$ $=7)$. 
A relação linear entre produção e HRI, com passagem forçada através da origem também apresentou coeficientes angulares variáveis no estádio $V_{3} / V_{4}(0,68$, 6,99 e 8,30 para os campos 5, 6 e 7 respectivamente). De modo semelhante ao obtido na relação de HLAI com produção, os coeficientes angulares das retas de regressão entre produção e HRI, tenderam a estabilizar-se por volta de $1,477 \pm 0,07$ (média \pm erro padrão) entre os estádios de crescimento $R_{5}$ e $R_{8}$ (Figura 4 ). A função beta ajustada a esses coeficientes foi: $S=(8,3273)^{*}\left(\mathrm{GS}^{(-1,03918)}\right) *(7,1-\mathrm{GS})^{(-0,2472413)}, \operatorname{com} \mathrm{R}^{2}=44,3 \%$.
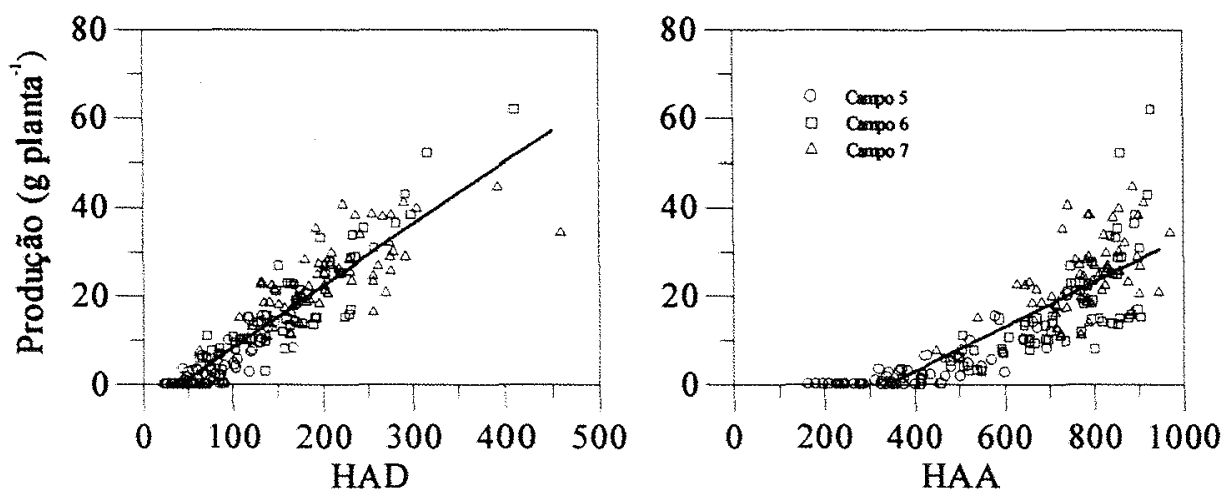

Figura 3 - Produção versus duração da área foliar sadia (HAD, dias) e absorção da área foliar sadia (HAA, $\mathrm{MJ} \mathrm{m}^{-2}$ ) para plantas de feijão infectadas com antracnose, em três experimentos conduzidos em Pereiras, SP, 1997. Reta obtida por meio da análise conjunta dos dados dos três experimentos. 
$\mathrm{Na}$ Tabela 4, nota-se que para o campo 5, nos estádios de crescimento $V_{3}, V_{4}$ e $R_{5}$, os coeficientes angulares das regressões entre HRI apresentaram-se muito discrepantes dos obtidos para os campos 6 e 7. Considerando-se que estes valores são muito semelhantes nesses dois últimos ensaios, pode-se cogitar que a discrepância dos valores encontrados no campo 5 , entre os estádios de crescimento de $V_{3}$ e $R_{5}$, deve-se à severa infeç̧ão do patógeno que se verificou nessa ocasião, obtida por meio da inoculação. Nesta inoculação, obtiveram-se plantas totalmente queimadas pelo patógeno, que só tiveram seus respectivos HLAI restaurados após brotações e quando estas foram protegidas pelo fungicida. Deste modo, sendo a situação bastante atípica, optou-se por verificar qual o comportamento da função beta ajustada aos dados quando se desprezaram os valores dos coeficientes angulares das retas de regressão entre HRI e HLAI com produção, nos estádios de $V_{3}, V_{4}$ e $R_{5}$. Por meio dessa metodologia conseguiu-se melhor ajuste da função aos dados (Figura 5):

$S=(89,1219)^{*}\left(\mathrm{GS}^{(-1,48879)}\right) *(7,1-\mathrm{GS})^{(-0,2396)}, \mathrm{com} \mathrm{R}^{2}=92,98 \%$ e

$S=(11,6462)^{*}\left(\mathrm{GS}^{(-1,1981)}\right) *(7,1-\mathrm{GS})^{(-0,2262)}$, com $\mathrm{R}^{2}=94,13 \%$, para os coeficientes angulares das retas de regressão entre produção e HALI e HRI, respectivamente. $S$ e GS apresentam a mesma definição descrita acima.

Nos três experimentos descritos neste trabalho, foi encontrada relação entre produção e AUDPC (Figura 1). Por outro lado, a falta de relação entre produção e AUDPC é bastante comum para patossistemas do feijoeiro (Nunes \& Bergamin Filho, 1996; Carneiro, 1995; Iamauti, 1995; Godoy, 1995). Entretanto, apesar de menos freqüente, relações entre AUDPC e produção também constam na literatura (Canteri, 1998). A falta de relação entre AUDPC e produção é atribuída por Bergamin Filho et al. (1997) a três fatores principais: $i$ ) intensa desfolha promovida pelo patógeno; $i$ ) falta de estimativa de desfolha iii) ao hábito de crescimento indeterminado do hospedeiro. Neste trabalho, procurou-se explorar a desfolha do hospedeiro para se verificar a influência de tal fator na relação. Observou-se que, mesmo sem se considerar a desfolha promovida no hospedeiro, já se encontravam relações entre produção e AUDPC. Entretanto, a incorporação da desfolha para cálculo da AUDPC 
melhorou tais relações (Tabela 2). As melhores relações encontradas justificam tal quantificação em ensaios que visem a estabelecer funções de dano.

A relação entre produção e AUDPC observada nos três experimentos foi razoavelmente descrita pelo modelo exponencial. Munford \& Norton (1987) atribuíram a essa relação o nome de curva do "tipo I". Johnson (1987) comenta que curvas deste tipo indicam que a eficiência do uso da radiação (RUE), pelos tecidos verdes, aparentemente sadios, é afetada pelo patógeno. Deste modo, doenças deste grupo causam não apenas declínio no HLAI, e conseqüentemente em HRI, mas também. diminuem RUE. Num recente trabalho, Bassanezi et al. (1997) verificaram que a eficiência no uso da radiação por plantas de feijão infectadas com Colletotrichum lindemuthianum apresentam drástica redução. Folhas com 5 a $10 \%$ de severidade apresentam $50 \%$ de redução na fotossíntese líquida da folha. Deste modo, os resultados de Bassanezi et al. (1997) estão de acordo com o tipo de curva obtido neste trabalho.

A desfolha, quando considerada isoladamente, demonstrou relação com produção apenas para um dos experimentos, o que indica lógica incerta. Conforme nos lembra Watson (1947), produção é função do índice de área foliar da cultura, e seria surpreendente encontrar uma sólida relação entre produção e desfolha.

A relação linear entre produção e $\mathrm{HAD}$, obtida em todos os ensaios descritos neste trabalho (Tabela 3 e Figura 3) é contrária à relação não-linear, obtida pelo modelo de Gompertz, originalmente proposta por Waggoner \& Berger (1987) para o patossistema amendoim/Cercosporidium personatum. Essa relação foi confirmada para o mesmo patossistema por Aquino et al. (1992). No caso do feijoeiro cultivar 'Carioca', a produção aumentou linearmente e não assintoticamente com o aumento da área foliar. Essa relação pode ser atribuida às características peculiares dessa cultivar, como a formação de vagens na base de cada folha $\mathrm{e}$ ao hábito de crescimento indeterminado (Bergamin Filho et al., 1997). Essa linearidade também foi encontrada para outros patossistemas. No caso específico de feijoeiro, ela foi obtida pela ferrugem, Uromyces appendiculatus (Iamauti, 1995), mancha angular Phaeosisariopsis griseola 
(Carneiro, 1995; Godoy, 1995; Bergamin Filho et al., 1997; Canteri et al., 1998) e antracnose (Nunes \& Bergamin Filho, 1996).

Tabela 4 - Coeficientes angulares ( \pm erro padrão) das retas de regressão (passagem forçada através da origem) entre produção $\left(\mathrm{g}_{\text {planta }}{ }^{-1}\right)$ e índice de área foliar sadia (HLAI) e entre produção e radiação interceptada pela área foliar sadia (HRI, $\mathrm{MJ} \mathrm{m}^{-2}$ ), em diferentes estádios de crescimento do feijoeiro, em três experimentos conduzidos em Pereiras, SP, 1997.

\begin{tabular}{ccccccc}
\hline & \multicolumn{5}{c}{ HLAI } & \multicolumn{3}{c}{ HRI } \\
\cline { 2 - 7 } $\mathrm{GS}^{*}$ & Campo 5 & Campo 6 & Campo 7 & Campo 5 & Campo 6 & Campo 7 \\
\hline $\mathrm{V}_{3}$ & $6,30 \pm 1,06$ & $50,25 \pm 4,92$ & $62,62 \pm 4,11$ & $0,68 \pm 0,11$ & $6,99 \pm 0,66$ & $8,30 \pm 0,50$ \\
$\mathrm{~V}_{4}$ & $3,24 \pm 0,53$ & $23,25 \pm 2,23$ & $35,33 \pm 2,11$ & $0,54 \pm 0,09$ & $4,11 \pm 0,37$ & $4,11 \pm 0,21$ \\
$\mathrm{R}_{5}$ & $2,80 \pm 0,37$ & $8,72 \pm 0,56$ & $\mathbf{8 , 9 8} \pm 0,41$ & $0,59 \pm 0,08$ & $1,77 \pm 0,13$ & $1,79 \pm 0,07$ \\
$\mathrm{R}_{6}$ & $5,24 \pm 0,27$ & $6,17 \pm 0,30$ & $5,19 \pm 0,17$ & $1,10 \pm 0,07$ & $1,57 \pm 0,11$ & $1,53 \pm 0,06$ \\
$\mathrm{R}_{7}$ & $5,48 \pm 0,32$ & $5,50 \pm 0,20$ & $4,47 \pm 0,13$ & $1,24 \pm 0,08$ & $1,56 \pm 0,11$ & $1,96 \pm 0,08$ \\
$\mathrm{R}_{8}$ & $5,48 \pm 0,32$ & $5,49 \pm 0,15$ & $4,54 \pm 0,12$ & $1,01 \pm 0,07$ & $1,41 \pm 0,09$ & $2,19 \pm 0,09$ \\
$\mathrm{R}_{9}$ & $7,13 \pm 0,55$ & $12,25 \pm 1,23$ & $8,70 \pm 0,54$ & $1,31 \pm 0,10$ & $2,28 \pm 0,17$ & $2,09 \pm 0.09$ \\
\hline GS = Estádios de crescimento: $\mathrm{V}_{3}=$ primeira folha trifoliolada; $\mathrm{V}_{4}=$ terceira folha trifoliolada; $\mathrm{R}_{\mathrm{s}}=$ pré florescimento; $\mathrm{R}_{6}=$ \\
Florescimento; $\mathrm{R}_{7}=$ formação das vagens; $\mathrm{R}_{8}=$ enchimento das vagens e $\mathrm{R}_{9}=$ maturidade fisiológica
\end{tabular}



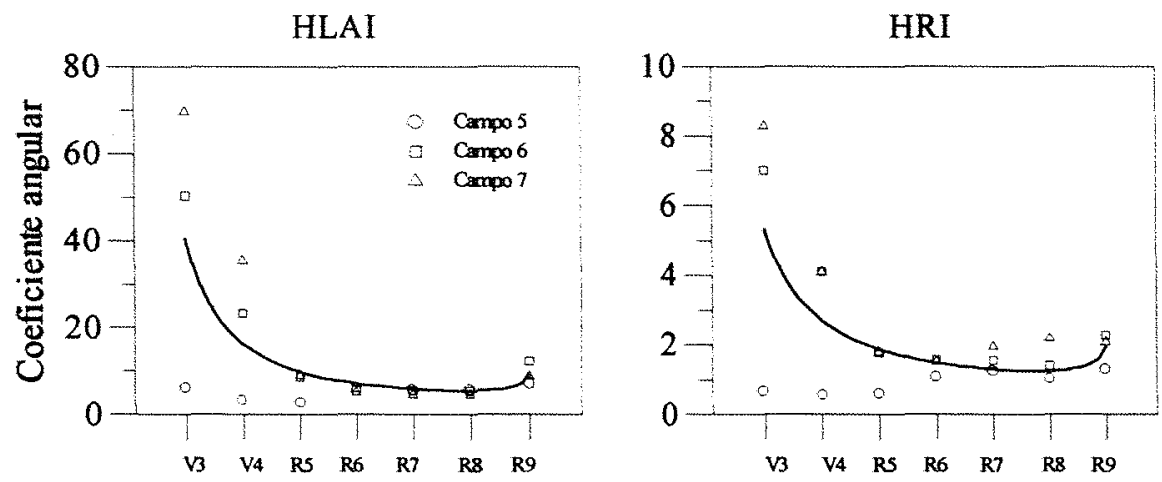

Figura 4 - Coeficientes angulares obtidos pela regressão linear, com passagem forçada pela origem, de produção $\left(\mathrm{g}\right.$ planta $\left.^{-1}\right)$ com índice de área foliar sadia (HLAI), e radiação interceptada pela área foliar sadia por unidade de tempo (HRI, MJ $\mathrm{m}^{-2}$ ), medidos nos estádios de crescimento de feijoeiros infectados com antracnose, em três experimentos conduzidos em Pereiras, SP, 1997. As linhas representam a função beta ajustada aos dados. Para maiores detalhes veja texto. Estádios de crescimento: $V_{3}=$ primeira folha trifoliolada; $V_{4}=$ terceira folha trifoliolada; $R_{5}=$ pré florescimento; $R_{6}=$ florescimento; $R_{7}=$ formação das vagens; $R_{8}=$ enchimento das vagens e $R_{9}=$ maturidade fisiológica. 

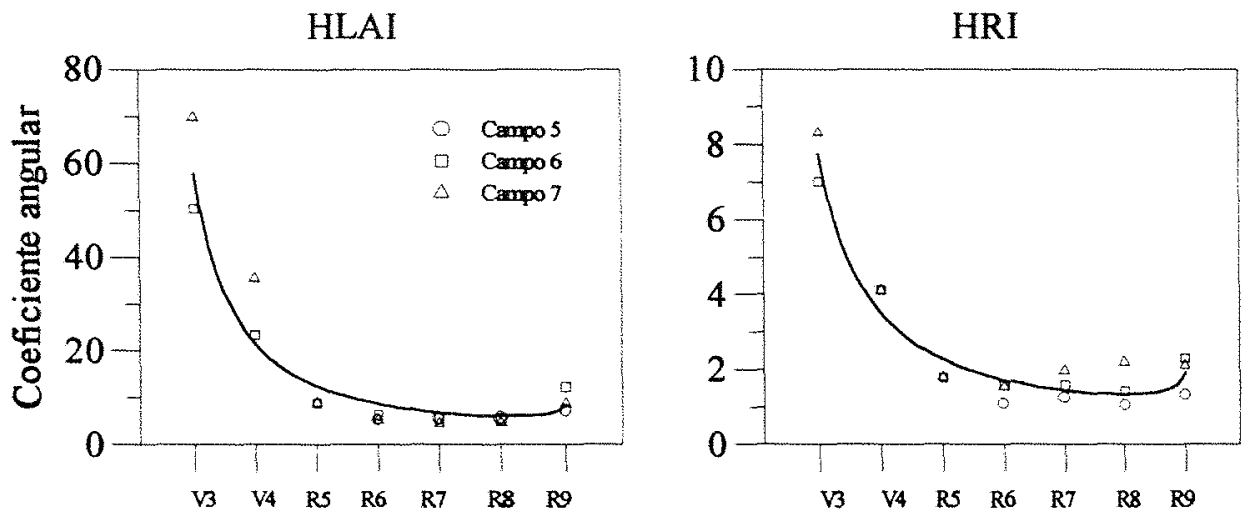

Figura 5 - Coeficientes angulares obtidos pela regressão linear, com passagem forçada pela origem, de produção ( $\left(\right.$ planta $\left.^{-1}\right)$ com índice de área foliar sadia (HLAI), e radiação interceptada pela área foliar sadia por unidade de tempo (HRI, MJ $\mathrm{m}^{-2}$ ), medidos nos estádios de crescimento de feijoeiros infectados com antracnose, em três experimentos conduzidos em Pereiras, SP, 1997. No campo 5 foram considerados apenas os estádios $R_{6}-R_{9}$. Para maiores detalhes veja texto. Estádios de crescimento: $V_{3}=$ primeira folha trifoliolada; $V_{4}=$ terceira folha trifoliolada; $R_{5}=$ pré florescimento; $R_{6}=$ florescimento; $R_{7}=$ formação das vagens; $R_{8}=$ enchimento das vagens e $R_{9}=$ maturidade fisiológica. 
Seguindo o exemplo relatado por Rotem et al. (1983a) para o patossistema batata/Phytophthora infestans, diferentes sistemas de produção resultam em diferentes relações entre produção e HAD. Este resultado está de acordo com os encontrados neste ensaio, no qual o ajuste das relações em uma única equação:

Produção $=-5,6+0,14 \mathrm{HAD}$ com melhor $\mathrm{R}^{2}=82,0 \%$, foi realizado, embora existissem diferenças entre as relações de cada experimento. Segundo os mesmos autores, para a relação produção com HAA, diferentes sistemas de produção não resultam em diferentes relações com produção. Este resultado não foi verificado neste trabalho onde também foi ajustada uma única equação para as relações obtidas nos experimentos: Produção $=-16,96+0,05 \mathrm{HAA}$ com melhor $\mathrm{R}^{2}=67,4 \%$, embora existissem diferenças entre as relações. Resultados similares foram encontrados por Bergamin Filho et al. (1997). Isto pode indicar falta de transportabilidade aos modelos e reforçam a idéia da parcela controle sensu Lopes et al. (1994).

A relação entre produção e HAA, não é sempre linear como considerada por muitos autores (Monteith, 1977; Waggoner \& Berger, 1987; Gaunt, 1995; Madden \& Nutter Jr., 1995). Sabe-se que a forma desta relação depende de vários fatores, especialmente HLAI, coeficiente de extinção da cultura e seu hábito de crescimento. Tomando-se como exemplo o campo 6, onde o HLAI aos 82 dias após o plantio foi de $3,47 \pm 0,05$, a relação foi mais exponencial do que linear $\left(R^{2}=75,8\right.$ e $R^{2}=51,04 \%$, respectivamente). Segundo Bergamin Filho et al. (1997), maiores HLAI são responsáveis pela relação exponencial. Entretanto, neste trabalho, os maiores valores de HLAI, 5,35 $\pm 0,06$ foram encontrados para o campo 7. Nesse experimento, a relação linear mostrou-se superior à exponencial $\left(\mathrm{R}^{2}\right.$ de 27,4 e $27 \%$ respectivamente). Resultados semelhantes foram obtidos por Canteri (1998). O crescimento exponencial poderia ocorrer para a relação produção e HAA para amendoim cultivar 'Florunner', descrita como linear por Waggoner \& Berger (1987), caso estes autores tivessem utilizado $K=0,9$ ou 0,74 ao invés de $K=0,412$ (Bergamin Filho et al., 1997), demonstrando deste modo a influência do valor de $K$ no modelo da relação obtida. 
Embora se tenha encontrado relação entre produção e AUDPC, os resultados dos três experimentos demonstram superioridade da metodologia baseada em HAD e HAA em relação à severidade de doença (AUDPC), não importando a consideração ou não de desfolha do hospedeiro (Tabela 2 e Tabela 3), para a quantificação de danos no patossistema feijão/antracnose. Em estudos recentes, mesmo patossistemas com forte relação entre severidade de doença e produção, a metodologia baseada em HAD e HAA tem fornecido melhores resultados (Aquino et al., 1992; Ferrandino \& Elmer, 1992; Nutter Jr. \& Littrell, 1996). Em adição, a metodologia baseada em HAD e HAA é tida por muitos autores (Kranz \& Jörg, 1989; Gaunt, 1995) como ideal, ou a única capaz de produzir interpretações reproduziveis de danos a culturas, induzidas por um complexo de múltiplas doenças ou pragas.

Para tomada de decisão, variáveis integrais, como HAD ou HAA não são apropriadas (Madden \& Nutter Jr., 1995). Seria melhor desenvolver vários modelos empíricos de ponto crítico, usando HLAI ou HRI para se estimar a produção em várias épocas durante a estação de crescimento, do que integrar estas variáveis para se obter HAD ou HAA. Esses resultados, apresentados na Tabela 4 e Figura 4, são promissores. Os coeficientes angulares da relação entre produção e HRI tendem a estabilizar-se $1,477 \pm 0,07 \mathrm{~g} \mathrm{Mr}^{1}$, independentemente da época de plantio ou estádio de crescimento de $R_{5}$ a $R_{8}$. Essa estabilização contrasta com o nível de dano, originalmente, baseado na população de pragas ou patógenos (Stern et al., 1959). Deste modo, HRI parece incorporar características ideais para se tornar uma variável explanatória, imprescindível, para implementação de um sistema de manejo de doenças. Esse sistema pode ser usado para produzir recomendações precisas a nivel de campo. Para isto, Lopes et al.(1994) propuseram, para cada situação de produção, a adoção de uma parcela controle livre de doença. Cada situação de produção deve ser o mais homogênea possível, no que se refere a fatores que influenciam a produção, como tipo de solo, microclima, práticas culturais e cultivar. Baseando-se na relação produção e HRI, e usando de informações sobre a eficiência de medidas de controle e nos custos 
envolvidos, um novo e conceitual nível de dano pode ser determinado. Esse nível, não é mais expresso em insetos por planta ou severidade de doença, ambos de relação incerta com produção (Waggoner \& Berger, 1987), mas em unidades de HRI (MJ m²). Deste modo, medidas de controle somente seriam recomendadas quando a diferença entre HRI da parcela controle e HRI da cultura for igual ou maior que o nível de dano (Lopes et al., 1994).

Devido à inexistência de dados sobre o efeito de medidas de controle sobre HRI para a antracnose do feijoeiro, um cálculo aproximado do grau de sensibilidade com o qual HRI deve ser determinado para tomada de decisão. Usando-se do mesmo raciocínio de Bergamin Filho et al. (1997), tem-se que a estabilização do coeficiente angular das regressões entre produção e HRI, entre os estádios de crescimento $\mathrm{R}_{5}$ a $\mathrm{R}_{8}$, ao redor de $1,48 \mathrm{~g} \mathrm{MJ}^{-1}$, significa que cada unidade de HRI representa um incremento de produção de $1,48 \mathrm{~g}_{\text {planta }}{ }^{-1}$, ou $350 \mathrm{~kg} \mathrm{ha}^{-1}$, considerandose 240000 planta ha ${ }^{-1}$. Assim, se for considerado o custo de controle de Colletotrichum lindemuthianum como $\$ 40 \mathrm{ha}^{-1}$ (equivalente a aproximadamente $96 \mathrm{~kg}$ de feijão) podese estimar o limiar de dano econômico (LDE) em 96/350 =0,27, ou aproximadamente $1 / 4$ de uma unidade de HRI. Para o patossistema feijão/mancha angular, o LDE foi estimado em 1/3 de HRI (Bergamin Filho et al., 1997). Essa diferença entre os LDE deixa de existir caso neste trabalho fosse considerado a mesma densidade de plantio utilizada por Bergamin Filho et al. (1997), que foi de 200.000 plantas/ha. Com essa população, a produtividade deste ensaio seria de $296 \mathrm{~kg} / \mathrm{ha}$, e o limiar de dano econômico passaria a ser $1 / 3$ de $\operatorname{HRI}(96 / 296=0,32)$. Por outro lado, com a densidade de plantio utilizada percebe-se que uma maior sensibilidade para determinação do LDE é necessária para a antracnose. Isto permite inferir que tal doença causa maiores danos ao feijoeiro do que a mancha angular. Tais resultados parecem coerentes, uma vez que a queima foliar que pode ser ocasionada pela antracnose a nível de campo é muito mais severa do que a desfolha promovida pela mancha angular.

Essa estimativa aproximada do limiar de dano econômico (LDE), igual a 1/4 de HRI, significa que a diferença entre a parcela controle e a situação de produção 
não poderia atingir 1/4 de uma unidade de HRI. Bergamin Filho et al. (1997) estimaram também o LDE em função da HLAI, que é a variável efetivamente quantificada no campo e encontraram os valores $1 / 20$ de HLAI quando o HLAI no campo for igual a 0,$2 ; 1 / 10$ para 1,$2 ; 1 / 5$ para 2,$2 ; 1 / 3$ para 2,$9 ; 1 / 2,5$ para 3,$2 ; 1 / 2$ para 3,5 e $1 / 1$ para 4,5 . Resultados similares podem ser obtidos utilizando-se HLAI ao invés de HRI (Tabela 4 e Figura 4). Comparado com HRI, HLAI tem a desvantagem de ser influenciado pela situação de produção.

Para satisfazer os requerimentos para tomada de decisão baseada na metodologia de HLAI e HRI, novos desafios são lançados a pesquisadores para acompanhamento da cultura durante a estação de crescimento. Este acompanhamento inclui a determinação da proporção de área foliar afetada pela doença, o que pode ser facilitada por escalas diagramáticas, e a área foliar, para estimativa de LAI. Para acompanhamento da área foliar, escalas diagramáticas para tamanhos de folhas ou de plantas inteiras, são ferramentas úteis; entretanto, não apresentam a acurácia necessária para permitir uma tomada de decisão (Bergamin Filho et al., 1997). A determinação da maior largura do folíolo central das folhas de cada planta marcada, obtida neste trabalho, tem a requerida acurácia e apresenta a vantagem de ser barata e não destrutiva. Entretanto, essa metodologia envolve uma tremenda quantidade de trabalho de campo, o que torna sua implementação em larga escala inviável. Recentemente, vários aparelhos eletrônicos, dentre eles, o radiômetro de múltiplo espectro, têm sido testados para estimativa de área foliar e de LAI, com resultados promissores (Canteri et al., 1998). 


\section{ANTRACNOSE DO FEIJOEIRO: RELAÇÃO ENTRE SEVERIDADE, DESFOLHA, ÁREA FOLIAR E MEDIDAS DE REFLETÂNCIA}

\subsection{RESUMO}

Medidas de refletância são mais fáceis e rápidas de ser obtidas do que avaliações de severidade de doença ou área foliar, podendo viabilizar a implementação de um sistema de manejo da antracnose (Colletotrichum lindemuthianum) do feijoeiro. Para tanto, foram conduzidos três experimentos em feijoeiro, cultivar Carioca, para se investigarem possiveis relações entre severidade de antracnose, desfolha, variáveis derivadas da área foliar, produção e medidas de refletância. As leituras de refletância foram feitas em 8 comprimentos de onda, de $460 \mathrm{~nm}$ a $810 \mathrm{~nm}$ em intervalos de $50 \mathrm{~nm}$. As refletâncias da copa em infravermelho (IR), $810 \mathrm{~nm}\left(\mathrm{R}_{810}\right)$ e vermelho $(\mathrm{R}), 660 \mathrm{~nm}$ $\left(R_{660}\right)$ e $610 \mathrm{~nm}\left(R_{610}\right)$, foram usadas para calcular o índice vegetativo (IR/R), e diferença normalizada (ND). Desfolha e severidade de antracnose apresentaram baixas relações lineares com medidas de refletância. Os melhores resultados foram com refletância em $710 \mathrm{~nm}$, obtidos somente sob condições de alta percentagem de desfolha e altas severidades de doença. As curvas de refletância em $810 \mathrm{~nm}$ para todos os tratamentos e épocas de plantio, apresentaram formato bem semelhante à curva do índice de área foliar (LAI). As melhores relações lineares com LAI, índice de área foliar sadia (HLAI) e absorção de área foliar sadia por unidade de tempo (HRI), foram obtidas com a refletância em 760 e $810 \mathrm{~nm}$, e para $\mathrm{ND}_{810,660}$. Apresentou-se um modelo 
para estimar a HLAI em função da $R_{\mathbf{8 1 0}}$. As medidas de duração da área foliar sadia $\mathrm{e}$ absorção de área foliar sadia correlacionaram-se bem com a produção, indicando o potencial desse tipo de medida para relações com danos e uso no manejo de doenças em feijoeiro.

\subsection{INTRODUÇÃO}

A antracnose do feijoeiro (Phaseolus vulgaris L.), causada por Colletotrichum lindemuthianum (Sacc. \& Magnus) Br. \& Cav., é uma das doenças predominantes em todo mundo (Schwartz, 1994). Esta doença é uma das mais importantes, afetando as cultivares suscetíveis estabelecidas em localidades com temperaturas moderadas a baixas e alta umidade relativa (Rava et al., 1998). O patógeno causa lesões nas folhas, pecíolos, caules e vagens, podendo causar severa desfolha quando ocorre a completa necrose foliar. Os danos ocasionados pela doença podem ser de até $100 \%$, quando são semeadas sementes infectadas e as condições de ambiente são favoráveis (Rava et al., 1998; Sartorato, 1988).

Em qualquer sistema de manejo de doenças, a quantificação de danos provocados por patógenos é um dos componentes essenciais. Geralmente, para se quantificar e estimar danos são utilizadas avaliações visuais de severidade da doença. Entretanto, uma nova abordagem apresentada por Waggoner \& Berger (1987) relaciona os danos à quantidade de área foliar sadia remanescente na cultura. Segundo essa metodologia, a produção de uma cultura está intimamente relacionada com a porção de radiação que as plantas conseguem capturar. Esta radiação é função da duração de área foliar ( $\mathrm{HAD}$, dias) e da absorção de área foliar (HAA, $\mathrm{MJ} \mathrm{m}^{-2}$ ), variáveis estas dependentes do índice de área foliar (LAI) observado durante o ciclo da cultura (Bergamin Filho et al., 1995). Desta forma, quando se pretende estimar o dano provocado por uma determinada doença, pode-se avaliar a alteração que ela provoca na 
área foliar do hospedeiro ao invés de avaliar somente a quantidade de área com sintomas, a qual está relacionada indiretamente à produção (Lopes et al., 1994).

Medições de duração da área foliar sadia (HAD) e absorção da área foliar sadia (HAA), têm mostrado maior eficiência na determinação de danos provocados por doenças do que a severidade de doença. Isto já foi verificado para vários patossistemas do feijoeiro (Nunes \& Bergamin Filho, 1996; Carneiro, 1995; Iamauti, 1995; Godoy, 1995; Canteri et al., 1998). Estes métodos são muito mais trabalhosos do que as medições de intensidade de doença, e muitas vezes, inviáveis de serem executados sem se destruir a amostra (Bergamin Filho \& Amorim, 1996; Canteri \& Giglioti, 1996). Enquanto para a primeira há necessidade de se conhecer a área foliar das plantas, geralmente, medindo-se folha a folha, na segunda podem-se utilizar escalas diagramáticas para fazer estimativas (Bergamin Filho \& Amorim, 1996).

Para viabilizar o uso de HAD e HAA no cálculo de danos, técnicas de sensoriamento remoto têm demonstrado potencial para execução de estimativas rápidas e precisas do índice de área foliar, principalmente sob condições de campo (Asrar et al., 1984; Nilsson, 1995; Nutter Jr. \& Littrell, 1996, Canteri et al., 1998).

Sensoriamento remoto envolve métodos de mensuração de propriedades de um objeto sem contato físico entre o instrumento de medida e o objeto. Estas medidas não destroem e não alteram as propriedades do objeto e este pode ser analisado muitas vezes sem ser danificado. Medidas de refletância são o principal exemplo do sensoriamento remoto aplicado à fitopatologia (Nilsson, 1995).

Propriedades específicas da vegetação, em condições de sanidade ou doença, influenciam a quantidade e qualidade da radiação emitida e refletida pela copa das plantas (Nilsson, 1995). Medições radiométricas de vegetação possuem como característica uma mudança drástica na refletância entre 680 e $750 \mathrm{~nm}$. Esta característica é única para vegetação verde e permite avaliações de comportamento da clorofila e do índice de área foliar, independentemente de variações na cobertura do solo e são particularmente úteis para detecção precoce de estresse na vegetação (Nilsson, 1995), entre os quais as doenças se encontram incluídas. 
Índices de vegetação auxiliam no uso das informações contidas na refletância dos vários comprimentos de onda. Algumas vezes é suficiente analisar o decréscimo da refletância na faixa do infravermelho. Entretanto, melhores informações podem ser obtidas se forem combinados dados de várias faixas do espectro. $O$ índice de vegetação (infravermelho/vermelho) é relacionado com mudanças no índice de área foliar (LAI), enquanto a diferença normalizada ((infravermelho - vermelho) / (infravermelho + vermelho)) é mais apropriada para relações com a interceptação de radiação fotossinteticamente ativa (Hatfield, 1990).

Nutter Jr. \& Cunfer (1988) e Nutter Jr. (1989) determinaram uma estreita correlação entre a refletância da copa em $800 \mathrm{~nm}$ e a área foliar sadia, nos patossistemas cevada-Rhynchosporium secalis e amendoim-Cercosporidium personatum-Puccinia arachidis, respectivamente. Aquino et al. (1992) encontraram excelente relação entre a percentagem de radiação refletida e a área foliar sadia de amendoim atacado por C. personatum, com $\mathrm{R}^{2}$ de até $95,0 \%$. A rapidez e facilidade de execução desse método foram demonstradas por Nutter Jr. et al. (1990). Os autores demonstraram que o tempo gasto para avaliações com radiômetro ocupou menos de $3 \%$ do tempo necessário para avaliações de severidade com escalas diagramáticas, no patossistema amendoim- $C$. personatum. Canteri (1998), trabalhando a nível de campo, com o patossistema feijão/Phaeoisariopsis griseola, não encontrou um comprimento de onda que pudesse ser usado para estimar apenas a severidade de doença. Por outro lado, os índices de área foliar (LAI) obtidos para as cultivares Carioca e Iapar 44, em duas épocas de plantio e sob dois tratamentos de controle da mancha angular, relacionaramse bem com refletância a $810 \mathrm{~nm}\left(\mathrm{R}_{810}\right)$. Para o índice de área foliar sadia (HLAI), boas correlações foram obtidas com refletância em $810 \mathrm{~nm}\left(\mathrm{R}^{2}=84,7 \%\right)$ e com a diferença normalizada, usando-se 810 e $660 \mathrm{~nm}\left(\mathrm{ND}_{810,660}\right)\left(\mathrm{R}^{2}=86,6 \%\right)$. Para absorção de área foliar sadia por unidade de tempo (HRI), encontrou-se melhor relação com a $\mathrm{ND}_{810,610}$ $\left(\mathrm{R}_{2}=82,6 \%\right)$.

O objetivo deste trabalho foi verificar se medidas de refletância, em vários comprimentos de onda, ou suas combinações, apresentam relação com a 
severidade de antracnose do feijoeiro, desfolha, índice de área foliar sadio (HLAI), absorção da área foliar sadia por unidade de tempo (HRI), duração de área foliar sadia (HAD), absorção de área foliar sadia (HAA) e produção. Secundariamente, procurou-se propor um modelo para estimativa de HLAI, para subsidiar a implementação de um sistema de manejo de doença do feijoeiro.

\subsection{MATERIAL E MÉTODOS}

\subsubsection{Experimentos de campo}

Foram conduzidos três experimentos durante o ano de 1997, com a cultivar 'Carioca'. Esses ensaios foram conduzidos na Estação Experimental Nova Fazenda Hokko, situada na Rodovia SP 143, Km 8,5, município de Pereiras, SP $\left(23^{\circ} \mathrm{S}\right.$, $60^{\circ} \mathrm{W}$, altitude de $479 \mathrm{~m}$ ). O primeiro experimento foi semeado em 17 de abril de 1997 , e foi denominado de campo 5 . Os demais foram plantados 30 e 60 dias após o plantio do primeiro, e foram denominados de campo 6 e campo 7, respectivamente.

Em todos os ensaios, utilizou-se do mesmo delineamento experimental, de blocos ao acaso, com cinco tratamentos e três repetições. Cada parcela de $12 \mathrm{~m}^{2}$ possuia quatro linhas de plantio, com seis metros de extensão. $O$ espaçamento entre linhas foi de $0,5 \mathrm{~m}$, procurando-se obter uma densidade de 12 plantas por metro linear. A manutenção dos experimentos deu-se por meio de práticas culturais convencionais, utilizadas em campos comerciais, incluindo plantio, adubações, irrigações, quando necessários, e pulverizações com os inseticidas metamidofós e cartap. Estas pulverizações objetivaram deixar os experimentos livres da interferência de pragas e de ferrugem.

Quando os plantios atingiram o estádio $V_{3} / V_{4}$ (Michaels, 1994), procedeu-se à inoculação de todas as parcelas. Para tanto, utilizou-se de isolados de 
Colletotrichum lindemuthianum, obtidos junto ao Instituto Agronômico do Paraná e a Universidade Federal de Lavras. Esses isolados foram multiplicados em meio de ágarvagem (Benhamon et al., 1991), mantidos por 14 dias sob escuro constante e temperatura de $21{ }^{\circ} \mathrm{C}$. Decorrido esse período, obteve-se uma suspensão de esporos, padronizada em $10^{6}$ esporos $/ \mathrm{ml}$. Esta suspensão foi pulverizada sobre as plantas, utilizando-se pulverizador costal de pressão constante, $40 \mathrm{Lb} / \mathrm{pol}^{2}$, aplicando-se $130 \mathrm{ml}$ da suspensão nas duas fileiras centrais de cada parcela. A inoculação foi realizada sempre após as 20:00 h, sendo previamente aspergida água destilada sobre as plantas, do mesmo modo utilizado para a inoculação. Esse procedimento objetivou proporcionar molhamento foliar até que fosse atingido o ponto de orvalho $\mathrm{e}$ conseqüentemente ocorresse molhamento foliar natural. Isto se deu em função da impossibilidade de colocar câmara úmida em todo o ensaio.

Para estabelecer diferentes severidades de doença entre as parcelas, realizaram-se pulverizações com fungicida à base de trifenil acetato de estanho, em dosagem de $0,2 \mathrm{~kg} / \mathrm{ha}$, em diferentes épocas. No tratamento 1 as pulverizações foram iniciadas uma semana após a inoculação e de freqüência semanal, sendo considerado como parcela controle sensu Lopes et al. (1994). No tratamento 2 a primeira pulverização foi feita no estádio $R_{5}$ (Michaels, 1994), e repetida uma única vez após 14 dias. No tratamento 3 realizou-se pulverização no estádio $R_{5}$ (Michaels, 1994). No tratamento 4 a pulverização foi realizada 14 dias após ter sido atingido o estádio $R_{5}$ (Michaels, 1994). No tratamento 5, testemunha, não se realizou controle da antracnose do feijoeiro.

\subsubsection{Crescimento do hospedeiro, severidade de doença e produção}

Crescimento do hospedeiro, severidade de doença e produção foram avaliados nas duas fileiras centrais de cada parcela. As parcelas foram divididas ao meio, sendo na metade inicial realizadas as leituras de refletância, para evitar 
interferência da movimentação das plantas, nas avaliações. $\mathrm{Na}$ outra metade, foram marcadas 4 plantas com fita plástica colorida no estádio $V_{3} / V_{4}$ (Michaels, 1994). Procurou-se selecionar plantas com tamanho e vigor semelhantes. Nessas plantas marcaram-se todas as folhas, que foram surgindo, com o auxilio de uma etiqueta de papel numerada, embebida em parafina. As folhas foram numeradas objetivando-se quantificar a desfolha promovida pelo patógeno.

A área foliar (LA, $\left.\mathrm{cm}^{2}\right)$ de todas as folhas de cada planta marcada foi estimada semanalmente, iniciando-se no estádio $V_{3} / V_{4}$ (Michaels, 1994). Para isto, a maior largura do folíolo central de cada folha $(L, \mathrm{~cm})$ foi medida com o auxilio de uma régua. A área foliar foi estimada a partir da relação empírica (Bassanezi, 1995):

$$
\mathrm{LA}=3,03 L^{1,87}, \mathrm{R}^{2}=88 \% \text {. }
$$

A avaliação da severidade da antracnose do feijoeiro foi realizada simultaneamente com à avaliação de área foliar com auxilio de uma escala diagramática de severidade (Godoy et al., 1997), com a qual a percentagem média de severidade para os três foliolos de todas as folhas das plantas marcadas foi avaliada.

A desfolha do hospedeiro foi quantificada entre avaliações consecutivas. Para tanto, quando folíolos ou folhas atingiam $100 \%$ de necrose, ou apresentavam-se caídos em função do patógeno, suas respectivas áreas foliares foram consideradas como desfolha. Esses dados foram computados para obtenção da área foliar total das plantas. Em seguida, os dados de desfolha foram utilizados para cálculo da percentagem de desfolha (DF, \%) tomando-se como referência a área foliar total das plantas:

$$
\mathrm{DF}=(\text { Área desfolhada } / \text { Área foliar total }) * 100
$$

A produção foi determinada colhendo-se as duas linhas centrais de cada parcela, em uma área de $6,0 \mathrm{~m}^{2}$. Mediu-se a umidade dos grãos e padronizaram-se os resultados para $12 \%$ de umidade. Optou-se por trabalhar com a produção da parcela, método da parcela experimental, ao invés da produção por planta, método da planta individual, (Bergamin Filho \& Amorim, 1996) para que fosse possivel estabelecer relações dessa variável com medidas de refletância. 


\subsubsection{Variáveis integrais}

A AUDPC para cada planta marcada foi calculada por integração trapezoidal:

$$
\mathrm{AUDPC}=\sum_{i=1}^{n-1}\left[\left(X_{i}+X_{i+1}\right) / 2\right]\left(t_{i+1}-t_{i}\right)
$$

Em que $X$ é a severidade média da doença (porcentagem), $X_{\mathrm{i}}$ é a severidade no tempo $t_{i}$; $n$ é o número de avaliações e $\left(t_{i+1}-t_{i}\right)$ é o intervalo entre duas avaliações consecutivas. O cálculo da AUDPC foi realizado, quando se considerou a desfolha promovida pelo patógeno para estimativa de $X$.

Os valores de índice de área foliar (LAI) de cada parcela foi obtido multiplicando-se a média dos LAI das 4 plantas marcadas das parcelas, pela densidade de plantas por $\mathrm{m}^{2}$ (24). A duração de área foliar sadia (HAD) foi calculada pela fórmula:

$$
\mathrm{HAD}=\sum_{i=1}^{n-1}\left\{\left[L A I_{i}\left(1-X_{i}\right)+L A I_{i+1}\left(1-X_{i+1}\right)\right] / 2\right\}\left(t_{i+1}-t_{i}\right)
$$

onde $\mathrm{LAI}_{\mathrm{i}}$ é o índice de área foliar no tempo $t_{i}$. $\mathrm{O}$ valor do índice de área foliar sadio (HLAI) para cada data de avaliação foi calculado como HLAI = LAI $(1-X)$.

Os valores de radiação interceptada $\left(\mathrm{RI}_{\mathrm{i}}\right) \mathrm{em} \mathrm{MJ} \mathrm{m}^{-2}$ foram calculados como:

$$
\mathrm{RI}_{i}=I_{i}\left[1-\exp \left(-k \mathrm{LAI}_{i}\right)\right]
$$

em que $I_{i}$ é a média de radiação solar incidente $\left(\mathrm{MJ} \mathrm{m}^{-2}\right)$ no período $\left(t_{i+1}-t_{i}\right)$ e $k$ é o coeficiente de extinção; usou-se $k=0,7$ (Miglioranza, 1992; Bergamin Filho et al., 1997). O valor da absorção da área foliar sadia (HAA) em $\mathrm{MJ} \mathrm{m}^{-2}$ foi calculado como:

$$
\mathrm{HAA}=\sum_{i=1}^{n-1} I_{i}\left(\left\{\left(1-X_{i}\right)\left[1-\exp \left(-k L A I_{i}\right)\right]+\left(1-X_{i+1}\right)\left[1-\exp \left(-k L A I_{i+1}\right)\right]\right\} / 2\right)\left(t_{i+1}-t_{i}\right)
$$


Os valores de HRI (MJ m${ }^{-2}$ ), para cada data de avaliação, foram calculados pela fórmula $H R I=R I(1-X)$. A radiação solar incidente $(I)$ foi medida por uma estação meteorológica computadorizada situada a $500 \mathrm{~m}$ da área experimental.

\subsubsection{Medidas de refletância}

As leituras de refletância foram feitas no mesmo dia em que se realizaram as avaliações de área foliar. Para tanto, utilizou-se um radiômetro de múltiplo espectro portátil CropScan, modelo MSR87, que armazenou a percentagem de luz refletida pela copa em oito comprimentos de onda $(460,510,560,610,660,710$, 760 e $810 \mathrm{~nm}$ ). O sensor foi montado em uma barra e um armazenador de dados ("data logger"), conectado ao sensor; automaticamente gravou os dados de todos os canais. Durante a leitura a barra permanecia em um ângulo de $45^{\circ}$, com o sensor a uma altura de 2,0 $\mathrm{m}$ sobre o solo. Foram feitas 4 leituras por parcela, sendo que a área medida foi um círculo com um diâmetro igual a metade da altura do sensor, centralizado no intervalo entre as duas linhas centrais de cada parcela. Todas as medidas de refletância foram feitas entre 11:00 e 12:00 h.

As medidas de refletância foram usadas para calcular o índice vegetativo, IR/R, e a diferença normalizada, $N D$, onde $N D=(I R-R) /(I R+R)$ (Nilsson, 1995). Usaram-se três combinações para os comprimentos de onda infravermelho (IR) e vermelho (R). Para o IR usaram-se sempre 810 nanômetros $(\mathrm{nm})$ e para o $R$ usaramse 610,660 e $710 \mathrm{~nm}$, resultando nas combinações $I R / R_{610}, I R / R_{660}, I R / R_{710}, N_{810,610}$, $\mathrm{ND}_{810,660}$ e ND 810,710 .

Para cada comprimento de onda e para os índices vegetativos, foram calculados por integração trapezoidal os valores da área sob a curva das medidas de refletância (AUR) para cada parcela, pela fórmula:

$$
\mathrm{AUR}=\sum_{i=1}^{n-1}\left[\left(R_{i}+R_{i+1}\right) / 2\right]\left(t_{i+1}-t_{i}\right)
$$


Em que $R$ é a medida de refletância em cada comprimento de onda (porcentagem), $R_{\mathrm{i}}$ é a medida de refletância no tempo $t_{i} ; n$ é o número de avaliações e $\left(t_{i+l}-t_{i}\right)$ é o intervalo entre duas avaliações consecutivas.

\subsubsection{Análise dos dados}

As relações de produção, LAI, HLAI, HRI, HAD, HAA, severidade de doença e medidas de refletância foram obtidas por regressão linear usando-se o programa STATISTICA (StatSoft, Tulsa, OK). Os testes de média foram realizados com o auxilio do programa PlotIT for Windows (Scientific Programming Enterprises, Haslsett, MI).

\subsection{RESULTADOS E DISCUSSÃO}

4.4.1 Comportamento do índice de área foliar, severidade de antracnose e refletância durante o ciclo da cultura

Durante o ciclo da cultura, observou-se o comportamento do índice de área foliar (LAI), da severidade da antracnose e da refletância em infravermelho na faixa de $810 \mathrm{~nm}\left(\mathrm{R}_{810}\right)$, em ambos os ensaios, e para os cinco tratamentos (Figura 6). Os tratamentos apresentados na Figura 6 representam a parcela controle, com aplicação semanal do fungicida (círculos cheios) e a testemunha (círculos vazios). Os demais tratamentos apresentaram curvas bastante semelhantes às obtidas pelo tratamento testemunha e portanto, não foram apresentados. Os primeiros sintomas da antracnose foram observados aos 48 dias após o plantio (DAP) no campo 5, aos 54 DAP no campo 
6 e aos 51 DAP no campo 7. Em todos os plantios, a doença apresentou severidade bastante considerável nas parcelas sem controle (até 95,4\%), o que provocou grande variação na quantidade de doença entre as parcelas com e sem tratamento. Isto permitiu avaliar o comportamento das medidas de refletância em situações de muita e pouca doença. Entretanto, durante a condução do campo 7, não foi possivel a realização de leituras com o radiômetro durante todo o ciclo da cultura, e por esta razão representouse na Figura 6 apenas a fase inicial das curvas de progresso de doença, LAI e refletância.

O comportamento do índice de área foliar (LAI) foi semelhante para os três plantios. Os tratamentos com controle da doença apresentaram um LAI máximo maior que os tratamentos sem controle. Para o campo 7 tal comportamento não foi tão evidente, sendo as duas curvas muito semelhantes. Isto pode ser explicado pela reduzida severidade observada, quando comparada à obtida nos demais experimentos. A diferença entre LAI, das parcelas com e sem controle, ficou evidente a partir dos $48 \mathrm{e}$ 54 DAP para o campo 5 e 6 respectivamente. A data em que a diferença ficou perceptível coincidiu com o aumento da severidade da antracnose. A severidade média nessas datas, nas parcelas sem tratamento, era 4,6 e 3,7\%, enquanto nas parcelas tratadas era 3,9 e 0,1\%, para os campos 5 e 6, respectivamente. Apesar de não estar representado graficamente, o índice de área foliar sadio (HLAI) apresentou comportamento muito semelhante ao LAI, principalmente nas fases iniciais do ciclo, quando a severidade da doença era baixa. A diferença de $\mathrm{HLAI}$ entre os tratamentos poderia ter sido provocada pelo aumento da área foliar doente ou pela redução do crescimento das plantas nas parcelas sem tratamento.

A curva da refletância em $810 \mathrm{~nm}$ apresentou um formato bem semelhante à curva do LAI, inclusive para o momento em que as diferenças entre as parcelas tratadas e não tratadas tornaram-se perceptíveis. A refletância na faixa do infravermelho, segundo Hatfield (1990), é um ótimo indicativo do índice de área foliar das culturas. Observações das mudanças nos valores da refletância durante a estação de cultivo, feitas pelo mesmo autor, demonstraram um incremento com o desenvolvimento 
da copa e uma queda mais lenta durante a senescência (efeito "hysteresis"), devido à permanência de material vegetal sobre o solo, o qual tem propriedades refletivas diferentes do solo.

A refletância pode sofrer influência de fatores externos, tais como: horário de leitura, umidade do solo, umidade sobre a superficie das folhas e temperatura dos sensores (Nilsson, 1995). Um exemplo é a queda nos valores de refletância não acompanhada pela queda nos valores de LAI observada aos 84 DAP, nas parcelas com tratamento no campo 5 (Figura 6). Segundo Canteri (1998), isto indica uma dificuldade em se obter modelos transportáveis baseados simplesmente em medidas de refletância e estimula o uso de uma parcela controle, sensu Lopes et al. (1994), para comparar com situações de produção e ser aplicada no manejo integrado da doença.

O horário de realização das leituras de refletância pode provocar grandes variações nos resultados. Em dias sem nebulosidade, ao meio dia solar, observou-se que as folhas do feijoeiro assumem um posicionamento mais ereto e conseqüentemente a refletância é menor para um mesmo LAI. Leituras de refletância realizadas nesse horário têm a vantagem de captar uma maior faixa de LAI. A desvantagem é que isto foi observado apenas em um curto período do dia, ao redor do meio dia e apenas em dias com alta intensidade solar. Portanto, para se aproveitar essa característica, as leituras devem ser executadas sempre nesse mesmo horário sob as mesmas condições de insolação. Outro ponto a ser lembrado é que a intensidade de radiação solar mais intensa exige que o radiômetro esteja calibrado para esta condição (Canteri, 1998).

O tratamento testemunha apresentou menor índice de área foliar e maior severidade de antracnose. Assim, não se pode afirmar qual dos dois fatores colaborou em maior intensidade na variação das leituras de refletância. Em função da literatura (Hatfield, 1990; Aquino et al., 1992; Nilsson, 1995; Canteri et al., 1998) pode-se concluir que o LAI foi o principal responsável, mas permanece a dúvida quanto à sensibilidade de medidas de refletância para detectar níveis de severidade de antracnose. 


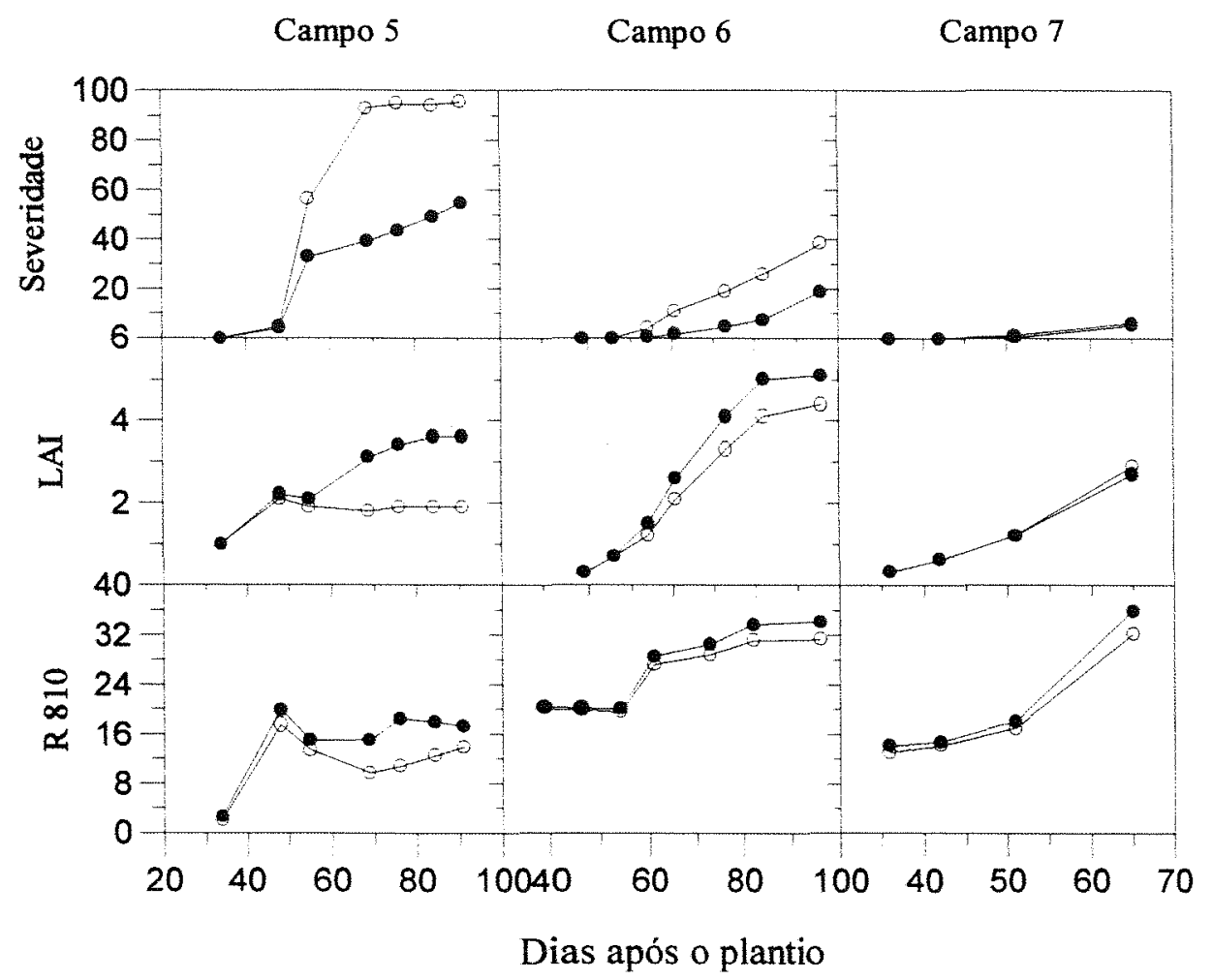

Figura 6 - Severidade de antracnose, índice de área foliar $(L A I)$ e refletância em $810 \mathrm{~nm}$ $\left(R_{810}\right)$ observados em feijoeiro cultivar Carioca, em três épocas de plantio, em parcelas com (círculos cheios) e sem (círculos vazios) controle da doença. Para severidade e LAI cada ponto representa a média para 12 plantas. Para refletância, cada ponto representa a média de 12 amostragens. 


\subsubsection{Relações entre severidade de doença, desfolha e refletância}

Procurou-se relacionar todos os comprimentos de onda avaliados (460, $510,560,610,660,710,760$ e $810 \mathrm{~nm}$ ), índices vegetativos e diferenças normalizadas, $\left(\mathrm{IR} / \mathrm{R}_{610}, \mathrm{IR} / \mathrm{R}_{660}, \mathrm{IR} / \mathrm{R}_{710}, \mathrm{ND}_{810,610}, \mathrm{ND}_{810,660}\right.$ e $\mathrm{ND}_{810,710}$ ) com a severidade de antracnose e a desfolha promovida pela doença. Foram usadas as avaliações semanais realizadas nos três experimentos, para os cinco tratamentos, totalizando 270 observações.

De modo geral, não se conseguiram, boas relações entre as leituras de refletância obtidas e severidade de antracnose ou desfolha promovida pelo patógeno. Os melhores resultados foram obtidos por meio de regressão linear. Para severidade e desfolha, as melhores equações ajustadas foram: Severidade $=20,566-0,1647 * R_{710}$, $R^{2}=38,10$; Desfolha $=19,7201-0,1723 * R_{710}, R^{2}=28,50$.

A análise conjunta dos dados obtidos nos três experimentos não demonstrou resultados animadores. Deste modo, procurou-se verificar tais relações descritas acima para cada experimento isoladamente. Para severidade, apenas no campos 5, obteve-se melhor correlação. A equação ajustada foi:

Severidade $=33,55-0,3161 * R_{710}, R^{2}=85,73$. O mesmo comportamento foi observado para a desfolha, obtendo-se a equação: Desfolha $=25,5785-0,2489 * R_{710}$, $\mathrm{R}^{2}=46,51$. Estes resultados sugerem pouca sensibilidade das medidas de refletância para estimar severidade de doença ou desfolha a nível de campo, e estão de acordo com as observações de Canteri (1998). As melhores correlações obtidas para o campo 5 podem ser explicadas pela maior severidade de doença ocorrida neste experimento, conforme pode ser observado na Figura 6. Essa peculiaridade contribui para validação da hipótese levantada acima, onde somente para altas severidades de doença ou altas percentagens de desfolha consegue-se estimá-las por meio de medidas de refletância. Entretanto, nessas situações deve-se atentar para a maior possibilidade de interferência do solo ou de folhas caídas sob este, nas medidas de refletância (Hatfield, 1990). 
Conforme sugerido por Canteri (1998), procurou-se verificar a influência da severidade da doença nas leituras de refletância sob condições de campo em parcelas com LAI igual ou superior a 3,6 , isto é, onde praticamente não existe interferência da refletância do solo nas avaliações. Entre todos os comprimentos de onda e combinações testadas, a melhor relação de refletância com a severidade de doença no campo foi a $\mathrm{ND}_{810,660}$ (Figura 7) $\left(\mathrm{R}^{2}=71,38 \% ; \mathrm{P}<0,001\right)$. Para $\mathrm{o}$ comprimento de onda de $710 \mathrm{~nm}$, não se encontrou relação tão consistente quanto a verificada para o campo 5. Entretanto, boas correlações para severidade de doença para LAI igual ou superior a 3,6, são pouco úteis em sistemas de manejo de doença do feijoeiro; tais índices são pouco freqüentes na cultura e quando ocorrem, são atingidos mais proximamente ao final do ciclo de cultivo, época em que a tomada de decisão já é tarde.

Com base nos resultados acima, sugere-se que não houve um comprimento de onda ou um índice vegetativo que pudesse ser usado para estimar com segurança apenas a severidade de doença ou percentagem de desfolha a nível de campo, principalmente quando em baixas severidades. Entretanto, conforme opinaram Waggoner \& Berger (1987), medições de área foliar sadia são mais úteis aos propósitos de manejo da doença do que medidas de severidade de doença. Portanto, resta a esperança de maiores sucessos nas relações entre medidas de refletância com as variáveis representativas da área foliar.

\subsubsection{Relações entre refletância e variáveis de área foliar}

De maneira análoga à utilizada para severidade e desfolha, procurou-se relacionar todos os comprimentos de onda avaliados $(460,510,560,610,660,710,760$ e $810 \mathrm{~nm}$ ) e todos os índices vegetativos e diferenças normalizadas (IR/R $R_{610}, I R / R_{660}$, IR/R $\mathrm{R}_{710}, \mathrm{ND}_{810,610}, \mathrm{ND}_{810,660}$ e $\mathrm{ND}_{810,710}$ ) com as variáveis derivadas da área foliar LAI, HLAI e HRI. 


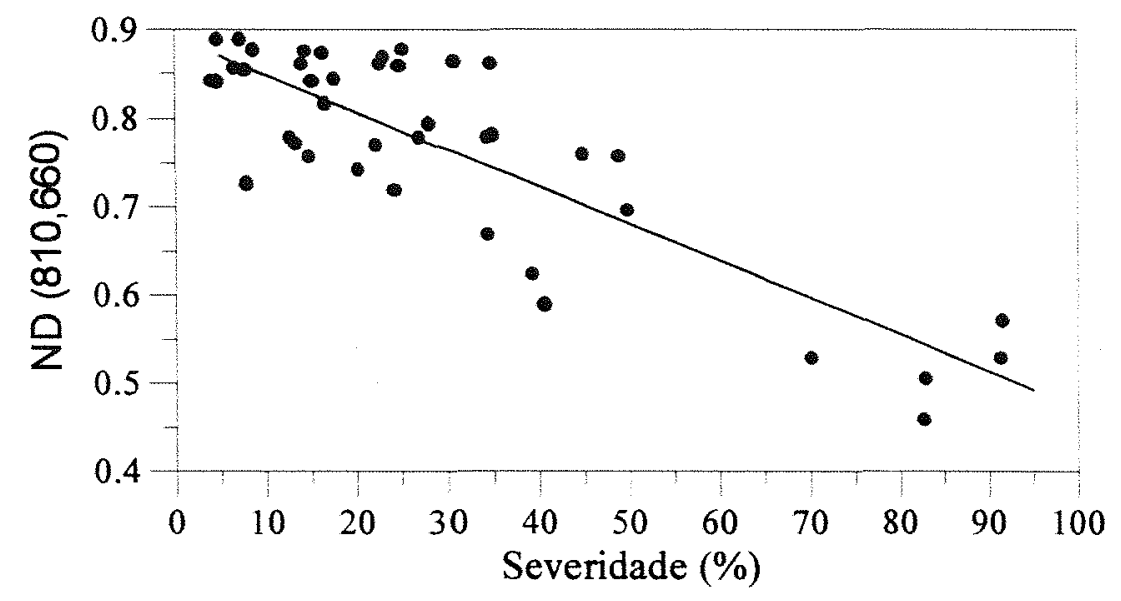

Figura 7 - Severidade de antracnose versus refletância, representada pela diferença normalizada $\left(N D_{810,610}\right)$ utilizando os comprimentos de onda 810 e $610 \mathrm{~nm}$, observadas para copa de feijoeiro com índice de área foliar superior a 3,6. A reta representa a equação ajustada: $\mathrm{y}=0,8909-0,0042 * \mathrm{x}, \mathrm{R}^{2}=71,38 \%$.

Os melhores resultados estão apresentados na Tabela 5. Estes foram obtidos pelo ajuste do modelo linear na refletância de 760 e $810 \mathrm{~nm}$ e pela diferença normalizada, $\mathrm{ND}_{810,660}$.

Para LAI, o ajuste do modelo linear proporcionou coeficientes de determinação que variaram de 23 a $38 \%$; 64 a $79 \%$ e 54 a $89 \%$ para os campos 5 , 6 e 7, respectivamente. Para HLAI, esses coeficientes variaram, respectivamente, da 
seguinte maneira: 45 a $56 \%$; 63 a $72 \%$ e 56 a $88 \%$. O mesmo comportamento foi observado para HRI: 42 a $48 \%$; 67 a $78 \%$ e 66 a $86 \%$. Notou-se, de maneira geral, que os coeficientes de determinação piores foram os obtidos para os resultados do campo 5 e os melhores foram aqueles originários do campo 7 .

Estes coeficientes não foram tão altos quantos aqueles obtidos por Canteri et al. (1998), principalmente quando se tinham maiores severidades de doença no experimento, conforme demonstram as relações obtidas para o campo 5 , e as severidades de doença observadas na Figura 6. Nesta situação, dentre as causas capazes de afetar a refletância enumerada por Canteri et al. (1998), acredita-se que a refletância do solo tenha sido a grande responsável pelos piores resultados apresentados pelo campo 5. Outro fator que deve ser lembrado são as folhas caídas ao chão ou as necrosadas ainda aderidas à planta, que podem apresentar refletância diferente da apresentada pela copa sadia da planta ou do solo (Hatfield, 1990).

Semelhantemente ao observado por Canteri (1998), não houve nos experimentos grande diferença dos resultados obtidos para LAI e HLAI, apesar dos altos índices observados para severidade de antracnose, ou seja, a principal influência da doença deu-se na diminuição do crescimento da planta e queda de folhas e não na redução de área foliar sadia pelas lesões.

Canteri (1998) observou que, para HRI, o ajuste obtido com o uso da $\mathrm{ND}_{810,610}$ foi bem melhor que o observado para $\mathrm{R}_{810}$, confirmando o exposto por Hatfield (1990), ou seja, a diferença normalizada (ND) se relaciona bem com a interceptação de radiação fotossinteticamente ativa, enquanto a refletância na faixa do infravermelho apresenta melhor relação com o índice de área foliar. Nestes experimentos não se observou tal comportamento. Destaca-se, entretanto, que embora tenha sido pequena a diferença entre os coeficientes de determinação encontrados para as relações entre refletância e HLAI e para refletância e HRI, melhores relações para refletância na faixa do infravermelho, em especial, em $810 \mathrm{~nm}$, foram observadas para HLAI do que para HRI, estando, portanto, de acordo pelo menos em parte com o trabalho de Hatfield (1990). 
Por outro lado, Nutter Jr. \& Cunfer (1988); Nutter Jr. (1989) e Aquino et al. (1992), verificaram que a refletância em comprimentos de onda do infravermelho, $\mathrm{R}_{800}$, apresentou boas relações com HLAI. Isto subsidia os resultados obtidos neste trabalho, bem como sugere confiança em modelos para se estimar LAI ou HLAI, que utilizem a refletância na faixa do infravermelho.

\subsubsection{Modelo para estimar HLAI}

A HRI é a variável que melhor se relaciona com a produção (Bergamin Filho et al., 1997); portanto, seria a mais indicada para uso em programas de manejo de doenças. Porém, a HRI depende da radiação solar incidente $(I)$ e esta pode variar entre estações de cultivo. Assim, procurou-se obter um modelo para estimar HLAI, que pudesse, juntamente com dados de radiação solar incidente, ser utilizado para calcular a HRI. A variável de refletância utilizada para o modelo foi o índice vegetativo $R_{810}$, que havia demonstrado a melhor relação com HLAI. Para obtenção do modelo foram utilizados dados de todos os experimentos conjuntamente, evitando-se a influência dos estágios finais na refletância. $\mathrm{O}$ modelo obtido está representado na Figura 8. O R obtido, $62,1 \%$, foi menor que os maiores $\mathrm{R}^{2}$ da relação HLAI x $\mathrm{R}_{810}(71$ e $88 \%$ ) observado para os campos 6 e 7. Isto pode ser devido a inclusão dos dados do campo 5 , pelos quais a intensa severidade de doença proporcionou menor coeficiente de determinação.

O modelo apresentado necessita ser validado para que possa ser recomendado para outras situações de cultivo. Schuld (1996) encontrou variação em medidas de refletância de acordo com variedade e estação de cultivo. Além disto, vários fatores podem influenciar os dados espectrais, tais como quantidade de pigmentos (clorofila), ângulo das folhas, textura da superficie das folhas, doenças e outros estresses, estádio de crescimento das plantas, condição de cultivo, ângulo do sol, tipo de solo e outras condições mensuráveis (Nilsson, 1995). E também deve-se 
lembrar que qualquer modelo, para que tenha aplicação, deve ser validado com dados diferentes daquele que o originou (Kranz \& Royle, 1978).

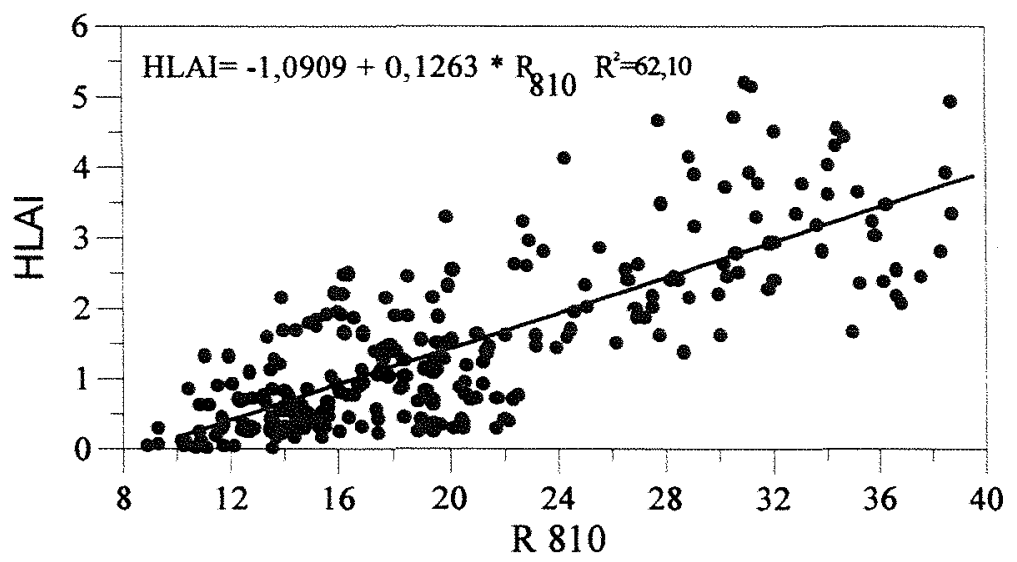

Figura 8 - Modelo para estimativa do índice de área foliar sadia (HLAI) em função da refletância no comprimento de onda de $810 \mathrm{~nm}$.

4.4.5 Relações da produção com variáveis de área foliar, doença e refletância

Para a verificação dessas relações, utilizou-se apenas dos dados obtidos para os campos 5 e campo 6 . Esta atitude deve-se ao fato das medidas de refletância obtidas para o campo 7 terem sido tomadas apenas na fase inicial de seu ciclo de cultivo (Figura 6). Isto fez com que as relações de produção com medidas de refletância se tornassem mais consistentes. 
Tabela 5 - Parâmetros estimados e coeficiente de determinação $\left(\mathrm{R}^{2}\right)$ do modelo linear $(\mathrm{Y}=\mathrm{A}+\mathrm{B} * \mathrm{X})$ ajustado aos valores de refletância, variável dependente, plotados contra o índice de área foliar, LAI, índice de área foliar sadio, HLAI, e absorção de área foliar sadia por unidade de tempo, HRI, para os campo 5,6 e 7 .

\begin{tabular}{|c|c|c|c|}
\hline & $\mathbf{A}$ & $\bar{B}$ & $\mathbf{R}^{2}$ \\
\hline \multicolumn{4}{|c|}{ LAI - Campo 5} \\
\hline $\mathrm{R}_{760}$ & 4,6494 & 3,0627 & 38,07 \\
\hline $\mathrm{R}_{810}$ & 5,0307 & 3,4124 & 34,13 \\
\hline $\mathrm{ND}_{810,660}$ & 0,3812 & 0,0525 & 23,45 \\
\hline \multicolumn{4}{|c|}{ LAI - Campo 6} \\
\hline $\mathrm{R}_{760}$ & 16,7544 & 3,0175 & 79,01 \\
\hline$R_{810}$ & 18,1049 & 2,8322 & 77,15 \\
\hline $\mathrm{ND}_{810,660}$ & 0,5142 & 0,0717 & 64,30 \\
\hline \multicolumn{4}{|c|}{ LAI - Campo 7} \\
\hline $\mathrm{R}_{760}$ & 10,2964 & 7,6436 & 88,30 \\
\hline $\mathbf{R}_{810}$ & 10,5194 & 8,3431 & 89,45 \\
\hline $\mathrm{ND}_{810,660}$ & 0,6137 & 0,0452 & 54,08 \\
\hline \multicolumn{4}{|c|}{ HLAI - Campo 5} \\
\hline $\mathrm{R}_{760}$ & 10,6819 & 2,2977 & 45,18 \\
\hline $\mathrm{R}_{810}$ & 11,6104 & 2,8244 & 53,23 \\
\hline $\mathrm{ND}_{810,660}$ & 0,4137 & 0,0829 & 56,49 \\
\hline \multicolumn{4}{|c|}{ HLAI - Campo 6} \\
\hline $\mathrm{R}_{760}$ & 16,7776 & 3,6621 & 72,35 \\
\hline $\mathrm{R}_{810}$ & 18,1118 & 3,4446 & 71,59 \\
\hline $\mathrm{ND}_{810,660}$ & 0,5078 & 0,0905 & 63,40 \\
\hline \multicolumn{4}{|c|}{ HLAI - Campo 7} \\
\hline$R_{760}$ & 9,8972 & 8,3499 & 88,13 \\
\hline $\mathrm{R}_{810}$ & 10,1057 & 9,0951 & 88,20 \\
\hline $\mathrm{ND}_{810,660}$ & 0,6103 & 0,0503 & 56.79 \\
\hline \multicolumn{4}{|c|}{ HRI - Campo 5} \\
\hline $\mathrm{R}_{760}$ & 10,093 & 0,6219 & 43,10 \\
\hline $\mathrm{R}_{810}$ & 11,0088 & 0,7388 & 48,15 \\
\hline $\mathrm{ND}_{810,660}$ & 0,3933 & 0,0212 & 42,45 \\
\hline \multicolumn{4}{|c|}{ HRI - Campo 6} \\
\hline $\mathrm{R}_{760}$ & 13,4944 & 1,1828 & 69,30 \\
\hline $\mathrm{R}_{810}$ & 15,0589 & 1,1086 & 67,48 \\
\hline $\mathrm{ND}_{810,660}$ & 0,3898 & 0,0333 & 78,50 \\
\hline \multicolumn{4}{|c|}{ HRI - Campo 7} \\
\hline $\mathrm{R}_{760}$ & 6,3713 & 1,8068 & 86,13 \\
\hline $\mathrm{R}_{810}$ & 6,3048 & 1,9621 & 85,20 \\
\hline $\mathrm{ND}_{810,660}$ & 0,5811 & 0,0119 & 66,39 \\
\hline
\end{tabular}


Como esperado, a produção correlacionou-se bem com as variáveis representativas da área foliar, o que possibilita sua utilização para estimar danos provocados pela antracnose do feijoeiro e, conseqüentemente, ser utilizada para sistemas de manejo de doença (Nunes \& Bergamin Filho, 1996; Carneiro, 1995; Iamauti, 1995; Godoy, 1995; Canteri et al., 1998). A duração de área foliar sadia (HAD) apresentou um $\mathrm{R}^{2}=79,05 \%$ e a absorção de área foliar sadia (HAA) um $\mathrm{R}^{2}=$ $85,71 \%$ (Figura 8).

A área sob a curva de progresso da doença (AUDPC), variável geralmente utilizada para relações com danos (Bergamin Filho \& Amorim, 1996), apresentou o menor coeficiente de determinação, $\mathrm{R}^{2}=77,75 \%$ na relação com a produção, embora tenha sido bastante alto, perante os ensaios que se utilizem da metodologia de plantas individuais.

Quanto às medidas de refletância, as melhores relações foram encontradas para $\mathrm{AUR}_{610}, \mathrm{AUR}_{760} \mathrm{e} \mathrm{AUR}_{810}$. Estes resultados foram bastante superiores aos encontrados para a integral do índice vegetativo, $\operatorname{AUR}_{\mathrm{ND}(810,660) \text {, para }}$ relações com a produção. Estes resultados diferem dos obtidos por Canteri et al. (1998) e do exposto por Hatfield (1990), ou seja, a diferença normalizada (ND) se relaciona bem com a interceptação de radiação fotossinteticamente ativa e conseqüentemente com a produção. A nítida diferença na distribuição dos pontos observados na Figura 9 pode ser atribuída às maiores severidades de doença observadas no campo 5 , o que redunda em menores $\mathrm{HAD}$ e HAA, quando comparados aos observados para o campo 6. Entretanto, observa-se que a reta ajustada adapta-se às observações dos campos 5 e 6.

4.4.6 Sensibilidade de medidas de refletância para verificar a eficiência dos tratamentos 
Os tratamentos realizados objetivaram promover uma ampla gama de níveis de severidade de antracnose, e conseqüentemente, variações na área foliar e na produção. Entretanto, não houve diferenças significativas, pelo teste de Tukey $(\mathrm{P}<0,05)$, para absorção da área foliar sadia $(\mathrm{HAA})$, em nenhum dos experimentos (Tabela 6). Resultados semelhantes foram observados para AUDPC e para AUR 810 , para os campos 6 e 7. Por outro lado, para o campo 5, diferenças significativas foram observadas para tanto na AUDPC quanto na $A R_{810}$. A ausência de diferenças significativas para essas variáveis pode ser explicada pelo pouco efeito da quantidade de doença sobre a área foliar neste ensaio.

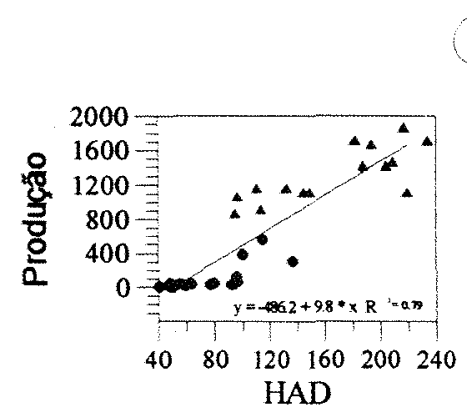

\section{- Campo 5 Campo 6}
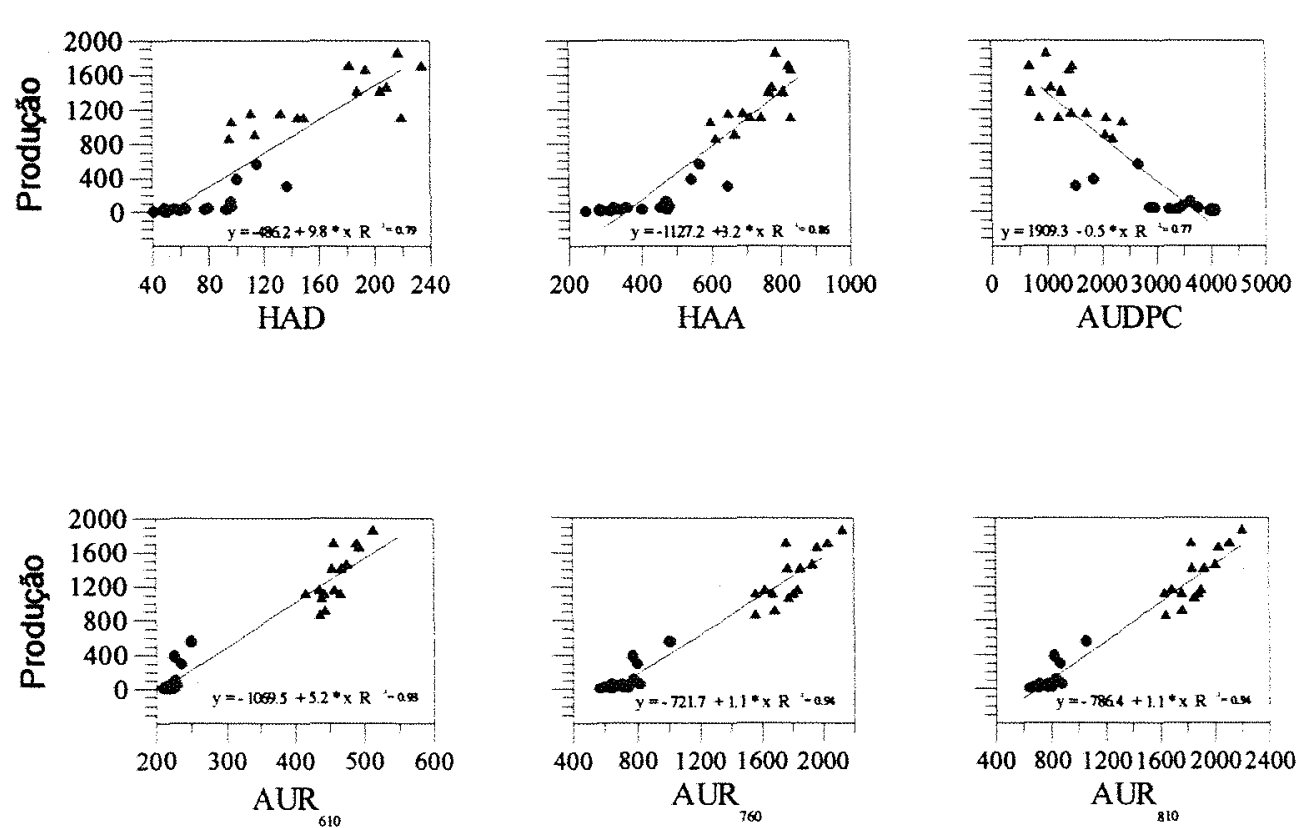

Figura 9 - Relações da produção, g parcela ${ }^{-1}\left(6 \mathrm{~m}^{2}\right)$, com duração de área foliar sadia (HAD), absorção de área foliar sadia (HAA), área sob a curva de progresso da doença (AUDPC), integral da refletância em 610, 760 e $810 \mathrm{~nm}$ $\left(\mathrm{AUR}_{610}, \mathrm{AUR}_{760}\right.$ e $\mathrm{AUR}_{810}$ ). 
Para AUDPC a parcela controle, tratamento 1, foi a única que se apresentou diferente dos demais tratamentos, apresentando a menor área abaixo da curva de progresso de doença. Os dados de refletância apresentaram a mesma tendência, sendo, neste caso, a refletância apresentada pela parcela controle superior às demais.

Para produção verificou-se que apenas para o campo 6 não houve diferenças em produtividade. Para o campo 7, verificaram-se algumas diferenças na produção. Entretanto, tanto HAA, como a AUDPC foram estatisticamente semelhantes, e, portanto, as diferenças encontradas para produtividade provavelmente não são atribuídas à antracnose ou a diferenças em área foliar. Os resultados apresentados para o campo 5 apresentaram-se consistentes e de acordo com o esperado, ou seja, a parcela controle, tratamento 1 , apresentou menor AUDPC, maior refletância e conseqüentemente maior produção. A produção neste experimento esteve diretamente relacionada à intensidade de aplicação das medidas de controle, ou seja, a parcela controle, com intervenção semanal com o fungicida, apresentou maior produtividade, ao passo que a testemunha, sem controle, apresentou a menor produtividade. Os demais tratamentos apresentaram produções intermediárias e podem ser vistos na Tabela 6.

O coeficiente de variação observado para as variáveis HAA e AUR 810 foi relativamente baixo, entre 6,3 a $18,3 \%$ e 4,7 a $7,5 \%$, respectivamente, demonstrando boa precisão para o experimento (Gomes, 1987). Estes valores são bem menores do que aqueles obtidos para a AUDPC, 11,6 a 43,5, o que indica mais uma vantagem na utilização de HAA ou AUR $_{810}$ sobre AUDPC para comparações entre tratamentos, como por exemplo em experimentos para verificação da eficiência de fungicidas. 
Tabela 6 - Absorção de área foliar sadia (HAA), área sob a curva de progresso de antracnose (AUDPC), área sob a curva de refletância na faixa de $810 \mathrm{~nm}$ $\left(A U R_{810}\right)$ e produtividade de feijoeiro, observadas para três épocas plantio.

\begin{tabular}{|c|c|c|c|c|}
\hline Tratamento & HAA & AUDPC & $\mathrm{AUR}_{810}$ & Produção \\
\hline \multicolumn{5}{|l|}{ Campo 5} \\
\hline 1 & 586,8 a & 2034,2 a & 920,7 a & 408,3 a \\
\hline 2 & $418,5 \mathrm{a}$ & $3498,6 \mathrm{~b}$ & $738,6 \quad b$ & 62,0 bc \\
\hline 3 & 375,1 a & $3501,9 \mathrm{~b}$ & $814,8 \mathrm{ab}$ & $38,1 \quad \mathrm{c}$ \\
\hline 4 & 399,7 a & $3185,4 b$ & $787,8 \mathrm{ab}$ & 31,1 \\
\hline 5 & 306,3 a & $3921,7 \mathrm{~b}$ & $694,8 \quad b$ & 16,6 \\
\hline CV $(\%)$ & 18,3 & 11,6 & 7,5 & 54,7 \\
\hline \multicolumn{5}{|l|}{ Campo 6} \\
\hline 1 & $791,0 \mathrm{a}$ & 792,8 a & 1988,5 a & $1650,0 \mathrm{a}$ \\
\hline 2 & $697,2 \mathrm{a}$ & $1691,6 \mathrm{a}$ & 1789,7 a & $1216,7 \mathrm{a}$ \\
\hline 3 & $711,7 \mathrm{a}$ & $1574,2 \mathrm{a}$ & $1866,7 \mathrm{a}$ & 1283,3 a \\
\hline 4 & $793,7 \mathrm{a}$ & $1524,2 \mathrm{a}$ & 1829,8 a & $1200,0 \mathrm{a}$ \\
\hline 5 & $711,7 \mathrm{a}$ & $1626,7 \mathrm{a}$ & 1893,7 a & $1166,7 \mathrm{a}$ \\
\hline C V (\%) & 7,0 & 25,7 & 7,1 & 14,9 \\
\hline \multicolumn{5}{|l|}{ Campo 7} \\
\hline 1 & 783,9 a & 38,9 a & 867,8 a & $2400,0 \quad b$ \\
\hline 2 & 762,4 a & 97,0 a & 886,1 a & $2183,3 a b$ \\
\hline 3 & 754,7 a & 75,3 a & 821,7 a & $2083,3 \mathrm{ab}$ \\
\hline 4 & 805,2 a & 79,8 a & 877,7 a & $2116,7 \mathrm{ab}$ \\
\hline 5 & 802,3 a & 56,4 a & 892,8 a & 1983,3 a \\
\hline C V $(\%)$ & 6,3 & 43,2 & 4,7 & 6,4 \\
\hline
\end{tabular}

Médias seguidas de mesma letra não diferem estatisticamente entre si pelo teste de Tukey $(\mathrm{P}<0,05)$.

C V-Coeficiente de variação 
A arquitetura da copa de uma planta é função do arranjamento espacial dos órgãos aéreos, que em conjunto formam a copa das plantas (Hatfield, 1990; Nutter Jr. \& Littrell, 1996). Folhas e outros órgãos que realizam fotossintese, atuam como coletores de energia solar; deste modo, a arquitetura da copa afeta a quantidade e qualidade da radiação solar que é refletida, transmitida ou absorvida. Outro fato que deve ser ressaltado, é que a estrutura da copa é dinâmica através da estação de crescimento, com alterações na população de folhas, que geralmente aumentam durante a ciclo da cultura. Entretanto, a adição de novas folhas pode ser anulada pela desfolha, que pode ser provocada pelo patógeno, pela alimentação de insetos ou pela própria senescência da planta (Nutter Jr. \& Littrell, 1996). Deste modo, a arquitetura obtida pelo stand no campo e a quantidade de produção são funções do crescimento da planta através do tempo. Este processo geralmente é de dificil mensuração, porque tanto o crescimento do hospedeiro como a quantificação da severidade de doença demandam imensa intensidade de trabalho. A taxa de crescimento das plantas geralmente é proporcional à quantidade de radiação interceptada pelas suas copas (Waggoner \& Berger, 1987); deste modo, o índice de área foliar sadia, HLAI, ou absorção da área foliar sadia por unidade de tempo, HRI, juntamente com suas integrais, HAD e HAA, apresentam alta relação com produção.

Para o patossistema feijão/antracnose, os resultados de refletância, quando relacionados à desfolha ou à severidade de doença, não foram tão precisos e acurados quantos os observados por Nutter Jr. \& Littrell (1996). Entretanto, esses autores comentam que medidas de refletância em $800 \mathrm{~nm}$ podem fornecer uma estimativa indireta de HLAI, o que pode explicar porque essas medidas apresentam melhores relações com refletância do que a obtida com desfolha ou severidade de doença. Observou-se, também, que as medidas de refletância, podem ser utilizadas para a elaboração de um modelo para se estimar HLAI, com razoável precisão. Medidas de refletância são mais fáceis e rápidas de serem obtidas do que avaliações de severidade de doença ou área foliar, e, como já observado, apresentam razoáveis relações com LAI, HLAI ou HRI, e, conseqüentemente, com produção. Por último, observou-se que 
modelos baseados na área abaixo da curva de progresso da refletância, utilizando os comprimentos de onda de 610,760 e $810 \mathrm{~nm}$, explicaram mais de $93 \%$ da variação na produção.

Deve-se ressaltar que, para programas de manejo de doenças, a utilização de modelos integrais apresenta algumas desvantagens: a principal é a necessidade de serem realizadas, no mínimo, duas avaliações espaçadas no tempo, para poder ser utilizada em processos de tomada de decisão. Neste contexto, a utilização de medidas de refletância parece simplificar muito o processo e mesmo minimizar tal desvantagem. Por outro lado, a utilização de medidas de refletância, como variável independente em modelos de ponto crítico, pode ser o melhor caminho a seguir. Como demonstrado neste ensaio, a possibilidade da utilização de medidas instantâneas de refletância, ao invés de modelos baseados em variáveis derivadas da área foliar, como HLAI ou HRI, para um sistema de manejo da antracnose do feijoeiro, é viável. Resta, pois, a validação e o refinamento do modelo baseado em medidas de refletância para estimativa de HLAI e conseqüente quantificação de dano, para implementação de um sistema de manejo da antracnose do feijoeiro baseado no limiar de dano econômico. 


\section{ANTRACNOSE DO FEIJOEIRO: EFEITO DO TRIFENIL ACETATO DE ESTANHO NO CRESCIMENTO DO HOSPEDEIRO E NO PROGRESSO DA DOENÇA}

\subsection{RESUMO}

Foram conduzidos três experimentos com feijoeiro cultivar 'Carioca', para se investigar o comportamento da severidade de doença, desfolha, área sob a curva de progresso da doença (AUDPC), índice de área foliar (LAI), índice de área foliar sadia (HLAI), absorção da radiação pela área foliar sadia por unidade de tempo (HRI), duração da área foliar sadia (HAD), absorção da área foliar sadia (HAA) e produção, após intervenção no patossistema feijão/antracnose (Colletotrichum lindemuthianum) com o fungicida trifenil acetato de estanho em dosagem de $0,2 \mathrm{~kg} / \mathrm{ha}$. Os tratamentos foram: 1 - pulverizações semanais iniciadas iniciadas uma semana após a inoculação; 2 - pulverizações no estádio $R_{5}$ e 14 dias após; 3 - pulverização no estádio $R_{5} ; 4$ testemunha. Os resultados demonstraram reduções significativas na severidade de doença e desfolha do hospedeiro, após o início das pulverizações na parcela controle. A AUDPC forneceu uma adequada medida cumulativa da severidade de doença, combinando os efeitos da taxa de progresso da doença e crescimento contínuo do hospedeiro. Destacou-se com menores AUDPC $(\mathrm{P}<0,05)$ o tratamento da parcela controle. Não se observaram diferenças entre os valores de LAI para os tratamentos. Entretanto, os valores de HLAI e HRI apresentaram diferença estatisticamente 
significativa. Maiores absorções de radiação resultaram em maiores produtividades. As avaliações semanais dos valores de HLAI e HRI demonstraram que a severidade de doença e/ou a desfolha os influenciam negativamente. Entretanto, essas variáveis responderam positivamente ao tratamento com o fungicida, indicando o potencial do emprego de variáveis derivadas da área foliar em um sistema de manejo da antracnose do feijoeiro baseado num limiar de dano econômico.

\subsection{INTRODUÇÃO}

A antracnose do feijoeiro tem como agente causal Colletotrichum lindemuthianum e é uma das mais importantes doenças dessa cultura em todo o mundo (Schwartz, 1994). O patógeno causa lesões nas folhas, pecíolos, caules e vagens, podendo causar severa desfolha quando ocorre a completa necrose foliar. $\mathrm{Na}$ ausência de medidas de controle, cultivares suscetíveis, estabelecidas em localidades com temperatura moderada à baixa e alta umidade relativa (Rava et al., 1998) podem sucumbir perante uma epidemia da doença. Os danos ocasionados pela antracnose podem ser de até $100 \%$, principalmente quando são semeadas sementes infectadas e as condições de ambiente são favoráveis (Rava et al., 1998; Sartorato, 1988).

Estudos relativos a danos causados pelo patógeno, geralmente, baseiamse em relação quantitativa entre severidade de doença e produção (James, 1974). Deste modo, vários modelos, que prevêem danos baseados na severidade de doença, têm sido desenvolvidos para algumas culturas. Por outro lado, Watson (1947) cita que produção é melhor relacionada com duração da área foliar sadia (HAD). Waggoner \& Berger (1987) refinaram o conceito no qual produção relaciona-se com duração da área foliar sadia (HAD), encontrando melhores relações de produção com a absorção da área foliar sadia (HAA), a qual é a integral da absorção da área foliar sadia por unidade de tempo (HRI), durante a estação de crescimento da cultura. Essa metodologia, utilizada em 
trabalhos prévios para alguns dos patossitemas do feijoeiro, tem demonstrado maior eficiência do que aquelas que se baseiam em severidade de doença (Lopes et al., 1994; Nunes \& Bergamin Filho, 1996; Carneiro, 1995; Iamauti, 1995; Godoy, 1995; Bergamin Filho et al., 1997; Canteri et al., 1998).

A metodologia baseada nos conceitos de Waggoner \& Berger (1987) necessita de avaliações de área foliar, as quais, muitas vezes, demandam enorme intensidade de trabalho e às vezes não são possiveis de serem realizadas sem a destruição da amostra. Para contornar esse problema, alguns trabalhos têm demonstrado a possibilidade da utilização de técnicas de sensoriamento remoto, principalmente aquelas baseadas em radiômetro de múltiplo espectro, em modelos para estimativa de HLAI ou produção (Nutter Jr., 1989; Aquino et al., 1992; Nilsson, 1995; Canteri et al., 1998).

A quantificação de danos baseada na área foliar sadia remanescente foi utilizada no patossitema feijão/mancha angular por Bergamin Filho et al. (1997) para propor um sistema de manejo integrado de doença, que tem como pedra fundamental o limiar de dano econômico, LDE, definido como a menor diferença entre HLAI ou HRI de uma parcela controle em uma situação de produção, na qual os benefícios advindos de uma medida de controle se igualam aos custos da operação. Entretanto, estes autores encontraram duas dificuldades para implementação do sistema de manejo: $i$ ) trabalho requerido para estimativas de HLAI e HRI; ii) a inexistência de dados relativos a medidas de controle sobre a severidade de doença e sobre HLAI, o qual é a variável utilizada para a definição do LDE. A primeira dificuldade citada encontra-se contornada pela utilização de modelos que têm como variável independente a refletância da copa do feijoeiro e como variável dependente HLAI, que juntamente com os dados de radiação permite estimar HRI. Tratando-se do patossistema feijão/mancha angular, um bom modelo foi proposto por Canteri et al. (1998). Resultados semelhantes foram obtidos no patossistema feijão/antracnose. Já a inexistência de informações sobre o comportamento do patógeno e do hospedeiro, após intervenção no patossistema com uma medida de controle, ainda é um ponto obscuro aos fitopatologistas. 
Ao se pensar em medidas de controle em sistema integrado de manejo de doenças, elas devem passar pela escolha do local, época de plantio, escolha da cultivar, espaçamento, qualidade das sementes, utilização de antagonistas e, finalmente, em controle químico. O sistema proposto e discutido acima por Bergamin Filho et al. (1997) deve considerar todos estes aspectos para o controle da doença. Entretanto, uma vez estabelecida a cultura, e tendo-se como o limiar de dano econômico, HRI, resta apenas a possibilidade da profilaxia para evitar que o LDE seja ultrapassado.

Vários estudos têm demonstrado a eficiência de fungicidas para controle da antracnose sob condições de campo. As recomendações atuais preconizam o início dos tratamentos quando aparecem os primeiros sintomas (Sartorato, 1988). São eficientes: maneb (Issa \& Arruda, 1964); zineb (Zambolim \& Chaves, 1978); benomil (Giroto, 1974; Navarro \& Puerta, 1983) carbendazin (Giroto, 1974; Bianchini et al., 1978); mancozeb (Issa \& Arruda, 1964); chlorothalonil (Bianchini et al., 1978; Navarro \& Puerta, 1983); trifenil acetato de estanho (Thomson, 1973; Mohan et al., 1981); hexaconazole + chlorothalonil (De Vincenzo et al., 1995); tebuconzole (Galli et al., 1995); azoxystrobin (Adoryan et al., 1996). Dentre estes fungicidas, o de menor custo e de maior utilização por produtores de feijão é o trifenil acetato de estanho, sendo, portanto, o utilizado nesses experimentos.

O objetivo deste trabalho foi acompanhar o comportamento do progresso da severidade de doença e o crescimento do hospedeiro, por meio de variáveis derivadas do índice de área foliar, no patossistema feijão/antracnose, após intervenções de controle baseadas em pulverizações com o fungicida trifenil acetato de estanho em diferentes épocas. Objetivou-se ainda, verificar a existência de reação das plantas após aplicação de medidas profiláticas aplicadas ao atingir-se um limiar de dano econômico.

\subsection{MATERIAL E MÉTODOS}

\subsubsection{Experimentos em casa de vegetação}


Foram conduzidos dois experimentos durante o ano de 1998, com a cultivar 'Carioca'. Esses ensaios foram realizados nas casas de vegetação da Escola Superior de Agricultura "Luiz de Queiroz", situada em Piracicaba, SP $\left(22^{\circ} \mathrm{S}, 47^{\circ} \mathrm{W}\right.$, altitude de $540 \mathrm{~m}$ ). O plantio dos experimentos deu-se em 5 de março e 7 de abril de 1998, sendo denominadas de época 1 e época 2, respectivamente.

Nas duas épocas, o delineamento experimental foi inteiramente casualizado, com dois tratamentos e dez repetições para a época 1 e oito repetições para época 2. Cada parcela possuía uma planta semeada em vaso com capacidade de 2,5 litros. Esses vasos foram dispostos de maneira aleatória dentro da casa de vegetação. Os tratamentos utilizados foram: $i$ ) aplicação semanal do fungicida trifenil acetato de estanho $0,2 \mathrm{~kg} / \mathrm{ha}$, iniciado 20 dias após o semeio; ii) testemunha sem aplicação de qualquer fungicida. Em ambos os tratamentos não se inoculou qualquer patógeno, sendo, portanto, ambos os experimentos mantidos livres de doença.

A manutenção dos experimentos deu-se por meio de irrigações diárias e aplicação do inseticida metamidofós, quando necessário. A metodologia de avaliação foi a mesma utilizada para os experimentos de campo e encontram-se descritas a seguir.

\subsubsection{Experimentos de campo}

Três experimentos foram conduzidos durante o ano de 1997, com a cultivar 'Carioca'. Esses ensaios foram conduzidos na Estação Experimental Nova Fazenda Hokko, situada na Rodovia SP $143, \mathrm{Km} 8,5$, município de Pereiras, SP ( $23^{\circ} \mathrm{S}$, $60^{\circ} \mathrm{W}$, altitude de $479 \mathrm{~m}$ ). O primeiro experimento foi semeado em 17 de abril de 1997, e foi denominado de campo 5. Os demais foram plantados 30 e 60 dias após o plantio do primeiro, e foram denominados de campo 6 e campo 7, respectivamente.

Em todos os ensaios, utilizou-se do mesmo delineamento experimental, de blocos ao acaso, com quatro tratamentos e três repetições. Cada parcela de $12 \mathrm{~m}^{2}$ possuía quatro linhas de plantio, com seis metros de extensão. O espaçamento entre 
linhas foi de $0,5 \mathrm{~m}$, procurando-se obter uma densidade de 12 plantas por metro linear. A manutenção dos experimentos deu-se por meio de práticas culturais convencionais, utilizadas em campos comerciais, incluindo plantio, adubações, irrigações, quando necessários, e pulverizações com os inseticidas metamidofós e cartap. Estas pulverizações objetivaram deixar os experimentos livres da interferência de pragas e de ferrugem.

Quando os plantios atingiram o estádio $V_{3} / V_{4}$ (Michaels, 1994), procedeu-se à inoculação de todas as parcelas. Para tanto, utilizou-se de isolados de Colletotrichum lindemuthianum, obtidos junto ao Instituto Agronômico do Paraná e a Universidade Federal de Lavras. Esses isolados foram multiplicados em meio de ágarvagem (Benhamon et al., 1991), mantidos por 14 dias sob escuro constante e temperatura de $21^{\circ} \mathrm{C}$. Decorrido esse período, obteve-se uma suspensão de esporos, padronizada em $10^{6}$ esporos $/ \mathrm{ml}$. Esta suspensão foi pulverizada sobre as plantas, utilizando-se pulverizador costal de pressão constante, $40 \mathrm{Lb} /$ pol $^{2}$, aplicando-se $130 \mathrm{ml}$ da suspensão nas duas fileiras centrais de cada parcela. A inoculação foi realizada sempre após as 20:00 h, sendo previamente aspergido água destilada sobre as plantas, de mesmo modo utilizado para a inoculação. Este procedimento objetivou proporcionar molhamento foliar até que fosse atingido o ponto de orvalho e conseqüentemente ocorresse molhamento foliar natural. Isto se deu em função da impossibilidade de colocar câmara úmida em todo o ensaio.

Para estudo do crescimento do hospedeiro e progresso da doença, realizaram-se pulverizações com fungicida à base de trifenil acetato de estanho, em dosagem de $0,2 \mathrm{~kg} / \mathrm{ha}$, em diferentes épocas. $\mathrm{O}$ tratamento 1 consistiu de iniciar as pulverizações uma semana após a inoculação, e repeti-la semanalmente, sendo considerado como parcela controle sensu Lopes et al. (1994). No tratamento 2 realizaram-se pulverizações no estádio $R_{5}$ (Michaels, 1994), repetindo-se uma única vez após 14 dias. No tratamento 3 realizou-se pulverização no estádio $R_{5}$ (Michaels, 
1994). No tratamento 4, testemunha, não se realizou controle da antracnose do feijoeiro.

\subsubsection{Crescimento do hospedeiro, severidade de doença e produção}

Crescimento do hospedeiro, severidade de doença e produção foram avaliados nas duas fileiras centrais de cada parcela. Em cada parcela foram marcadas 4 plantas com fita plástica colorida no estádio $V_{3} / V_{4}$ (Michaels, 1994). Procurou-se selecionar plantas com tamanho e vigor semelhantes. Nessas plantas marcaram-se todas as folhas, que foram surgindo com o auxílio de uma etiqueta de papel numerada, embebida em parafina. As folhas foram numeradas objetivando-se quantificar a desfolha promovida pelo patógeno.

A área foliar (LA, $\mathrm{cm}^{2}$ ) de todas as folhas de cada planta marcada foi estimada semanalmente, iniciando-se no estádio $\mathrm{V}_{3} / \mathrm{V}_{4}$ (Michaels, 1994). Para isto, a maior largura do folíolo central de cada folha $(L, \mathrm{~cm})$ foi medida com o auxílio de uma régua. A área foliar foi estimada a partir da relação empírica (Bassanezi, 1995):

$$
\mathrm{LA}=3,03 L^{1,87}, \mathrm{R}^{2}=88 \% \text {. }
$$

A avaliação da severidade da antracnose do feijoeiro foi realizada simultaneamente à avaliação de área foliar com auxílio de uma escala diagramática de severidade (Godoy et al., 1997), com a qual a percentagem média de severidade para os três folíolos de todas as folhas das plantas marcadas foi avaliada.

A desfolha do hospedeiro foi quantificada entre avaliações consecutivas. Para tanto, quando folíolos ou folhas atingiam $100 \%$ de necrose, ou se apresentavam caídos em função do patógeno, suas respectivas áreas foliares foram consideradas como desfolha. Estes dados foram computados para obtenção da área foliar total das plantas. Em seguida, os dados de desfolha foram utilizados para cálculo da percentagem de desfolha (DF, \%) tomando-se como referência a área foliar total das plantas: 


$$
\mathrm{DF}=(\text { Área desfolhada } / \text { Área foliar total }) * 100
$$

A produção foi determinada para cada planta marcada, ao final do ciclo da cultura, pesando-se as sementes com $12 \%$ de umidade. Os resultados foram expressos em g planta ${ }^{-1}$.

\subsubsection{Variáveis integrais e taxa de progresso da doença}

A AUDPC para cada planta marcada foi calculada por integração trapezoidal:

$$
\mathrm{AUDPC}=\sum_{i=1}^{n-1}\left[\left(X_{i}+X_{i+1}\right) / 2\right]\left(t_{i+1}-t_{i}\right)
$$

Em que $X$ é a severidade média da doença (porcentagem), $X_{\mathrm{i}}$ é a severidade no tempo $t_{i}$; $n$ é o número de avaliações e $\left(t_{i+1}-t_{i}\right)$ é o intervalo entre duas avaliações consecutivas. $O$ cálculo da AUDPC foi realizado, quando se considerou a desfolha promovida pelo patógeno para estimativa de $X$.

As taxas aparentes de progresso da doença, $r$, foram obtidas por meio do coeficiente angular à curva de progresso de doença, linearizada transformando-se a severidade de doença em logito de $X$ :

$$
\text { Logito } X=\text { Logito } X_{0}+r t
$$

Em que $X$ é a severidade de doença em proporção e $t$ é o tempo.

Para área abaixo da curva de progresso da área foliar, AULAPC, de cada planta marcada, utilizou-se da integração trapezoidal, de modo semelhante à descrita para AUDPC, diferindo desta pela substituição dos valores de severidade de doença por área foliar da planta, $\mathrm{cm}^{2}$.

Os valores de índice de área foliar (LAI) de cada planta foram obtidos dividindo a área foliar de cada planta, em cada avaliação, pela área ocupada por cada planta $\left(0,0416 \mathrm{~m}^{2}\right)$. A duração da área foliar sadia (HAD) foi calculada pela fórmula 


$$
\mathrm{HAD}=\sum_{i=1}^{n-1}\left\{\left[L A I_{i}\left(1-X_{i}\right)+L A I_{i+1}\left(1-X_{i+1}\right)\right] / 2\right\}\left(t_{i+1}-t_{i}\right)
$$

Em que $\mathrm{LAI}_{\mathrm{i}}$ é o índice de área foliar no tempo $t_{i}$. $\mathrm{O}$ valor do índice de área foliar sadio (HLAI) para cada data de avaliação foi calculado como HLAI = LAI( $1-X)$.

Os valores de radiação interceptada $\left(\mathrm{RI}_{\mathrm{i}}\right) \mathrm{em} \mathrm{MJ} \mathrm{m}^{-2}$ foram calculados como:

$$
\mathrm{RI}_{i}=I_{i}\left[1-\exp \left(-k \mathrm{LAI}_{i}\right)\right]
$$

em que $I_{i}$ é a média de radiação solar incidente $\left(\mathrm{MJ} \mathrm{m}^{-2}\right)$ no período $\left(t_{i+1}-t_{i}\right)$ e $k$ é o coeficiente de extinção; usou-se $k=0,7$ (Miglioranza, 1992; Bergamin Filho et al., 1997). O valor da absorção de área foliar sadia (HAA) em $\mathrm{MJ} \mathrm{m}^{-2}$ foi calculado como:

$\mathrm{HAA}=\sum_{i=1}^{n-1} I_{i}\left(\left\{\left(1-X_{i}\right)\left[1-\exp \left(-k L A I_{i}\right)\right]+\left(1-X_{i+1}\right)\left[1-\exp \left(-k L A I_{i+1}\right)\right]\right\} / 2\right)\left(t_{i+1}-t_{i}\right)$

Os valores de HRI (MJ m${ }^{-2}$ ), para cada data de avaliação, foram calculados pela fórmula HRI $=\mathrm{RI}(1-X)$. A radiação solar incidente $(I)$ foi medida por uma estação meteorológica computadorizada situada a $500 \mathrm{~m}$ da área experimental.

\subsubsection{Análise dos dados}

Os teste de média foram realizados com o auxílio do programa PlotIT for Windows (Scientific Programming Enterprises, Haslsett, MI).

\subsection{RESULTADOS E DISCUSSÃO}

\subsubsection{Experimentos em casa de vegetação}

As curvas de progresso da área foliar obtidas nas duas épocas encontram-se na Figura 10. Para época 2, notou-se que as curvas de ambos os 
tratamentos tiveram comportamento bastante semelhante. Essa tendência também foi observada para época 1 em avaliações até 49 dias após o plantio, momento em que as curvas tenderam a separar-se. Entretanto, para todas as avaliações, em ambos os experimentos, não se encontraram diferenças estatísticas entre o tratamento testemunha e o tratamento com aplicação semanal do fungicida.

A integral das áreas foliares, durante a estação de cultivo, foi utilizada para comparação das áreas sob as curvas de progresso da área foliar. Esses valores demonstraram, para ambos os ensaios, a inexistência de diferença significativa entre os tratamentos (Tabela 7).

Os valores observados para produção, gramas planta ${ }^{-1}$, encontram-se na Tabela 7. De maneira análoga aos resultados observados para área foliar, não se observou a existência de diferença estatística entre as produções para ambos os tratamentos nas duas épocas de plantio

Tabela 7 - Área sob a curva de progresso da área foliar, AULAPC, do feijoeiro e produção, $\mathrm{g}$ planta $^{-1}$, para dois experimentos realizados em casa de vegetação.

\begin{tabular}{lcccc}
\hline & \multicolumn{2}{c}{ Época 1 } & \multicolumn{2}{c}{ Época 2 } \\
\cline { 2 - 5 } Tratamento & AULAPC & Produção & AULAPC & Produção \\
\hline Com controle $^{2}$ & $83275 \mathrm{a}$ & $6,5 \mathrm{a}$ & $89130 \mathrm{a}$ & $13,4 \mathrm{a}$ \\
Testemunha & $88816 \mathrm{a}$ & $8,0 \mathrm{a}$ & $85050 \mathrm{a}$ & $13,2 \mathrm{a}$ \\
\hline C. variação (\%) & 42,3 & 49,0 & 19,7 & 29,7 \\
\hline
\end{tabular}

\footnotetext{
${ }^{T}$ Médias seguidas de mesma letra não diferem estatisticamente entre si (Tukey 0,05)

${ }^{2}$ Aplicação semanal de fungicida trifenil acetato de estanho $0,2 \mathrm{~kg} / \mathrm{ha}$
} 


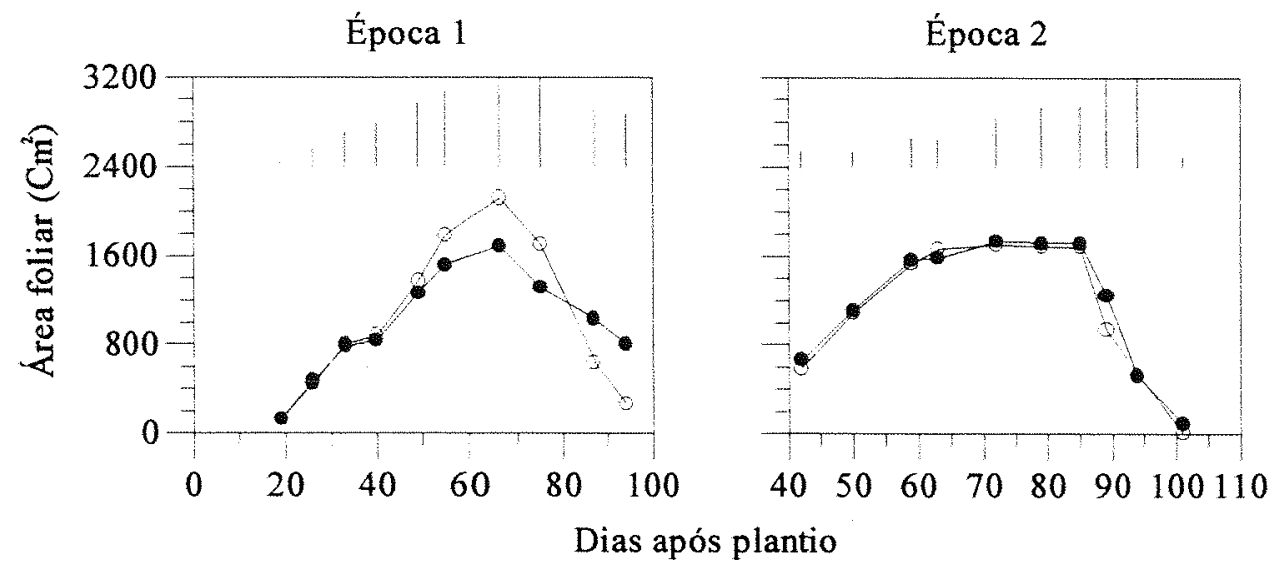

Figura 10 - Progresso da área foliar do feijoeiro em duas épocas de plantio. Círculos cheios representam o tratamento com aplicação semanal de fungicida. Círculos vazios representam o tratamento testemunha. As Barras verticais representam a diferença mínima significativa $(\mathrm{P}<0,05)$ para comparação dos tratamentos em cada avaliação. $\mathrm{O}$ início das pulverizações deu-se aos 20 e 37 dias após o plantio para as épocas 1 e 2 respectivamente.

Para os resultados de casa de vegetação não se realizou a análise dos dados por meio das variáveis derivadas da área foliar, HAD e HAA. Isto se deve ao fato da distribuição aleatória das plantas na casa de vegetação, o que não permitiu o cálculo do índice de área foliar, LAI, e também devido à não coleta de dados de irradiação, no período, dentro da casa de vegetação. 
No caso de controle de doenças com fungicidas estanhados, presume-se que tais produtos sejam responsáveis por um efeito tônico à cultura, resultando num verde bem mais intenso. Os resultados deste trabalho demonstram que o fungicida a nível de casa de vegetação, para a cultura do feijoeiro, não apresenta um efeito tônico marcante, ou seja, ele não é capaz de estimular o crescimento da planta e conseqüentemente produzir maior área foliar quando comparados ao tratamento testemunha. Deste modo, em situações de produção em que a antracnose estiver causando redução da área foliar sadia, o emprego desse fungicida será muito mais pronunciado em proteger as folhas sadias da infecção, do que, como se supunha, de estimular o crescimento foliar e conseqüentemente da planta.

\subsubsection{Experimentos de campo}

\subsubsection{Severidade de doença, desfolha e AUDPC}

As curvas de progresso para severidade de antracnose e desfolha observadas no feijoeiro em três experimentos encontram-se na Figura 11.

Em todos os ensaios, observa-se que a severidade de doença, para todos os tratamentos, permanece muito baixa até cerca de 15 dias após a respectiva inoculação do campo, que na Figura 11, é registrada pela seta pontilhada. Para o campo 5 , a severidade de doença entre os tratamentos, foi muito semelhante até 55 dias após o plantio (DAP). A partir desse momento, observa-se que, para o tratamento 1,0 progresso da doença dá-se numa intensidade bem menor. Essa diferença é estatisticamente significativa, Tukey $(P<0,05)$, nas avaliações situadas entre 69 e 97 DAP. Nessas avaliações, o tratamento 1 foi superior aos demais, que apresentaram

resultados estatisticamente semelhantes. Para o campo 6, observou-se o mesmo comportamento, ou seja, severidades semelhantes até $54 \mathrm{DAP}$, e menores severidades 
para o tratamento 1 nas avaliações compreendidas entre 61 e 96 DAP. Entretanto, diferença estatisticamente significativa, só foi observada aos $73 \mathrm{DAP}$, quando o tratamento 1 foi superior a todos. Os tratamentos 3 e 4 não diferiram estatisticamente entre si, porém foram superiores em relação a testemunha. Os resultados do campo 7, apresentaram menor variabilidade entre as severidades observadas para os tratamentos. Não se observou nenhuma diferença estatística, entretanto, pela Figura 11, nota-se que o tratamento 1 apresentou uma menor severidade de doença entre 79 e 107 DAP.

A inexistência de diferença entre os tratamentos para o campo 7 , pode ser atribuída à menor severidade de doença, quando comparada aos demais campos. Note que, para o campo 7, a severidade máxima foi aproximadamente a metade da obtida para os campos 5 e 6 . Nestes ensaios, quando a severidade situava-se nos níveis observados para o campo 7, também não ocorria diferença entre os tratamentos.

Os resultados para desfolha (Figura 11) apresentaram a mesma tendência da observada para severidade de doença. Para o campo 5, o tratamento 1, foi estatisticamente superior aos demais nas avaliações entre 76 a 97 DAP. No campo 6, esta superioridade foi observada entre 82 e 96 DAP. Para o campo 7, como observado para severidade, não ocorreu diferença estatística entre os tratamentos.

Os valores de área sob a curva de progresso da doença encontram-se na Tabela 8. Os resultados para os campos 6 e 7 revelaram a inexistência de diferença significativa entre os tratamentos. Para o campo 5, o tratamento 1 foi estatisticamente superior a todos os demais. Os tratamentos 2,3 e 4 não diferiram entre si. Os coeficientes de variação observados apresentaram valores baixos, para experimentos deste tipo, demonstrando, portanto, boa precisão do experimento (Gomes, 1987).

Os resultados de AUDPC podem ser utilizados para se avaliar a eficiência da medida de controle utilizada. Deste modo, eficiência do tratamento só pode ser observada para o campo 5 . Neste experimento, apenas a pulverização semanal do fungicida foi eficiente para controlar a doença. A não constatação da eficiência deste tratamento para os campo 6 e 7 pode ser atribuída aos baixos valores de AUDPC, 
indicando que altas severidades doença não predominaram durante todo o ciclo da cultura (Tabela 8 e Figura 11).

Os valores das taxas de progresso da doença não demonstraram nenhuma diferença significativa em nenhum dos experimentos. Os valores observados para as taxas de progresso de doença foram em média 0,15, 0,12 e 0,09 logito dia ${ }^{-1}$ para os campos 5, 6 e 7, respectivamente. Em especial, observando-se as taxas de progresso da doença para o campo 5, notou-se que, para o tratamento testemunha, a taxa foi de 0,19 logito dia ${ }^{-1}$, enquanto que, para o tratamento 1 , ela foi de 0,11 logito dia $^{-1}$. Essa diferença, embora não significativa, foi responsável pela diferenças de severidades observadas nos respectivos tratamentos, resultando em curvas de progresso da doença bem distintas (Figura 11).

Tabela 8 - Área sob a curva de progresso da doença, AUDPC, para antracnose do feijoeiro, para três experimentos realizados em condições de campo. Tratamento 1 - pulverizações semanais iniciadas 7 dias após a inoculação. Tratamento 2 - pulverizações no estádio $R_{5}$ (Michaels, 1994) e 14 dias após. Tratamento 3 - pulverização no estádio $R_{5}$. Tratamento 4 testemunha.

\begin{tabular}{|c|c|c|c|}
\hline \multirow[b]{2}{*}{ Tratamento } & \multicolumn{3}{|c|}{ AUDPC $^{1}$} \\
\hline & Campo 5 & Campo 6 & Campo 7 \\
\hline 1 & $2034 a$ & $793 \mathrm{a}$ & $507 \mathrm{a}$ \\
\hline 2 & $3499 \mathrm{~b}$ & $1574 \mathrm{a}$ & $803 \mathrm{a}$ \\
\hline 3 & $3502 \mathrm{~b}$ & $1627 \mathrm{a}$ & $810 \mathrm{a}$ \\
\hline 4 & $3922 \mathrm{~b}$ & $1692 \mathrm{a}$ & $818 \mathrm{a}$ \\
\hline C de Variação (\%) & 13,1 & 29,8 & 31,9 \\
\hline
\end{tabular}

${ }^{\top}$ Médias seguidas de mesma letra não diferem estatisticamente entre si (Tukey 0,05 ) 
Tratamento $1 \rightarrow$ Tratamento $2 \rightarrow$ Tratamento $3-$ Tratamento 4

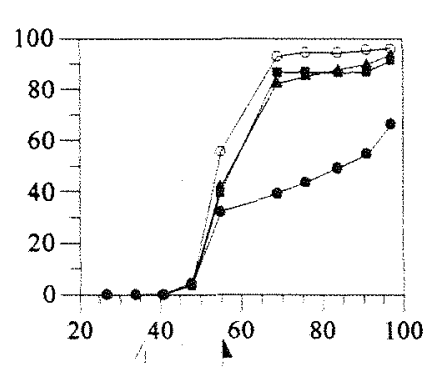

Campo 5
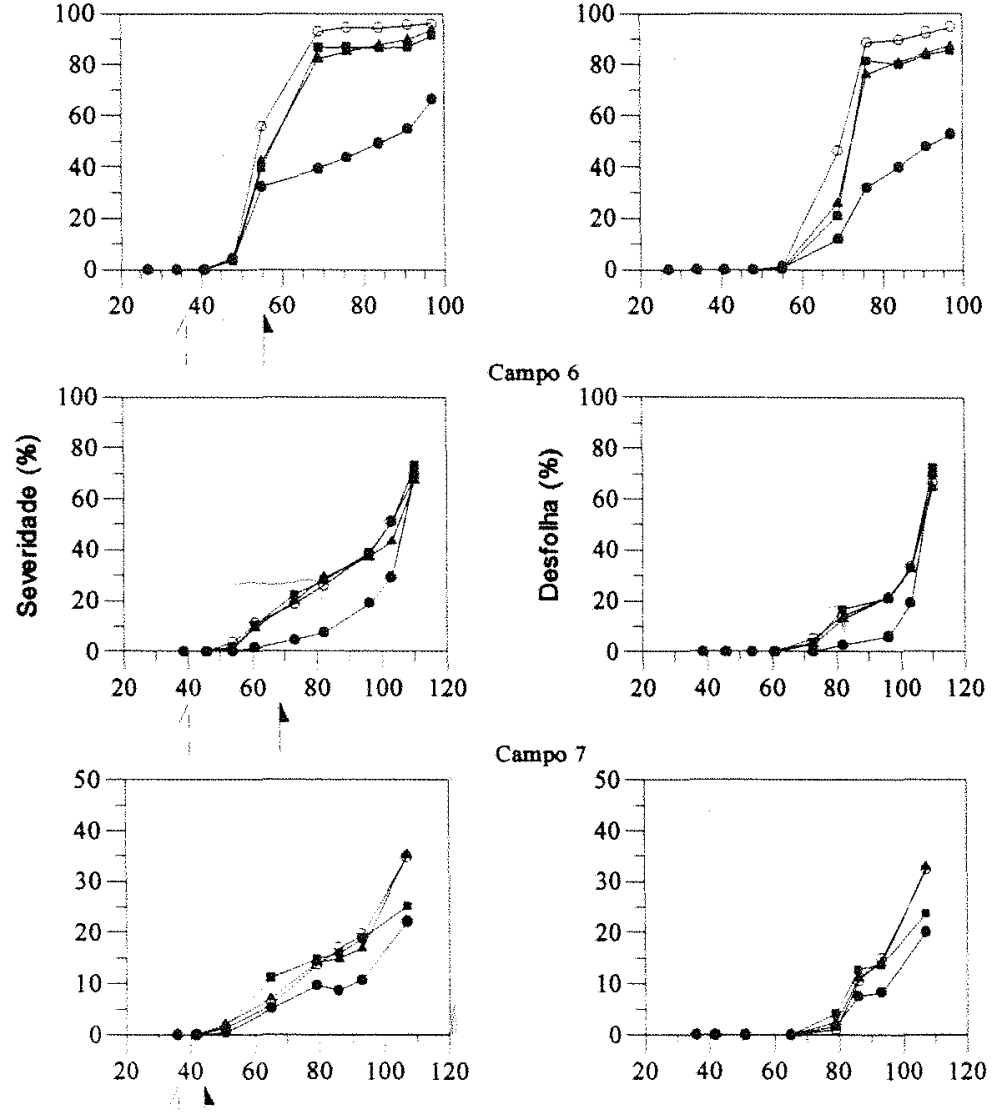

Campo 7

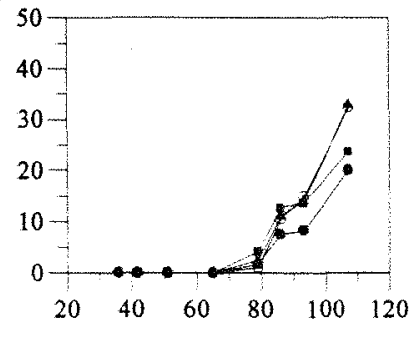

Dias após o plantio

Figura 11 - Curva de progresso da severidade de doença e desfolha promovida pela antracnose do feijoeiro, para os campos 5, 6 e 7. As setas pontilhadas representam a época de inoculação do campo. As setas cheias representam o estádio de crescimento $R_{5}$ (Michaels, 1994). Tratamento 1 pulverizações semanais iniciadas 7 dias após a inoculação. Tratamento 2 pulverizações no estádio $R_{5}$ e 14 dias após. Tratamento 3 - pulverização no estádio $\mathrm{R}_{5}$. Tratamento 4 - testemunha. 


\subsubsection{LAI, HLAI e HRI}

Os valores do índice de área foliar, LAI e índice de área foliar sadia, HLAI encontram-se na Figura 12.

Os valores de LAl, para os campos 5, 6 e 7 não demonstraram nenhuma diferença estatisticamente significativa em nenhuma das avaliações. Na Figura 12, pode-se observar que as curvas obtidas por esses valores são bastante semelhantes. A inexistência de diferença entre os tratamentos pode ser facilmente compreendida. Nesses experimentos, o único fator capaz de promover diferença entre os LAI, é a severidade de doença. Neste caso, a severidade de doença e desfolha foi computada para o cálculo do LAI, o que impossibilita a verificação do efeito da doença sobre as plantas.

A ineficiência do LAI, para observação de diferenças entre tratamentos, pode ser suplantada com a utilização do HLAI. As curvas apresentadas na Figura 12 demonstram que até aos 55 e 61 dias após o plantio, DAP, para os campos 5 e 6 , respectivamente, praticamente não houve diferença entre os tratamentos. A partir dessa avaliação, começa a ser observada uma separação do tratamento 1 em relação aos demais. A análise estatística demonstrou que, para o campo 5, entre 69 e 97 DAP, o tratamento 1 apresentou valores de HLAI superiores ao de todos os outros tratamentos $(\mathrm{P}<0,05)$. $\mathrm{O}$ tratamento 2 , nessas avaliações, manteve-se diferente e superior em relação aos tratamentos 3 e 4 , os quais não diferiram estatisticamente entre si. Para o campo 6, entre 61 e $82 \mathrm{DAP}$, semelhantemente ao observado para o campo 5 , o tratamento 1 destacou-se com maiores valores de HLAI. Entretanto, a tendência observada para o tratamento 2 no campo 5 não se repetiu neste ensaio. Os demais tratamentos foram estatisticamente semelhantes. Para o campo 7 não foi observada diferença estatística em nenhuma avaliação.

Ao se observarem as Figuras 11 e 12 conjuntamente, pode-se notar que o momento no qual ocorre maior progresso nas severidades de doença e desfolha, 
coincide com a época na qual se inicia a diferenciação dos valores de HLAI. Isto indica que o principal fator para variabilidade de HLAI foi a antracnose.

Os valores de HRI são diretamente proporcionais a HLAI. Deste modo, esperava-se o mesmo comportamento observado para HLAI. Para o campo 5 tal comportamento foi verificado entre 69 e 97 DAP (Figura 13). Maiores valores de HRI foram observados para o tratamento 1 , enquanto o tratamento 2 proporcionou valores intermediários entre o tratamento 1 e o tratamento 3 e 4, os quais não diferiram entre si. Para o campo 6, entre 61 e 73 DAP, de modo semelhante ao observado para HLAI, maiores valores de HRI foram observados para o tratamento 1 . No campo 7, para HRI, também não foi observada diferença estatística em nenhuma avaliação.

Os valores de HLAI e HRI demonstraram que sucesso no controle da antracnose só foi obtido pelo tratamento 1 . Neste tratamento, as pulverizações foram iniciadas 7 dias após a inoculação do patógeno nos campos, seta pontilhada nas Figuras 11, 12 e 13. Como já citado, constatou-se que a severidade de doença, em ambos os experimentos, começou a manifestar-se 15 dias após a inoculação. A partir desse momento observou-se que a severidade apresentada pelo tratamento 1 teve menor taxa de progresso de doença, embora não tenha sido estatisticamente significativo. Deste modo, o menor incremento de doença observado no tratamento 1 deve ser atribuído à eficiência do fungicida em controlar a doença. Paralelamente, pode-se observar que as menores severidades de doença resultaram em maiores HLAI. Consequentemente, os maiores valores do HLAI foram proporcionados pelo emprego do fungicida. Isto resultou numa recuperação de $\mathrm{HLAI}$ nitidamente observado para o campo 5 a partir dos 55 DAP. Esta recuperação de HLAI só pode ser observada devido à severa infecção obtida no campo 5, que resultou em folhas totalmente necrosadas. O emprego do fungicida não demonstrou efeito curativo de folhas; entretanto, seu efeito foi mais pronunciado na proteção das folhas novas que brotavam. Nos tratamentos 2 e 3 , as pulverizações não foram suficientes para uma eficiente proteção das brotações. Deste modo, a disseminação do patógeno entre as folhas, promovida pela água de irrigação e/ou de chuva, possibilitou um rápido progresso da doença. Para o campo 6, o HLAI 
dos tratamentos 2, 3 e 4 apresentaram menores velocidades de incremento em relação ao tratamento 1. Isto indica que apenas para o tratamento 1 , a freqüência de pulverizações promoveu proteção eficiente das plantas.

\subsubsection{HAD, HAA e produção}

Os resultados de duração da área foliar sadia (HAD), absorção da área foliar sadia (HAA) e produção, podem ser encontrados na Figura 14.

Os valores de $\mathrm{HAD}$ para o campo 5 apresentaram-se diferentes estatisticamente. O maior valor, estatisticamente superior, foi observado para o tratamento 1 . Os tratamentos 2 e 3 apresentaram-se intermediários, e estatisticamente iguais entre si. Os menores valores de $\mathrm{HAD}$ foram observados para o tratamento 4 . Para o campo 6, o mesmo comportamento foi obtido pelo tratamento 1. Entretanto, os tratamentos 2 e 3 tiveram valores de $\mathrm{HAD}$ iguais estatisticamente e inferiores ao tratamento testemunha. Este comportamento pode ser justificado pelos maiores valores de HLAI observados para o tratamento 4 em avaliações realizadas entre 73 e 96 DAP. Para o campo 7 não se encontraram diferenças entre os valores de HAD para os tratamentos realizados. Esses resultados advêm da semelhança entre os valores de HLAI observados.

Os valores de HAA, para o campo 5, indicaram o tratamento 1 ser estatisticamente superior aos demais. $\mathrm{O}$ tratamento 2 apresentou-se como o segundo colocado e os tratamentos 3 e 4 iguais entre si e inferiores estatisticamente aos outros tratamentos. Para o campo 6 e 7 não se observou diferença estatística entre os tratamentos. Para o campo 7 este resultado já era esperado perante os resultados prévios de HAD; entretanto, para o campo 6, a inexistência de diferenças pode ser justificada pela pequena diferença observada para os valores de $\mathrm{HAD}$. 
Tratamento $1-$ Tratamento $2 \rightarrow$ Tratamento $3-5$ Tratamento 4

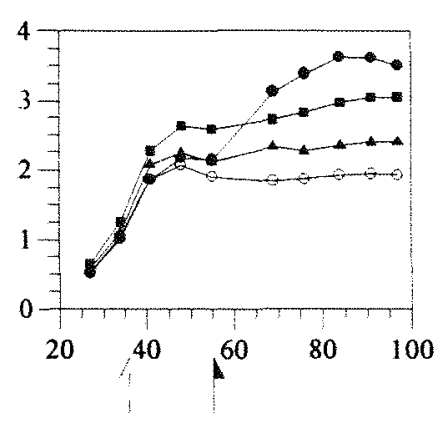

Campo 5
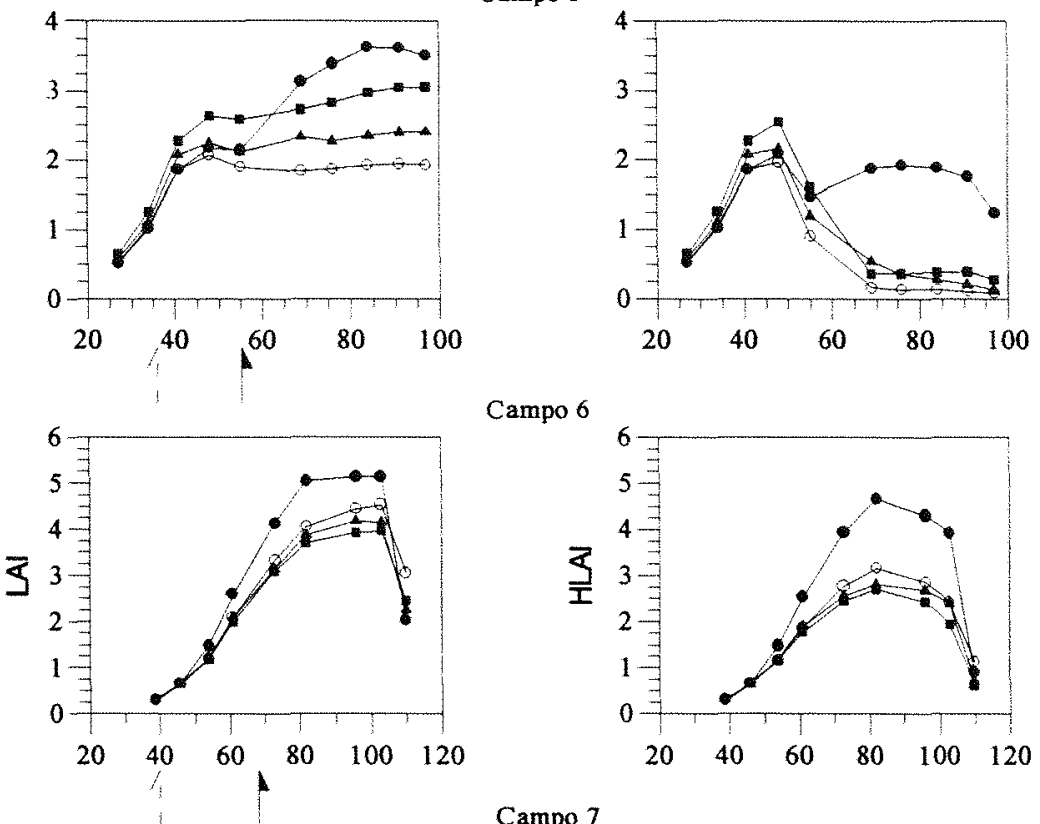

Campo 6

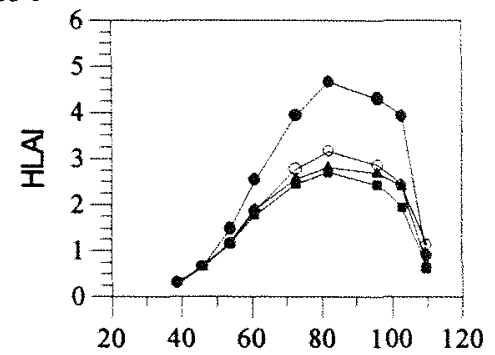

Campo 7
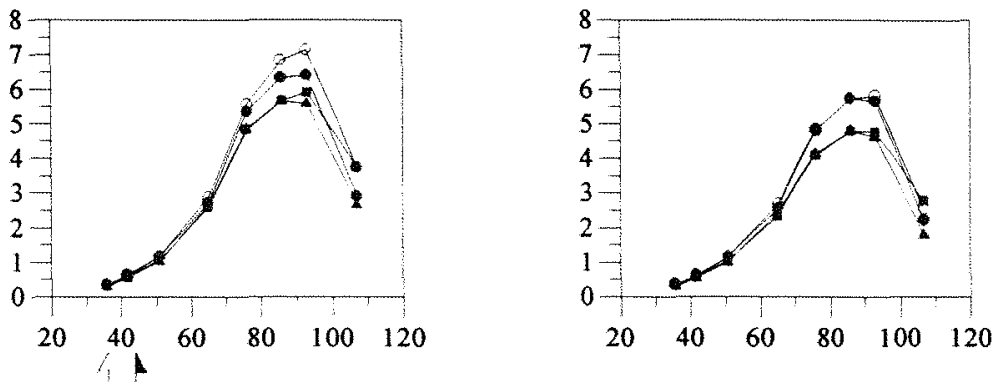

Dias após o plantio

Figura 12 - Índice de área foliar (LAI), e índice de área foliar sadio (HLAI), para os campos 5,6 e 7 . As setas pontilhadas representam a época de inoculação do campo. As setas cheias representam o estádio de crescimento $R_{5}$ (Michaels, 1994). Tratamento 1 - pulverizações semanais iniciadas 7 dias após a inoculação. Tratamento 2 - pulverizações no estádio $R_{5}$ e 14 dias após. Tratamento 3 - pulverização no estádio $R_{5}$. Tratamento 4 - testemunha. 

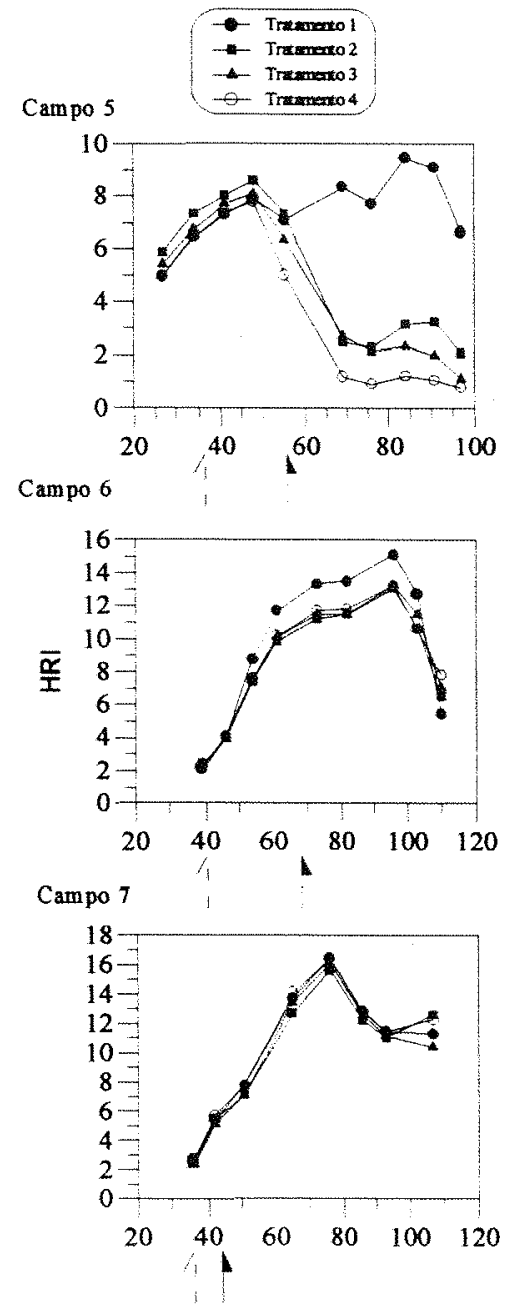

Dias após o plantio

Figura 13 - Radiação interceptada pela área foliar sadia por unidade de tempo, do feijoeiro, para os campos 5, 6 e 7. As setas pontilhadas representam a época de inoculação do campo. As setas cheias representam o estádio de crescimento $R_{5}$ (Michaels, 1994). Tratamento 1 - pulverizações semanais iniciadas 7 dias após a inoculação. Tratamento 2 - pulverizações no estádio $\mathrm{R}_{5}$ e 14 dias após. Tratamento 3 - pulverização no estádio $\mathrm{R}_{5}$. Tratamento 4 - testemunha. 

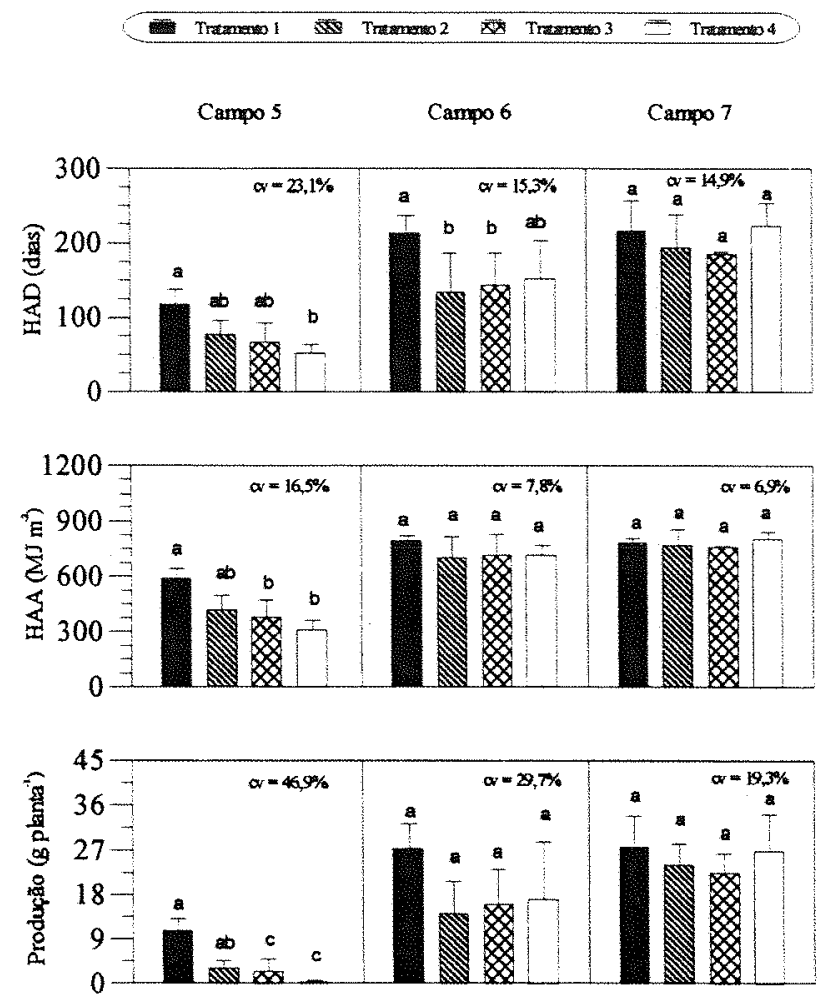

Figura 14 - Duração da área foliar sadia, HAD (dias), absorção da área foliar sadia, HAA ( $\mathrm{MJ} \mathrm{m}^{-2}$ ) e produção (g planta $\left.{ }^{-1}\right)$ para os campos 5,6 e 7 do patossistema feijão antracnose. Tratamento 1 - pulverizações semanais iniciadas 7 dias após a inoculação. Tratamento 2 - pulverizações no estádio $R_{5}$ e 14 dias após. Tratamento 3 - pulverização no estádio $R_{5}$. Tratamento 4 - testemunha. Barras representam o erro padrão da amostra. Barras seguidas de mesma letra não diferem estatisticamente entre si (Tukey, $\mathrm{P}<0,05$ ). 
Os valores de produção apresentaram a mesma tendência observada para HAA. Nos campos 6 e 7 não houve diferença estatística entre os tratamentos. Já para o campo 5 , produtividade superior foi promovida pelo tratamento 1 . O tratamento 2 , embora inferior ao tratamento 1 , demonstrou superioridade estatística em relação aos tratamentos 3 e 4, os quais não diferiram entre si. As produções observadas, nesse experimento, para os tratamentos $1,2,3$, e 4 foram $2568,696,552$ e $36 \mathrm{~kg} / \mathrm{ha}$, respectivamente. Estes valores, para os campos 6 e 7, foram em média 4470 e 6072 $\mathrm{kg} / \mathrm{ha}$. Essas produções foram muito altas e não são freqüentes a nível de produtores.

Os resultados de HAD, HAA e produção apresentados na Figura 14, apresentam nítida relação das variáveis derivadas da área foliar com produção. Para o campo 5, tal relação é muito nítida. Note que os maiores valores de HAD estiveram expostos aos mesmos valores de radiação, o que resultou em maiores valores de HAA. Essa maior radiação absorvida, resultou em produção maior. Esses resultados estão de acordo com as proposições originais de Watson (1947) e Waggoner \& Berger (1987).

\subsubsection{Limiar de dano econômico}

O manejo integrado de doenças do feijoeiro pretende implementar um sistema de controle baseado num limiar de dano econômico, LDE. Bergamin Filho et al. (1997) estimaram um limiar de dano para o patossistema feijão/mancha angular. Utilizando-se de mesma metodologia, pode-se deduzir que para o caso da antracnose, tal limiar se dá quando ocorre a diferença da absorção da radiação pela área foliar sadia entre a parcela controle e o situação de produção (Lopes et al., 1994) for de 1/4 de HRI.

Passou-se a analisar a parcela controle, tratamento 1, comparada ao tratamento testemunha, para os três experimentos realizados. Na Figura 15 encontramse os valores de HRI para os dois tratamentos. As setas cheias representam a época de início das pulverizações na parcela controle. Vale a pena lembrar que parcela controle é definida como uma situação de produção na qual a cultura é mantida livre de doença. 

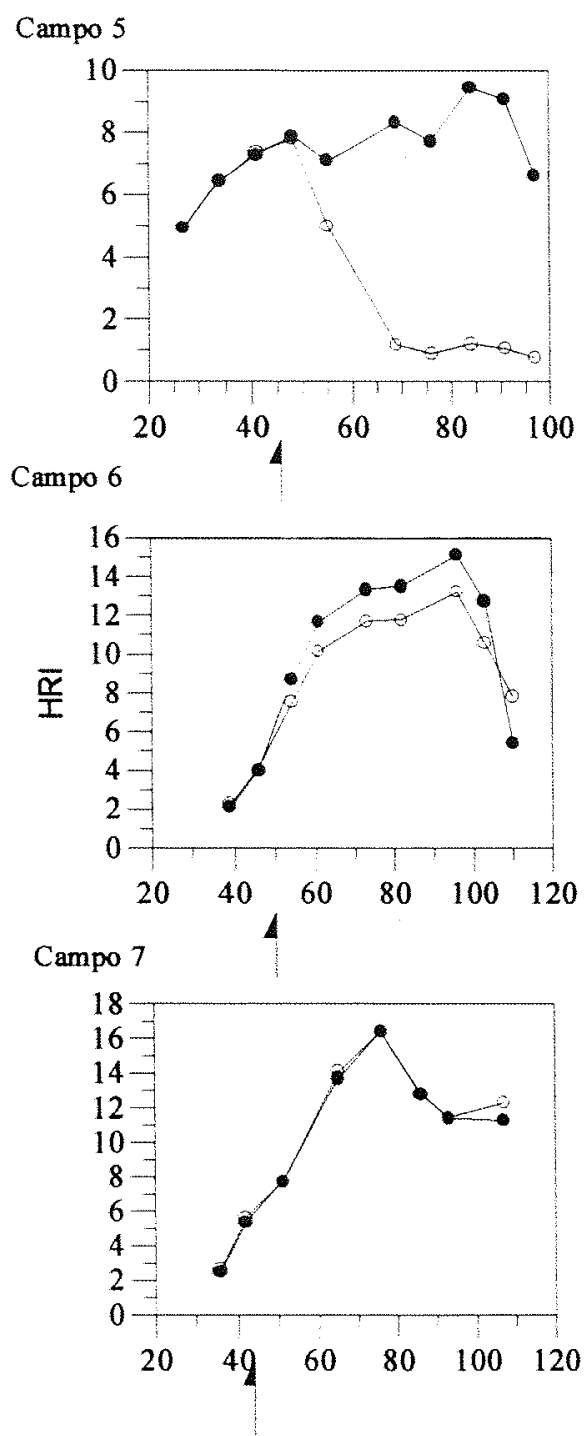

Dias após o plantio

Figura 15 - Radiação interceptada pela área foliar sadia por unidade de tempo, do feijoeiro, para os campos 5, 6 e 7. As setas cheias representam o estádio de crescimento $R_{5}$ (Michaels, 1994). Círculos cheios representam o tratamento 1, parcela controle. Círculos vazios representam o tratamento 4, testemunha. 
Nesses experimentos não se conseguiu manter a cultura livre de doença devido à inoculação prévia do patógeno aos 36,39 e 37 dias após o plantio para o campo 5,6 e 7, respectivamente. $O$ início das pulverizações na parcela controle deu-se aos 43, 46 e 44 DAP, para os campos 5, 6 e 7, respectivamente. Procedeu-se desta maneira, para simular uma condição de campo, aonde, geralmente, o patógeno chega antes do início da aplicação das medidas de controle. O fungicida utilizado demonstrou efeito protetor e não curativo, o que permitiu a ocorrência de severidades de doença em todos os tratamentos, inclusive na parcela controle.

A variação de $H R I, \Delta H R I=H R I$ Parcela controle $-H R I$ testemunha, para o campo 5, aos $48 \mathrm{DAP}$ era de 0,12 HRI. Aos $55 \mathrm{DAP}, \triangle \mathrm{HRI}$ era de 2,1 HRI. Isto demonstra que o LDE para esta situação de produção, foi alcançado entre as avaliações dos 48 e 55 DAP. Para o campo 6, o $\triangle \mathrm{HRI}$ aos $46 \mathrm{DAP}$ era de $-0,11 \mathrm{HRI}$, ao passo que aos $54 \mathrm{DAP}$ esta diferença era de 1,22 HRI. Semelhantemente ao descrito para o campo 5 , no campo 6, o LDE foi atingido entre as avaliações realizadas aos 46 e 54 . Por outro lado, as menores severidades de doença observadas para o campo 7 , resultaram em valores de HRI semelhantes para a parcela controle e a testemunha, não permitindo que o LDE fosse atingido (Figura 15).

Vale a pena ressaltar que a época na qual o LDE foi alcançado, nos campos 5 e 6, situa-se entre os estádios de crescimento de $V_{4}$ e $R_{5}$ (Michaels, 1994). Nessa época, a ausência de uma medida de controle eficiente pode resultar em severos danos à produção. Tal fato pode ser verificado observando a Figura 14, na qual o tratamento 2 apresenta diminuição na produção em relação a parcela controle.

Na Figura 13, pode-se observar o comportamento de HRI para o campo 5. Como já discutido acima, verificou-se que o LDE foi atingido entre 48 e 55 DAP. Note-se que neste experimento o tratamento 2 teve uma de suas pulverizações realizada no estádio de $R_{5}$. As medidas de controle empregadas nesse tratamento podem não ter sido suficientes para controlar o patógeno, e/ou elas podem ter sido implementadas muito depois do LDE ter sido atingido, o que explica os danos citados acima. A mesma 
tendência foi observada para o tratamento 2 , realizado no campo 6. Para o tratamento 3 a situação piora, pois neste tratamento a medida de controle foi implementada somente 14 dias após o estádio $R_{5}$. Deste modo, acredita-se que tal implementação tenha ocorrido muito tarde, tanto quando se considera a época na qual o LDE foi atingido, como quando se verifica qual o estádio de crescimento da cultura quando da aplicação do fungicida.

Note-se que no campo 5, para o tratamento 1 , entre 48 e $55 \mathrm{DAP}$, a curva de HRI apresenta uma abrupta queda. Nessa época, ao se observar as Figuras 11 e 12, constata-se uma rápida elevação na severidade de doença e conseqüentemente uma queda em HLAI. Entretanto, após 55 DAP, a proteção do fungicida proporcionado às folhas novas que começavam a brotar permitiu uma reação da planta verificada pela recuperação dos valores de HLAI e conseqüentemente de HRI observados. Isto indica que a implementação de uma medida de controle eficiente na época na qual o LDE for atingido, para o patossistema feijão/antracnose, apresenta enorme potencial de resposta, o que viabiliza o manejo integrado de doenças na cultura.

A antracnose é tida como uma das mais importantes doenças do feijoeiro. Na ausência de medidas de controle do patógeno, ele é capaz de causar os danos de maior intensidade na cultura (Rava et al., 1998; Sartorato, 1998).

Neste trabalho, verificou-se que o emprego do fungicida trifenil acetato de estanho em casa de vegetação, na ausência de doença, não proporcionou nenhum efeito tônico à cultura. Com este ensaio pode-se inferir que o efeito do fungicida sobre as plantas dá-se na proteção das folhas à infecção. A nível de campo verificou-se que as parcelas que receberam maior intensidade de aplicação do fungicida não apresentaram área foliar estatisticamente superior em relação à testemunha. Isto pode ser verificado pelo LAI. Esses resultados diferem dos obtidos por Jesus Jr. et al. (1997), os quais trabalhando com o patossistema feijão/mancha angular e o fungicida tiofanato metílico, observaram que maiores áreas foliares foram proporcionadas pela aplicação do fungicida. Esse efeito tônico pode ser atribuído a um efeito sistêmico desse fungicida, 
provavelmente, com algum efeito curativo sobre o patógeno. Outra hipótese que pode ser cogitada é algum estímulo na fotossíntese da planta tratada.

A severidade de doença pode ser reduzida pelo emprego do fungicida. Isto resultou em menores danos nas parcelas que receberam o tratamento 1. Uma importante constatação foi a observação de que após o início das pulverizações nas parcelas que receberam o tratamento 1 , a taxa de progresso da doença foi bastante reduzida.

As diferenças nas taxas de progresso da doença, embora não significativas estatisticamente, possibilitaram a obtenção de diferenças em HLAI e HRI. Por meio dos valores de HLAI e HRI, para cada tratamento, verificou-se que os valores de HAD e HAA apresentavam algumas diferenças. Isto permitiu revalidar os conceitos de Waggoner \& Berger (1987), pois maiores valores de HLAI, HRI, e conseqüentemente $\mathrm{HAD}$ e HAA, sempre estiveram associados a maiores produtividades. Entretanto, mais importante do que a verificação dessa associação, foi a constatação de que os valores instantâneos de HLAI e HRI podem sofrer incrementos, após uma fase de queda. Essa recuperação indica que a planta está reagindo ao progresso da doença. Neste caso, como não se verificou efeito curativo do fungicida, essa recuperação da planta deveu-se à emissão de folhas novas, que foram protegidas pelo fungicida. Essas folhas é que foram responsáveis pelos maiores valores de HLAI e HRI, que resultaram na redução de danos nas parcelas tratadas.

O limiar de dano econômico estabelecido para o patossistema feijão/antracnose foi atingido nos experimentos. As medidas de controle propostas neste trabalho infelizmente não se baseavam no LDE e sim nas observações de melhores épocas sugeridas por Jesus Jr. et al. (1997). Deste modo, a recuperação de área foliar sadia discutida acima, não pode ser observada pelo emprego de medida de controle que fosse aplicada imediatamente após o LDE ser atingido.

Esses resultados permitem concluir que a implementação de um sistema de manejo integrado de doenças, neste caso, baseado no LDE, parece ser bastante viável para a cultura do feijoeiro. Resta, pois, a validação do modelo proposto, 
realizando-se ensaios, a nível de campo, em diferentes locais, tendo as propostas de controle baseadas no LDE e em eficientes fungicidas para o controle da doença. 


\section{CONCLUSÕES}

De acordo com os objetivos propostos e a análise dos resultados obtidos chegou-se às seguintes conclusões:

- A área sob a curva de progresso da antracnose, obtida com os valores de severidade de doença, não apresentou boa correlação com os componentes de produção do feijoeiro.

- A desfolha promovida pela antracnose, quando incorporada às funções de dano, permitiu melhores relações com os componentes de produção do feijoeiro.

- As variáveis relacionadas à área foliar sadia do feijoeiro, como a duração da área foliar sadia (HAD), e a absorção da área foliar sadia (HAA), apresentaram boas correlações com os componentes de produção do feijoeiro.

- A correlação entre HAA e produção foi consistente em diferentes épocas de plantio indicando a possibilidade de uso dessa variável em sistemas de manejo integrado da antracnose.

- Estipulou-se o $\triangle H R I$ entre a parcela controle e a situação de produção em $1 / 4$ de HRI, como o limiar de dano econômico da cultura.

- Não houve um comprimento de onda ou índice vegetativo para as medidas de refletância, as quais apresentaram boa relação com a severidade da doença ou desfolha a nível de campo 
- As melhores relações com o índice de área foliar sadia e absorção da área foliar sadia foram obtidas com medidas de refletância na faixa de 760 e $810 \mathrm{~nm}$ e com a diferença normalizada que usa os comprimentos de onda de $810 \mathrm{~nm}$ e $660 \mathrm{~nm}$.

- As medidas de refletância podem ser utilizadas em modelos para estimativa de HLAI que, juntamente com os dados de radiação, podem ser utilizados para cálculo de HRI e, conseqüentemente, utilização em sistemas de manejo integrado da antracnose.

- O fungicida trifenil acetato de estanho, quando empregado em épocas corretas, é eficiente para controle da antracnose, reduzindo a severidade de doença e conseqüentemente a área sob a curva de progresso da antracnose.

- O feijoeiro é capaz de responder a tratamentos com fungicidas, recuperando o índice de área foliar sadia (HLAI) e a absorção da área foliar sadia por unidade de tempo (HRI).

- O sistema de manejo integrado da antracnose do feijoeiro, baseado em um limiar de dano econômico, é bastante viável. 


\section{REFERÊNCIAS BIBLIOGRÁFICAS}

AASE, J.K.; SIDDOWAY, F.H. Determining winter wheat stand densities using spectral reflectance measurements. Agronomy Journal, v.72, p.149-152, 1980.

ADROYAN, M.L.; FANTINI, G.S.; DE VICENZO, M.C.V. Avaliação da eficiência do fungicida Azoxystrobin no controle da antracnose (Colletotrichum lindemuthianum) ocorrente na cultura do feijão (Phaseolus vulgaris). In: CONGRESSO BRASILEIRO DE FITOPATOLOGIA, 29., Campo Grande, 1996. Fitopatologia Brasileira; resumos. Brasilia: SBF, 1996. p.354.

ALZATE-MARIN, A.L.; BAÍA, G.S.; FALEIRO, F.G.; CARVALHO, G.A.; PAULA Jr., T.L.; MOREIRA, M.A.; BARROS, E.G. Diversidade genética de raças de Colletotrichum lindemuthianum que ocorrem no Brasil. In: CONGRESSO BRASILEIRO DE FITOPATOLOGIA, 28., Ilhéus, 1995. Fitopatologia Brasileira; resumos. Brasilia: SBF, 1995. p.356.

AMORIM, L.; BERGAMIN FILHO, A. Avaliação de doenças com utilização de escalas diagramáticas. Summa Phytopathologica, v.17, n.1, p.57-67, 1991.

AQUINO, V.M.; SHOKES, F.M.; BERGER, R.D.; GORBET, D.W.; KUCHARAK, T.A. Relationships among late leafspot, healthy leaf area duration, canopy reflectance, and pod yield of peanut. Phytopathology, v.82, p.546-552, 1992. 
ASRAR, G.; FUCHS, M.; KANEMASU, E.T.; HATFIELD, J.L. Estimating absorbed photosynthetic radiation and leaf area index from spectral reflectance in wheat. Agronomy Journal, v.76, p.300-306, 1984.

AYERS, J.E.; NELSON, R.R.; CASTOR, L.L.; BLANCO, M.H. Yield losses in corn caused by Helminthosporium maydis race T. Plant Disease Reporter, v.60, p.331-335, 1976.

BANNEROT, H. Résultats de I'infection d'une collection de haricots par six races physiologiques d'anthracnose. Annales de I'Amelioration des Plantes, v.15, p.201-222, 1965.

BASSANEZI, R.B. Interações entre o mosaico-em-desenho do feijoeiro e duas doenças fúngicas, ferrugem e mancha angular, em plantas de feijoeiro. Piracicaba, 1995. 122p. Dissertação (Mestrado) - Escola Superior de Agricultura "Luiz de Queiroz", Universidade de São Paulo.

BASSANEZI, R.B.; MARTINS, M.C.; GODOY, C.V.; AMORIM, L.; BERGAMIN FILHO, A. Efeito da antracnose na eficiência fotossintética do feijoeiro. Fitopatologia Brasileira, v.22, p.520-524, 1997.

BENHAMON, N.; LAFITTE, L.; BARTHE, J.P.; ESQUERRÉ-TUGAYÉ, M-T. Cell surface interactions between bean leaf cells and Colletotrichum lindemuthianum. Plant Physiology, v.97, p.234-244, 1991.

BERGAMIN FILHO, A. Avaliação de danos e perdas. In: BERGAMIN FILHO, A.; KIMATI, H.; AMORIM, L. (Ed.). Manual de fitopatologia: princípios e conceitos. 3. ed. São Paulo: Agronômica Ceres, 1995. v.1, cap. 33, p. 372-690.

BERGAMIN FILHO, A.; AMORIM, L. Doenças de plantas tropicais: epidemiologia e controle. São Paulo: Agronômica Ceres, 1996. 299p. 
BERGAMIN FILHO, A.; LOPES, D.B.; AMORIM, L.; GODOY, C.V.; BERGER, R.D. Avaliação de danos causados por doenças de plantas. Revisão Anual de Patologia de Plantas. v.3, p. 133-184, 1995.

BERGAMIN FILHO, A.; CARNEIRO, S.M.T.P.G.; GODOY, C.V.; AMORIM, L.; BERGER, R.D.; HAU, B. Angular leaf spot of Phaseolus beans: Relationships between disease, healthy leaf area, and yield. Phytopathology, v.87, n.5, p.506$515,1997$.

BIANCHINI, A.; MENEZES, J.R.; MARINGONI, A.C. Doenças e seu controle. In: INSTITUTO AGRONÔMICO DO PARANÁ. O feijão no Paraná. Londrina, 1989. p. 189-216. (IAPAR. Circular, 63).

BIANCHINI, A.; MOHAN, S.K.; MENEZES, J.R. Avaliação de fungicidas no controle da antracnose do feijoeiro causada por Colletotrichum lindemuthianum (Sacc. et Magn.) Br. \& Cav. Summa Phytopatologica, v.4, p.22, 1978.

BOOTE, K.J.; JONES, J.W.; MISHOE, J.W.; BERGER, R.D. Coupling pests to crop growth simulators to predict yield reductions. Phytopathology, v.73, p.1581$1587,1983$.

BOURGEOIS, G.; BOOTE, K. J. Leaflet and canopy photosynthesis of peanut affected by late leafspot. Agronomy Journal, v.84, p.359-366, 1992.

BROSCIOUS, S.C.; PATAKY, J.K.; KIRBY, H.W. Quantitative relationships between yield and foliar diseases of alfafa. Phytopathology, v.77, p.887-892, 1987.

CAMPBELL, C.L.; MADDEN, L.V. Introduction to plant disease epidemiology. New York: John Wiley, 1990, 532p. 
CANTERI, M.G. Uso de medidas de área foliar e refletância no manejo da mancha angular do feijoeiro. Piracicaba, 1988. 83p. Tese (Doutorado) - Escola Superior de Agricultura "Luiz de Queiroz", Universidade de São Paulo.

CANTERI, M.G.; DALLA PRIA, M.; SCHIEBELBEIN, L.M.; SILVA, O.C.; AMORIM, L.; BERGAMIN FILHO, A. Relações entre área foliar sadia, produtividade, refletância e severidade da mancha angular do feijoeiro. Fitopatologia Brasileira, v. 23, n. 4, p.498-501, 1998.

CANTERI, M.G.; GIGLIOTI, E.A. Software para seleção e treinamento de avaliadores de severidade de doenças em cana de açúcar. Publicatio UEPG Ciências Exatas e da Terra, v.2, p.57-69, 1996.

CARNEIRO, S.M.T.P.G. Quantificação de danos causados por Phaeoisariopsis griseola em feijoeiro (Phaseolus vulgaris) no município de Londrina-PR. Piracicaba, 1995. 102p. Dissertação (Mestrado) - Escola Superior de Agricultura "Luiz de Queiroz", Universidade de São Paulo.

CARVER, T.L.W.; GRIFFITHS, E. Effects of barley mildew on green leaf area and grain yield in field and greenhouse experiments. Annals of Applied Biology, v.101, p. $561-572,1982$.

CENTRO INTERNACIONAL DE AGRICULTURA TROPICAL. La antracnosis del frijol y su control. Cali, 1981. 27p. (CIAT. Guia de Estudio. Série 04SB-06.08).

CHIARAPPA, L (Ed.). Crop loss assessment methods. Farnham Royal: CAB, 1971. $123 \mathrm{p}$.

CHIARAPPA, L. Possibility of supervised plant disease control in pest management systems. FAO Plant Protection Bulletin, v.22, p.65-68, 1974. 
COSTA, A.S. Investigações sobre moléstias do feijoeiro no Brasil. In: SIMPÓSIO BRASILEIRO DO FEIJÃO, 1., Campinas, 1971. Anais. Viçosa, UFV, 1972. p.305-311.

DE VINCENZO, M.C.V.; SILVA, M.S.F. da; ADORYAN, M.L.; DARIO, G.J.A. Avaliação da eficiência do fungicida hexaconazole + chlorothalonil no controle de antracnose (Colletotrichum lindemuthianum) ocorrente na cultura do feijão (Phaseolus vulgaris). In: CONGRESSO BRASILEIRO DE FITOPATOLOGIA, 28., Ilhéus, 1995. Fitopatologia Brasileira; resumos. Brasília: SBF, 1995. p.377.

ELLIS, M.A.; GALVEZ, G.E.; SINCLAIR, J.B. Effecto de tres fungicidas sobre la germinación de semilla infectada de frijol (Phaseolus vulgaris L.). Turrialba, v.26, p.399-402, 1976.

FAO. Report of the first session of the FAO panel of experts on integrated pest control. Roma, 1968. 19p. (FAO Meeting Report, PL/M/\&).

FERRANDINO, F.J.; ELMER, W.H. Reduction in tomato yield due to septoria leaf spot. Plant Disease, v.76, p.208-211, 1992.

FONILLOUX, G. Bean anthracnose; new genes of resistance. Annual Report of the Bean Improvement Cooperative, v.19, p.36-37, 1976.

GALLI, M.A.; PARADELA, A.L.; SALVOS, S.; LUIZ NETO, M. Avaliação da eficiência de fungicida sistêmico no controle das doenças antracnose, mancha angular e mancha de alternaria para cultura do feijoeiro. In: CONGRESSO BRASILEIRO DE FITOPATOLOGIA, 28., Ilhéus, 1995. Fitopatologia Brasileira; resumos. Brasília: SBF, 1995. p.291. 
GAUNT, R.E. Physiological basis of yield loss. In: STAKMAN COMMEMORATIVE SYMPOSIUM ON CROP LOSS ASSESSMENT, 7. St. Paul, 1981. Proceedings. St. Paul: University of Minnesota, 1981. p.98-111.

GAUNT, R.E. Measurement of disease and pathogens. In: TENG, P.S. Crop loss assessment and pest management. St. Paul, APS Press, 1987. cap. 2, p.6-18.

GAUNT, R. E. The relationship between plant disease severity and yield. Annual Review of Phytopathology, v.33, p.119-144, 1995.

GENCHEV, D.; MTRANOV, L. New sources of resistance to Colletotrichum lindemuthianum, race-alpha. Annual Report of the Bean Improvement Cooperative, v.26, p.8-9, 1983.

GIROTO, R. Evaluación de fungicidas en el control de la antracnosis y de la mancha angular en poroto. IDIA - Informativo de Investigaciones Agricolas, v.308, p.29-32, 1974.

GODOY, C.V. Avaliação de danos causados pela mancha angular do feijoeiro. Piracicaba, 1995. 72p. Dissertação (Mestrado) - Escola Superior de Agricultura "Luiz de Queiroz", Universidade de São Paulo.

GODOY, C.V.; CARNEIRO, S.M.T.P.G.; IAMAUTI, M.T.; DALLA PRIA, M.; AMORIM, L.; BERGAMIN FILHO, A.; BERGER, R.D. Diagrammatic scales for foliar diseases of beans: development and validation. Zeitschrift für Planzenkrankheiten und Planzenschutz, v.104, p.336-345, 1997.

GOMES, F.P. Curso de estatística experimental. 2. ed. Piracicaba: Nobel, 1987. $467 \mathrm{p}$.

GOTH, R.W.; ZAUMAYER, W.J. Reactions of bean varieties to four races of antracnose. Plant Disease Reporter, v.49, p.815-818, 1965. 
HALLARD, I,; TREBUCHET, G. Bean anthracnose in western Europe. Annual Report of the Bean Improvement Cooperative, v.19, p.44-46, 1976

HARLAN, J.C.; ROSENTHAL, W.D.; SMITH, D.H. Estimating defoliation of peanuts from spectral data. Peanut Science, v.5, p.10-12, 1978.

HATFIELD, D.L. Remote detection of crop stress: application to plant pathology. Phytopathology, v.80, p.37-39, 1990.

HUBBELING, N. New aspects of breeding for disease resistance in beans (Phaseolus vulgaris L.). Euphytica, v.6, p.111-141, 1957.

HUGHES, G.; KEATINGE, J.D.H.; SCOTT, S.P. Pigeon pea as a dry season crop in trinidad, west Indies. II. Interception and utilization of solar radiation. Tropical Agriculture, v.58, p.191-199, 1981.

IAMAUTI, M.T. Avaliação de danos causados por Uromyces appendiculatus no feijoeiro. Piracicaba, 1995. 81p. Tese (Doutorado) - Escola Superior de Agricultura "Luiz de Queiroz", Universidade de São Paulo.

ISSA, E.; ARRUDA, H.V. Contribuição para o controle da ferrugem e da antracnose do feijoeiro. Arquivos do Instituto Biológico, v.31, p.114-126, 1964.

JACKSON, R.D. Remote sensing of biotic and abiotic plant stress. Annual Review of Phytopathology, v.24, p.265-287, 1986.

JAMES, W.C. Assessment of plant disease and losses. Annual Review of Phytopathology, v.12, p.27-48, 1974.

JAMES, W.C.; TENG, P.S. The quantification of production constraints associated with plant diseases. In: COAKEY, T.H. (Ed.) Applied biology, New York: Academic Press, 1979. v.4, p. 201-267. 
JAMES, W.C.; SHIH, C.S.; HODGSON, W.A.; CALLBECK, L.C. The quantitative relationship between late bight of potato and loss in tuber yield. Phytopathology, v.62, p.92-96, 1972.

JENKYN, J.F. Effects of mildew (Erysiphe graminis) on green leaf area of zephyr spring barley. Annals of Applied Biology, v.82, p.484-488, 1976.

JESUS JR, W.; VALE, F.X.R.; ZAMBOLIM, L.; COSTA, L.C.; COELHO, R.R. Estratégias de controle químico da mancha angular (Phaeoisariopsis griseola) do feijoeiro em Viçosa - MG. In: CONGRESSO BRASILEIRO DE FITOPATOLOGIA, 30., Poços de Caldas, 1997. Fitopatologia Brasileira; resumos. Brasilia: SBF, 1997. p.271.

JOHNSON, K.B. Defoliation, disease and growth: A replay. Phytopathology, v.77, p.1495-1497, 1987.

KIMATI, H. Algumas raças fisiológicas de Colletotrichum lindemuthianum (Sacc. et Magn.) Br. \& Cav., 1888, que ocorrem no Estado de São Paulo. Piracicaba, 1966. 28p. Dissertação (Mestrado) - Escola Superior de Agricultura "Luiz de Queiroz", Universidade de São Paulo.

KRANZ, J. Measuring plant disease. In: KRANZ, J. ; ROTEM, J. Experimental techniques in plant disease epidemiology. Heidelberg: Springer, 1988. cap. 3, p.35-50.

KRANZ, J.; JÖRG, E. The synecological approach in plant disease epidemiology. Review of Tropical Plant Pathology, v.6, p.27-38, 1989.

KRANZ, J.; ROYLE, J. Perspectives in mathematical modeling of plant disease epidemics. In: SCOTT, P.R.; BAINBRIDGE, A. (Ed.) Plant disease epidemiology. Oxford: Blackwell, 1978. p.111-119. 
LAST, F.T. Analysis of the effects of Erysiphe graminis on the growth of barley. Annals of Botany, v.26, p.279-289, 1962.

LIM, L.G.; GAUNT, R.E. Leaf area as factor in disease assessment. Journal of Agricultural Science, v.97, p.481-483, 1981.

LIM, L. G.; GAUNT, R.E. The effect of powdery mildew (Erysiphe graminis f. sp. hordei) and leaf rust (Puccinia hordei) on spring barley in New Zeland. I. Epidemic development, green leaf area and yield. Plant Pathology, v.35, p.44-53, 1986.

LIM, S. M. Brown spot severity and yield reduction in soybean. Phytopathology, v.70, p.974-977, 1980.

LOPES, D.B.; BERGER, R.D.; BERGAMIN FILHO, A. Absorção da área foliar sadia (HAA): uma nova abordagem para a quantificação de dano e para o manejo integrado de doenças. Summa Phytopathologica, v.20, n.3-4, p.134-151, 1994.

MADDEN, L. V. Measuring and modeling crop losses at field level. Phytopathology, v.73, p.1591-1596, 1983.

MADDEN, L.V.; NUTTER JR., F.W. Modeling crop losses at the field scale. Canadian Journal of Plant Pathology, v.17, p.124-137, 1995.

MADEIRA, A.C.; CLARK, J.A.; ROSSAL, S. Growth, light interception and disease in field bean (Vicia faba): the effect of late infection by Ascochyta fabae. Annals of Applied Biology, v.112, p.585-595, 1988.

MAUDE, R.B. Results in practice - III vegetable crops. In: MARSH, R.W.; (Ed.) Systemic Fungicides. New York: Longman, 1977. p.260. 
MENTEN, J.O.M.; MORAES, M.H.D.; CASTELANI, R.F.; PARADELA, A.L.; FAZARO, J.B.; GONELLA, L.G.R.; LEITE, O.M.C. Comparação de fungicidas no tratamento de sementes de feijão. In: CONGRESSO BRASILEIRO DE FITOPATOLOGIA, 29., Campo Grande, 1996. Fitopatologia Brasileira; resumos. Brasilia: SBF, 1996. p.402.

MICHAELS, T.E. The Bean Plant. In: HALL, R. (Ed.) Compendium of bean disease. St. Paul: The American Phytopathological Society, 1994. p. 1-4.

MIGLIORANZA, E. Modelo matemático-fisiológico para simular o crescimento e a produtividade da cultura do feijão (Phaseolus vulgaris L.). Viçosa, 1992. 184p. Dissertação (Mestrado) - Universidade Federal de Viçosa

MOHAN, S.K.; BIANCHINI, A.; MENEZES, J.R. de . Orientação para o controle de doenças do feijoeiro no Estado do Paraná. Londrina: Instituto Agronômico do Paraná, 1981. 12p. (IAPAR. Informe de Pesquisa, 39).

MONTEITH, J.L. Climate and the efficiency of crop production in Britain. Philosophical Transactions of the Royal Society of London, v. 281, p.277-294, 1977.

MONTEITH, J.L.; UNSWORTH, M. Principles of environmental physics. New York:Arnold, $1990.130 \mathrm{p}$.

MUNFORD, J.D.; NORTON, G.A. Economics of integrated pest control. In: TENG, P.S. (Ed.) Crop loss assessment and pest management. St Paul: The American Phytopathological Society, 1987. p.191-200.

NATIONAL ACADEMY SCIENCES. Insect pest management and control. Washington, 1969. 59 p. (NAS. Publication, 1965). 
NAVARRO, R.; PUERTA, O.D. Respuesta del frijol cargamanto a densidades de siembras y control químico de enfermidades. Phytopathology, v.73, p.123-124, 1983.

NILSSON, H.E. Application of remote sensing and image analysis at macroscopic and microscopic levels in plant pathology. In: TENG, P. S.; KRUPA, S. V. (Ed.). Crop loss assessment. St Paul: University of Minnesota. 1980. p.77-84.

NILSSON, H.E. Remote sensing and image analysis in plant pathology. Annual Review of Phytopathology, v.15, p.489-527, 1995.

NUNES, W.M.C.; BERGAMIN FILHO, A. Avaliação de danos causados pela antracnose (Colletotrichum lindemuthianum) do feijoeiro. Fitopatologia Brasileira, v.21, n.4, p.436-442, 1996.

NUTTER JR., F.W. Detection and measurement of plant disease gradients in peanut with a multispectral radiometer. Phytopathology, v.79, p.958-963, 1989.

NUTTER JR., F.W.; CUNFER, B.M. Quantification of barley yield losses caused by Rhyncosporium secalis using visual versus remote sensing assesment methods. Phytopathology, v.78, p.1530-1531, 1988.

NUTTER JR., F.W.; LITTRELL, R.H. Relationships between defoliation, canopy reflectance and pod yield in peanut late leaf spot pathosystem. Crop Protection, v.15, n.2, p.135-142, 1996.

NUTTER JR., F.W.; LITTERL, R.H.; BRENNEMAN, T.B. Utilization of a multispectral radiometer to evaluate fungicide efficacy to control late leaf spot in peanut. Phytopathology, v.80, p.102-108, 1990.

PARANÁ. Secretaria de Agricultura, Departamento de Economia Rural, 1995. Acompanhamento da situação agropecuária no Paraná, v.21, p.1-79. 
PARK, S.J.; BUZZELL, R.I.; TU, J.C. A resistant gene for Delta race of Colletotrichum lindemuthianum in NEP-2 bean. Annual Report of the Bean Improvement Cooperative, v.25, p.40-41, 1982.

PATAKY, J.K.; BEUTE, M.K.; WYNNE, J.C.; CARLSON, G.A. A critical-point yield model for Cylindrocladium black rot of peanut. Phytopathology, v.73, p.1559-1563, 1983.

PEDERSON, V.D.; FIECHTNER, G. A low-cost, compact data acquisition system for recording visible and infrared reflection from barley crops canopies. In: TENG, P. S.; KRUPA, S. V. (Ed.) Assesment of losses, which constrain production and crop improvement in agriculture and foresty. St. Paul: University of Minnesota, 1980. p.71-75.

PEDERSON, V.D.; GUDMESTAD, N. Evaluation of foliar diseases of barley with multispectral sensors. In: APS ANNUAL MEETING, 5., Minnesota, 1977. Phytopathology, resumos. St. Paul: The American Phytopathological Society, 1977. p.273.

RAHE, J.E.; KUC, J. Metabolic nature of the infection-limiting effect of heat on bean anthracnose. Phytopathology, v.60, p.1005-1009, 1970.

RAVA, C.A.; SATORATO, A.; BOTELHO, S.A. Eficiência in vitro e in vivo de fungicidas no controle de Colletotrichum lindemuthianum. Summa Phytopathologica, v.24, n.1, p.45-48, 1998.

RAWLINSON, C.J.; MUTHYALU, G.; CAYLEY, G.R. Fungicide effects on light leaf spot, canker, crop growth and yield of winter oil-seed rape. Journal of Agricultural Science, v.103, p.613-628, 1984. 
ROMIG, R. W. ; CALPOUZOS, L. The relationship between stem rust and loss in yield of spring wheat. Phytopathology, v.60, p.1801-1805, 1970.

ROTEM, J.; BASHI, E.; KRANZ, J. Studies of crop loss in potato blight caused by Phytophthora infestans. Plant Pathology, v.32, p.117-122, 1983a.

ROTEM, J.; KRANZ, J.; BASHI, E. Measurement of healthy and diseased halum area for assessing late blight epidemics in potatoes. Plant Pathology, v.32, p.109-115, $1983 \mathrm{~b}$.

SAH, D.N.; MACKENZIE, D.R. Methods of generating different levels of disease of disease epidemics in loss experiments. In: TENG, P.S. (Ed.). Crop loss assesment and pest management. St. Paul: The American Phytopathological Society, 1987. p.90-96.

SANDRES, J. H.; SCHWARTZ, H.F. Bean production and pest constraints in Latin America. In: SCHWARTZ, H.F; GALVEZ, G.E. Bean production problems: disease, insect, soil and climatic constraints of Phaseolus vulgaris. Cali: CIAT, 1980. p.3-14.

SARTORATO, A. Antracnose In: ZIMMERMANN, M.J. de O.; ROCHA, M.; YAMADA, T. (Ed.). Cultura do Feijoeiro: Fatores que afetam a produtividade. Piracicaba: Potafos, 1988. p.457-477.

SCHNEIDER, R.E.; WILLIAMS, R.J.; SINCLAIR, J.B. Cercospora leaf spot of cowpea: models for estimating yield loss. Phytopathology, v.66, p.384-388, 1976.

SCHULD, P. Auswirkung des befalls durch drei blattpathogene (Uromyces appendiculatus, Phaeoisariopsis griseola, und Colletotrichum lindemuthianum) 
auf das wachstum und den ertrag von phaseolus - Bohnen. Hannover, 1996. 215p. Thesis (Ph.D.) - Hannover Universität.

SCHWARTZ, H.F. Anthracnose In: HALL, R. (Ed.) Compendium of bean disease. St. Paul: The American Phytopathological Society, 1994. p.16-17.

SCHWARTZ, H.F.; PASTOR-CORRALES, M.A.; SINGH, S.P. New sources of resistance to anthracnose and angular leaf spot of beans. (Phaseolus vulgaris L.) Euphytica, v.31, p.741-754, 1982.

SHANDS, H.; VIEIRA,C.; ZAUMEYER, W.J. Observations on dry bean diseases in Brasil. Plant Disease Reporter, v.48, p.784-787, 1964.

SHANE, W.W.; TENG, P.S. Generating database for disease-loss modeling. In: TENG, P. S. (Ed.) Crop loss assesment and pest management. St. Paul: The American Phytopathological Society, 1987. p.82-89.

SHARP, E.L.; PERRY, C.R.; SCHAREN, A.L.; BOATWRIGHT, G.O.; SANDS, D. C.; LAUTENSCHLAGER, L.F.; YAHYAOUI, C.M.; RAVET, F.W. Monitoring cereal rust development with a spectral radiometer. Phytopathology, v.75, p.938$939,1985$.

STEADMAN, J.R. Documentation of use full bean (Phaseolus vulgaris) introductions. Annual Report of the Bean Improvement Cooperative, v. 17, p.81-83, 1974.

STERN, V.M.; SMTTH, R.F.; BOSCH, R. van den; HAGEN, K. S. The integrated control concept. Hilgardia, v.28, p.81-101, 1959.

TENG, P.S. Construction of predictive models: II. Forecasting crop losses. Advances in Plant Pathology, v.3, p.179-206, 1985 
TENG, P.S. Quantifying the relationship between disease intensity and yield loss. In: TENG, P.S. (Ed.). Crop loss assesment and pest management. St. Paul: The American Phytopathological Society, 1987. p.105-113.

THOMSON, WT Agricultural chemicals-fungicides. Fresno: Thomson Publications. 1973. 207p.

TRUTMANN, P.; GRAF, W. The impact of pathogens and arthropod pests on common bean production in Rwanda. International Journal of Pest Management, v.39, n.3, p. 328-333, 1993.

TU, J.C. Benomyl-resistant biotypes isolated from Delta race of Colletotrichum lindemuthianum. Annual Report of the Bean Improvement Cooperative, v.23, p.17-18, 1980.

VANDERPLANK, J. E. Plant diseases: epidemics and control. New York: Academic Press, 1963. 344p.

VETTORAZZI, C.A. Sensoriamento remoto orbital. Piracicaba: ESALQ Departamento de Engenharia Rural, 1992. 134 p. (Didática, 2).

VIEIRA, J.L.T.M. Produção e comercialização no Brasil. In; ZIMMERMANN, M.J. de O.; ROCHA, M.; YAMADA, T. Cultura do Feijoeiro: fatores que afetam a produtividade. Piracicaba: Potafos, 1988. p.21-35.

WAGGONER, P.E.; BERGER, R.D. Defoliation, disease and growth. Phytopathology, v.77, p.393-398, 1987.

WALKER, J.C. Diseases of bean and lima bean. In: WALKER, J.C (Ed.). Diseases of vegetable crops. New York: McGraw Hill, 1952. p.10-56. 
WATSON, D.J. Comparative physiological studies on the growth of field crops. I. Variation in net assimilation rate and leaf area between species and varieties, and within and between years. Annals of Botany, v.11, p.41-76, 1947.

ZADOKS, J.C. On the conceptual basis of crop loss assesment: the threshold theory. Annual Review of Phytopathology, v.23, p.455-473, 1985.

ZADOKS, J.C.; SCHEIN, R.D. Epidemiology and plant disease management. Oxford: University Press, 1979. 427p.

ZAMBOLIM, L.; CHAVES, G.M. Doenças do feijoeiro e seu controle. Informe Agropecuário, v.4, p.50-63, 1978.

ZAUMEYER, W.J.; THOMAS, H.R. A monographic study of bean disease and methods for their control. Washington: USDA, 1957. 15p. (Technical Bulletin, $868)$. 